\title{
Chapter 4 \\ Knowledge in Political Negotiations. \\ Three Diplomatic Encounters
}

\section{Introduction}

Es genügt nicht, daß derjenige Beamte der die Interessen seiner Behörde vor den Beamten des fremden Staates zu vertreten hat, die fremde Sprache kennt, sie in gewöhnlichen Verkehr mündlich und schriftlich anzuwenden weiss, sondern er soll im Stande sein - letztes Ziel! - sich vor den Mächtigen der Erde geschickt und ohne Fehl auszudrücken und zu benehmen, und in Konferenzen nicht zurückzustehen hinter denjenigen, denen die Konferenzsprache Muttersprache ist. ${ }^{1}$

On the twenty-fifth anniversary of the Seminar für Orientalische Sprachen (SOS) in 1912, its director Eduard Sachau drew up a linguistically and culturally adroit official, able to stand on his own and fend for German interests on the global stage. The appropriate education of German diplomats for their service in the extra-European world continued to be the SOS' most prominent task. The seminar's former teacher Friedrich Rosen was a forerunner of the envisioned culturally versed German diplomat. ${ }^{2}$ This chapter investigates the role applied cultural knowledge of the type necessary for conferences, trade, international law and in front of "the powerful" played during the time of expanding German imperialism in three sets of political negotiations that involved Rosen, both from the German perspective and from that of its counterparts.

In the spring of 1902 the Persian Shah Mozaffar ed-Din went on a several months long journey through Europe, finding reception at the royal courts of

1 "It does not suffice, that the official, who has to represent the interests of his government agency to the officials of a foreign state, knows the foreign language and how to apply it in common communication orally and in writing, but he shall be able - last goal! - to express and conduct himself deftly and without fault when facing the powerful of this earth, and not stand back in conferences behind those for whom the conference language is their native tongue." Sachau, Seminar für Orientalische Sprachen, 10.

2 There is of yet no comprehensive study of the SOS, its functions, output, staff and changing fortunes between academia, politics, trade and colonialism over the longue duree of its existence. Mangold, "Weltbürgerliche Wissenschaft", 227-50; Mangold-Will, Begrenzte Freundschaft, 187-92; L. Hanisch, Nachfolger der Exegeten, 40 - 45; Marchand, German Orientalism, 350 - 57; Burchardt, "School of Oriental Languages”; Larissa Schmid, "Competing Visions of Area Studies in the Interwar Period: The School of Oriental Languages in Berlin,” Middle East - Topics and Arguments 4 (2015): 127-37.

Ә OpenAccess. ( 2020 Friedrich Rosen, published by De Gruyter. (cc) BY-ND This work is licensed under the Creative Commons Attribution-NoDerivatives 4.0 License.

https://doi.org/10.1515/9783110639544-006 
St. Petersburg, Rome, Paris and London. He also spent three days in Berlin and Potsdam. During the Shah's visit to Germany Rosen was attached to his retinue and acted as interpreter in conversations with the Kaiser and at formal occasions. ${ }^{3}$ In the first months of 1905 Rosen led a mission to Addis Ababa to establish diplomatic relations between Germany and Ethiopia and negotiate terms of a treaty of friendship and trade with Ethiopian Emperor Menelik II. ${ }^{4}$ In the fall of 1906 Rosen travelled with a large entourage from Tangier to Fez to meet with Sultan Mulai 'Abd al'Aziz IV in a show of German support for the embattled Sultan and to push for German interests in Morocco. ${ }^{5}$

Each instance of negotiations is described in its respective context, Rosen's understanding and cultural ability is situated and the relevance of socio-cultural understanding is analysed. Cultures as distinct categories are understood as non-essential, constructed and changing, and here analytically employed as ideal-types following Max Weber. " $[$ E]ach culture is a unique complex of attributes subsuming every area of social life" Cohen notes in his analysis of twentieth century diplomacy in Negotiation across Cultures, which argues that “[u]nencumbered discourse... rests on the interlocutors' possession of a complex and extensive body of shared knowledge, conscious and unconscious, of what is right and fitting in human communication and contact. When this knowledge is absent, inadvertent confusion may result." With Rosen shaped by his various interactions in different cultural and political contexts, and following on the observation of Motadel that the Shahs' visits to Europe were in part motivated by the desire to understand the foreign, these political interactions are also understood as processes of learning and acculturation. ${ }^{8}$ The following questions are

3 Motadel showed how that the visits of the Iranian shahs served the purpose of learning about Europe and strengthening sovereignty through dynastic recognition. David Motadel, "Qajar Shahs in Imperial Germany," Past \& Present 213 (November 2011): 191-235.

4 Daum analyses Rosen as a skilled diplomat and power broker, Zitelmann Rosen's orchestration of the Aksum expedition under Enno Littmann, and Zimen provides a general overview of the Rosen mission. Tafla deals with the episode in his larger study on German-Ethiopian diplomatic relations. Daum, "Rosen, Littmann, Aksum"; Zitelmann, "Politische Einbettung der Aksum-Expedition”; Zimen, Rosen für den Negus; Tafla, Ethiopia and Germany.

5 Mangold-Will analyses Rosen's claim in his memoirs that he had to travel slowly to the Sultan in Fez, as this constituted the mode of travel of an Oriental grandee, and if this was a case of essentialising. In his study of the German colony in Morocco Mai mentions the episode in passing. Mangold, "Oriental Slowness”; Mai, Marokko-Deutsche, 319-27.

6 Max Weber, Wirtschaft und Gesellschaft. Grundriss der verstehenden Soziologie (Frankfurt: Zweitausendeins, 2005), 4.

7 Raymond Cohen, Negotiating Across Cultures. International Communication in an Interdependent World (Washington: United States Institute of Peace, 2002), 11-18.

8 Motadel, "Qajar Shahs in Imperial Germany," 193-94. 
investigated: how did socio-political and cultural knowledge deliver in the pursuit of interests, influence and power? In how far was culture and cultural difference a significant factor in political interactions? Could differences and perceptions of differences be mediated or bridged by multilingual and transcultural actors? How did actors learn during and along such political interaction? What was the role of such cultural understanding of the political interlocutor amid asymmetrical power relations? An analysis of these three instances of negotiations in their political and situational contexts and before the background of Rosen's expertise shows that cultural knowledge in the sense of the SOS had significant effects on the symbolic level of political prestige and equally facilitated non-crucial political collaboration. Vital political matters such as finances, or military aid, were, however, left mostly unaffected, as larger forces of power prevailed in bilateral and international relations.

\section{Cultural Knowledge and Political Leeway between Royal Courts. Mozaffar ed-Din Shah's Visit to Germany in 1902}

When Rosen started working on the Orient desk in the Auswärtiges Amt in early 1901, little had changed in German-Iranian relations from when he was last in Iran in 1899. The German legation in Tehran was still a minor player crunched between the Russian and British missions. Even Belgium and the United States had become more involved, soon outdoing Germany in influencing Iranian affairs. Germany had been offered a banking concession on the unauthorised instigation of chargé d'affaires Ferdinand von und zu Bodmann in 1897, but forwent the overture as German banks were not interested and the German government was reluctant to insert itself into the Russo-British scramble. The most notable change had been the 1899 establishment of the German consulate at Bushehr in the Persian Gulf to facilitate direct German exports via ship. But as irritating as the German consulate on the Gulf was to the British, German trade remained negligible. ${ }^{9}$

After taking over from his assassinated father in 1896, the new Iranian Shah, Mozaffar ed-Din, had started out as a reformer. He shook up his government, expelled his father's long-standing Sadr Azam Amin as-Sultan and brought in the

9 Wilhelm Litten, Persien. Von der "pénétration pacifique" zum "Protektorat". Urkunden und Tatsachen zur Geschichte der europäischen "pénétration pacifique” in Persien 1860-1919 (Berlin: De Gruyter, 1920), 217; Martin, German-Persian Diplomatic Relations, 62. 
reformer Amin ed-Dowleh and the military commander 'Abd-al Hosayn Mirza Farmanfarma - both leaning towards Britain. Farmanfarma had signalled in 1897 to Rosen that Iran would be interested in purchasing weaponry from the German steel-magnate Krupp, but such overtures were rejected by German diplomats and ultimately by the Krupp company itself. ${ }^{10}$ With reform efforts faltering quickly, the more Russia-reliant Amin as-Sultan was re-installed at the helm of the government and by 1900 Iran took on a major loan from Russia in exchange for a railway concession in the north of the country, cementing Russian preponderance in Iranian affairs. ${ }^{11}$ In the same year, a potential extension of the Baghdad railway via the caravan route at Khaneqin and Hamadan was contemplated by Germany. Britain was initially not opposed to involving Germany more in the region as a cost-efficient way to bolster the buffer states between its possessions in India and its northern rival. But the Russian press grew concerned with German political designs and Germany dropped its Iranian railway plans. ${ }^{12}$

Like his father Naser ed-Din Shah, who had travelled across Europe in 1873, 1878 and 1889 to conclude treaties, shore up his reputation with European rulers and learn about the latest developments in Europe, Mozaffar ed-Din also travelled north-west in 1900, 1902 and 1905. Naser ed-Din had been received by Bismarck in 1873 but during later visits Bismarck skipped meeting the Shah to avoid upsetting Russia. By the turn of the century, German global interests increased and as Motadel observes "an attitude of imperial superiority and rudeness" set in under Wilhelm II. When Mozaffar ed-Din crisscrossed the continent in 1900 the German leadership refused to meet the Shah. ${ }^{13}$

10 Martin, German-Persian Diplomatic Relations, 64-65; Cyrus Mir and EIr, "Farmānfarmā, 'Abd-al-Ḥosayn Mīrzā,” Encyclopædia Iranica, 15 December 1999. http://www.iranicaonline. org/articles/farmanfarma-abd-al-hosayn-mirza.

11 Calmard, "Atābak-e A’Ẓam, Amīn-al-Solțān”; Kazemzadeh, Russia and Britain in Persia, 305-15.

12 Spurred by calls among the colonialist Alldeutsche for German colonies along the Baghdad railway, the prospect of its extension into Iran was talked up by British diplomats and the press. Richard von Kühlmann to Bernhard von Bülow, 21 January 1902, A 6, R 19088, PA AA; Yate, "The Railway Race to the Persian Gulf I"; Robinson, "The Railway Race to the Persian Gulf II"; "Deutschland in Persien"; "Deutsche Interessen in Persien"; Kochwasser, "Bagdad-Bahn," 326; Johannes Lepsius, Albrecht Mendelssohn Bartholdy, and Friedrich Thimme, Weltpolitische Rivalitäten, Die Große Politik. (Berlin: Deutsche Verlagsgesellschaft für Politik und Geschichte, 1924), 512; Fuhrmann, "Deutschlands Abenteuer im Orient," 15; Hilmar Kaiser, "German Railway Investment in the Ottoman Empire: The Colonial Dimension," in Türkisch-Deutsche Beziehungen. Perspektiven aus Vergangenheit und Gegenwart, Claus Schöning, Ramazan Çalık, and Hatice Bayraktar (Berlin: Klaus Schwarz, 2012), 154-70.

13 Motadel, “Qajar Shahs in Imperial Germany,” 206-8. 
In the fall of 1901 the Iranian government once more announced that the Shah would travel to Europe. First Russia declared that it would accord the Shah every honour, then Great Britain extended a royal invitation, and also the Italian king agreed to receive the Shah. With the Shah's visit welcomed elsewhere in Europe, in early February 1902 the Iranian envoy to Berlin, Mirza Mahmud Khan Qajar Ehtesham es-Saltaneh, asked the German government to receive the Shah. The Iranian government hoped to improve "relations of personal friendship" between the Shah and the Kaiser. "One of the main reasons for the European tour was apparently to be received by the kaiser", as Motadel noted. ${ }^{14}$ In the mind of the Kaiser, however, there was no reason to meet the Shah. As Rosen recounted, the Kaiser believed the Iranians to be completely controlled by Russia, rendering a meeting superfluous. Widely read German diplomatic reports from Tehran described the "shiftlessness and weak-mindedness of the Shah", on which the Kaiser commented: "A ripe fruit! Who will pick it!" The Kaiser had heard rumours - Rosen thought those "ridiculous anecdotes" - that the previous visits of Naser ed-Din Shah had been awkward and embarrassing. ${ }^{15}$

What had changed since the previous trip of the Shah two years earlier was an economic downturn in Germany, which the German government intended to counter by increasing exports. In a speech to the Reichstag on 8 January 1902, chancellor Bernhard von Bülow had geographically outlined where Germany saw its future sales markets, as an arch spanning from East Asia to North Africa. Diplomatic circles in Tehran were quick to note that Iran also figured. ${ }^{16}$ In line with the new policy the chancellery tried to convince the Kaiser that Germany had economic interests in Iran - the Kaiser dismissed them as irrelevant. Eventually, in a concerted effort of the chancellery and the German envoy in Tehran, Arthur von Rex, who weighed in that his position would suffer from the insult of a German rejection, an arrangement was proposed under which the Shah would be received in Germany - in another snub - at the same time as the crown prince

14 Mahmud Khan Qajar Ehtesham es-Saltaneh to Oswald von Richthofen, 20 February 1902, 109, R 131735, PA AA; “Die neue persische Anleihe," Hamburgischer Correspondent, 22 February 1902; "Die Lage in Persien," Hamburgischer Correspondent, 19 February 1902; Motadel, "Qajar Shahs in Imperial Germany,” 208.

15 Friedrich Rosen, Unterlagen u. Beiträge betr. Reichsminister u. Diplomat Friedrich Rosen (†1935) - Besuch Schah Muzaffar eddin 1902, 1920s, 1 NL Müller-Werth 1199/34, HHStAW; Lepsius, Mendelssohn Bartholdy, and Thimme, Weltpolitische Rivalitäten, 518.

16 Richard von Kühlmann to Bernhard von Bülow, 21 January 1902, A 6, R 19088, PA. 
of Siam. ${ }^{17}$ In early March the newspapers reported that the Shah was expected to arrive in Berlin on 29 May 1902 from Italy, and leave for France four days later. ${ }^{18}$

At the time busy with estimating how Russo-British relations would be affected by the death of the long-ruling Emir Abdur Rahman Khan of Afghanistan in late 1901, a sweltering conflict between the Ottomans and the Greeks over Macedonia, and a developing low-level conflict between Germany and Britain over a potential end point of the Baghdad railway in Kuwait, Rosen's name does not appear in the diplomatic papers surrounding the issuance of the German invitation or the preparations of the Shah's German stay until early May. ${ }^{19}$ But he was aware of the preparations on the German and on the Iranian side. On 2 May the Persian envoy Ehtesham es-Saltaneh - a neighbour of Rosen in the Hildebrand Straße near Tiergarten and acquaintance from Tehran - requested from the Auswärtiges Amt that Rosen should be attached to the Shah for the duration of his trip in Germany. Rosen "mastered Persian" and enjoyed "personal relations with members of the retinue of the Shah, particularly the grandvezir [Amin as-Sultan]", making such an attachment desirable. ${ }^{20}$ The grey eminence at the Auswärtiges Amt, Friedrich von Holstein, inquired with the Kaiser's court if this arrangement would meet approval on the same day, but did not elicit a reply. Well on its way across Europe, the Shah's retinue once again wrote to the Auswärtiges Amt on 22 May, repeating the request and adding that Rosen should act as interpreter in conversations between the Kaiser and the Shah. This request was then approved by the Kaiser personally. ${ }^{21}$ Rosen speculated that Rex had intervened again to prevent another "act of tactlessness” against the Iranians. Rosen had briefly worked under Rex in Tehran in

17 Bernhard von Bülow to Wilhelm II, 23 February 1902, I 4593, R 131735, PA AA.

18 Norddeutsche Allgemeine Zeitung, 1 March 1902; Voyage de S.M.J le Schah, March 1902, I 8140, R 131735, PA AA.

19 Friedrich Rosen to Richard von Kühlmann, 19 March 1902, A 4380, R 19058, PA AA; Johannes Lepsius, Albrecht Mendelssohn Bartholdy, and Friedrich Thimme, Zweibund und Dreibund 1900-1904, Die große Politik. (Berlin: Deutsche Verlagsgesellschaft für Politik und Geschichte, 1924), 157; Johannes Lepsius, Albrecht Mendelssohn Bartholdy, and Friedrich Thimme, Die Wendung im deutsch-englischen Verhältnis, Die große Politik. (Berlin: Deutsche Verlagsgesellschaft für Politik und Geschichte, 1924), 496-512.

20 Oswald von Richthofen, Note, 2 May 1902, I 11250, R 131735, PA AA; Friedrich Rosen, Aus einem diplomatischen Wanderleben. Ende des Kaiserreichs. Weimarer Republik, Herbert MüllerWerth (Wiesbaden: Limes, 1959), 61; Mehrdad Amanat, “Eḥtešām-al-Salțana,” Encyclopædia Iranica VIII, no. 3 (2003): 269-71.

21 Friedrich von Holstein to Heinrich von Tschirschky, 2 May 1902, I 11250, R 131735, PA AA; Heinrich von Tschirschky to Otto von Mühlberg, 24 May 1902, I 13230, R 131735, PA AA; Heinrich von Tschirschky to Otto von Mühlberg, 23 May 1902, I 13230, R 131735, PA AA. 
the winter of 1898/9 and thought little of his former chief, "who exceeded all his predecessors in foolishness and lack of sensitivity". There was no other way, Rex had it, "the Persians saw a friend in Rosen". 22

The in Iran "nearly almighty" Amin as-Sultan counted on Rosen to make the Shah's and his own visit to Germany a success. ${ }^{23}$ As the Iranian government became more and more reliant on Russian finances and was equally distrustful of British machinations, another effort at drawing in Germany was Amin as-Sultan's best option at preserving what was left of the country's integrity. Iran's quagmire was clear to German diplomacy. The German envoy to Italy, Karl von Wedel, wrote to Berlin, after talking with the Shah at a reception in Rome, that he believed that the ruler sought to preserve "his Persian independence and his freedom" and that his visit to Berlin was motivated by the belief that this desire would be understood in Germany. Wedel also noted that the Shah feared for his life and constantly carried a loaded gun in his pocket. ${ }^{24}$ Intrigues at the Iranian court were ongoing and had in the previous fall led to a botched coup against Amin as-Sultan, who stood accused of selling the country out to the Russians. The conspiring officials were removed. Among them was the previous Iranian envoy in Berlin, who was replaced by Ehtesham es-Saltaneh, loyal to Amin as-Sultan and friend of the German official responsible for Iran. ${ }^{25}$ As Mozaffar ed-Din and his several hundred strong entourage - Rosen reckoned many court members had to come along as they otherwise might have conspired against the Shah or the Sadr Azam at home - made their way from Rome through Switzerland to the German border, Rosen travelled by special train to Basel in the company of General Viktor von Lignitz, Major Lothar von Trotha and Ethesham es-Saltaneh to receive the Shah. ${ }^{26}$ Lignitz and Trotha were added on to the welcoming committee at the last minute and had during the three days only a decorative role. It stands to reason that the so explicitly requested friend of the Iranians should not be left all alone with the Shah's party.

The Shah, who had made a stop in Lucerne to buy camera equipment that would "kick off Persia's adventure in cinematography", was glad to meet the Ger-

22 Friedrich Rosen, Besuch Schah Muzaffar eddin, 1920s, 1 NL Müller-Werth 1199/34, HHStAW; Friedrich Rosen, 1926, Hinterlassene Manuskripte I, 6 NL Müller-Werth, PA AA, 49, 74.

23 Richard von Kühlmann, Suite de S.M.J. le Schah, 7 April 1902, I 10122.02, R 131735, PA AA. 24 The Italian king had told Wedel about the gun. Karl von Wedel to Bernhard von Bülow, 24 May 1902, R 19075, PA AA.

25 Calmard, “Atābak-e A’Ẓam, Amīn-al-Solțān”; Friedrich Rosen, Note, 1 September 1901, A 12651, R 19082, PA AA; Mehrdad Amanat, "Eḥtešām-al-Salțana.”

26 Heinrich von Tschirschky to Mahmud Khan Qajar Ehtesham es-Saltaneh, 25 May 1902, I 13318, R 131735, PA AA. 
mans in Basel on 27 May. The two German generals made an impression, and Mozaffar ed-Din remembered that he had met Rosen, the "deputy" of the German foreign minister, before in Tehran. He was a "very good person". ${ }^{27}$ Apart from conversing with the Shah, Rosen had to carry out symbolic and substantial tasks en route to Berlin. Just like the Iranians, who arrived with boxes full of medals to be awarded to German officials, the German ceremonial masters had compiled several page-long lists of the Iranian officials participating in the journey, which rank they held at the Iranian court, how much power they exerted and how they positioned themselves towards Germany. Another matter important for the accurate decoration was whether German honours had been bestowed on the Iranian officials in the past and which medals other European states awarded to them. ${ }^{28}$

There was nothing culturally specific to the exchange of gifts or decorations, but the practice of awarding medals had been adopted by the Qajar rulers in the early nineteenth century as diplomatic interactions with European states increased. ${ }^{29}$ This gift-making was important, as the rank of one order or the other signified the stature of the endowed official. Honours were often publicly announced and diplomatic staffs of the various countries exchanged such information as markers of diplomatic relations. The higher up the decorated official was placed the more symbolically significant was the honour received for the quality of the relations of the two medal-exchanging countries.

In the case of the embattled Iran, this symbolism also expressed an assignment of international sovereignty and could have ramifications on a ruler's or minister's internal legitimacy. Accurate decoration was an important matter and Rosen returned to the issue of honouring the Persian guests repeatedly throughout the visit. While the Shah's train rattled to Berlin last corrections were made. There had been uncertainty as to what medal the Shah's Sadr Azam Amin as-Sultan should receive. Rosen wired that Amin as-Sultan had, just like the Shah, received the Annunciation medal in Rome, but the first class Roter Adler Orden that would have been appropriate turned out to have already been awarded during the 1889 visit. Eventually, he received the first class Kronenorden. ${ }^{30}$

27 [Mozaffar ed-Din Shah], Duvvumin Safarnama-yi Muzaffar al-Din Shah bih Farang [in Persian] (Tehran: Kavush, 1982), 54; Jalali, Erani in Berlin, 36.

28 Decorations Lists, July 1902, Abtheilung I B, PA AA; Motadel, "Qajar Shahs in Imperial Germany,” 213.

29 Motadel, "Qajar Shahs in Imperial Germany,” 217.

30 Deutscher Reichs-Anzeiger und Königlich Preußischer Staats-Anzeiger 209 (5 September 1902); Friedrich Rosen to AA, 28 May 1902, I 13749, R 131735, PA AA; Wilhelm II and Bernhard von 
This symbolic German effort stood in marked contrast to the handling of these ceremonies in London later that summer. The British envoy to Tehran, Arthur Hardinge, who battled for Britain's influence in the country and had been conspiring with Amin as-Sultan's opponents to topple the Sadr Azam, had in a sign of non-confidence let the Germans know in advance that the Persians were not going to receive any medals in London, but would merely be awarded other gifts, such as pictures. This lack of symbolic decoration was a planned insult, which the Shah understood as such. He had expected to be awarded the highest order of British knighthood, but he was denied the Order of the Garter on account of being a Muslim. This provoked a scene at the British court. When the Shah protested against the slight, he was told that the Ottoman Sultan had not received the Order of the Garter either. The Shah retorted that he had also not massacred the Armenians but given them shelter. The German representatives in Iran understood this as a failure in Hardinge's planning. ${ }^{31}$ However, the scandal was intended as a brusque dressing-down of the Iranians for having joined the side of Russia and at the same time sought to demonstrate to worried Russia that Britain was not pursuing a closer relationship with the Shah. The goal was to weaken the Shah and his government. ${ }^{32}$ In contrast, German observance of ceremonial protocol, not least because of Rosen's interventions, signalled friendlier motives.

From Mulhouse Rosen wired Berlin that the Shah had expressed his wish to visit - like his father - the factories of Krupp in Essen. The Shah asked that a visit should be combined with meeting the owner on his onward journey from Berlin to France. Rosen had been involved in Iranian military requests in the 1890s and had translated Naser ed-Din Shah's 1873 descriptions of Germany, including his visit to Essen. He knew that the stop in Essen was not supposed to be merely an informative visit. ${ }^{33}$ The German government did not shut down the request, but forwarded it without much comment to Krupp, who conveniently an-

Bülow, Note, 30 May 1902, 36013, R 131735, PA AA; Friedrich Rosen to G.L. von Eichborn, 16 May 1902, 11606, R 131735, PA AA; Friedrich Rosen, Note, 1 June 1902, I 14181, R 131735, PA AA; Wilhelm II and Bernhard von Bülow, Note, 11 June 1902, I 15183, R 131735, PA AA.

31 von Kühlmann, Suite de S.M.J. le Schah; Calmard, "Atābak-e A’Ẓam, Amīn-al-Solțān”; Motadel, "Qajar Shahs in Imperial Germany,” 191; Arthur von Rex to Bernhard von Bülow, 20 November 1902, A 17278, R 19058, PA AA; Rose Greaves, "Iranian Relations with Great Britain and British India, 1798 - 1921," in The Cambridge History of Iran, Peter Avery, Gavin Hambly, and Charles Melville (Cambridge: Cambridge University Press, 1991), 414.

32 "England and Persia," The Levant Herald, 3 September 1902; "The Situation in Persia," The Globe, 15 August 1902.

33 Friedrich Rosen to AA, 28 May 1902, I 13749, R 131735, PA AA; Friedrich Rosen, Neupersischer Sprachführer, 144-45; Yorulmaz, Arming the Sultan, 318. 
swered that to his "deep regret a reception of his majesty was impossible" as the Krupp villa was under construction. The Shah could visit the factory, if he liked. ${ }^{34}$ The message was clear. A visit would not lead to the purchase of weapons and Essen did not make the itinerary of the Persians for its sights. ${ }^{35}$ What would have been a first defeat for the Iranian side was not linked as much to matters of culture or understanding, but to economic considerations of Krupp. The Shah's coffers were - despite a new loan of Russia - perennially empty and arms exports to Iran risky. That the request was made already en route to Berlin would have had to do with the presence of the arbiter Rosen, who portrayed sympathy for the Iranian side, but who could not single-handedly bring about a weapons sale without severely compromising his position in the Auswärtiges Amt.

The Shah arrived in the residence city of Potsdam on 29 May at 6 p.m. where he was greeted by the Kaiser. The two rulers boarded a carriage that followed half a regiment of the Kaiser's elite Gardes du Corps. They were flanked by members of the Kaiser's court on horseback and followed by the second half of the Gardes du Corps. The two thus sufficiently glorified regents were followed by four high placed German military figures and behind by Amin as-Sultan, the German state secretary Oswald von Richthofen, Ehtesham es-Saltaneh and Rosen. The Iranian envoy and the German Orient official were certainly on par, but it is noteworthy that the Persian prime minister was not met by chancellor Bernhard von Bülow, but only by the state secretary. ${ }^{36}$ During the short ride from the train station to Sanssouci Palace the two rulers would not have exchanged much more than pleasantries. Mozaffar ed-Din's French was limited and Rosen had advised that he should not talk with Wilhelm in French directly to avoid embarrassment. ${ }^{37}$ At Sanssouci the Shah and his entourage were welcomed at the Orangerie, where the Shah was housed, by a large guard of honour with the national anthem Salamat-i Shah playing and the Persian banner hoisted the time of the Shah's arrival. ${ }^{38}$ As Rosen noted, the Orangerie had been picked as an abode for the Shah, as it was thought that there the Iranians would not get the chance to "break too much".

34 Friedrich Alfred Krupp to Oswald von Richthofen, 29 May 1902, I 13801, R 131735, PA AA. 35 [Mozaffar ed-Din Shah], Duvvumin Safarnama.

36 Friedrich Rosen, Shumā Farsī härf mīzänīd (Sprechen Sie Persisch?): neupersischer Sprachführer, für die Reise und zum Selbstunterricht enthaltend eine kurze Grammatik, Wörtersammlung, Gespräche und Lesestücke (Berlin: Ferd. Dümmlers Verlagsbuchhandlung, 1925), 138.

37 Friedrich Rosen, Besuch Schah Muzaffar eddin, 1920s, 1 NL Müller-Werth 1199/34, HHStAW. 38 Programm für die Anwesenheit Seiner Majestät des Schah von Persien, 29 May 1902, I 13746, R 131735, PA AA. 
It was a warm spring day and the citrus trees were in full blossom, and while alighting from the carriage, the Kaiser explained to the Shah through Rosen's interpretation that he had him housed in the Orangerie because he had heard that Persians liked parks and gardens. The Kaiser reminisced that father Naser ed-Din had liked Potsdam's gardens and that Mozafar ed-Din should have a look around. The Shah replied that he did not need to explore the garden, "as the honourable and gracious reception that his royal highness the Kaiser had welcomed me with is for me park and garden”. Mozaffar's answer, in which Rosen perceived a reference to Sa'di's poetry, in an instant won over the Kaiser, who immediately began talking in similar pictorial language. "The magic of the Orient had seized him”, Rosen found with a sense of relief. ${ }^{39}$

Things were off to a good start between the two rulers. Rosen interpreted the speeches of the Shah and the Kaiser, in which the Kaiser thanked the Shah for his visit and expressed his pleasure in Iranian-German relations being at their best. The Shah responded by thanking the Kaiser for the friendly reception and expressing his wish that God saw Iranian-German relations strengthening even further, and raised his glass in a toast to the Kaiser - a departure from Iranian ceremonial. Rosen recorded both speeches, had the versions approved by Amin as-Sultan and sent them to the chancellery to keep Bülow informed. ${ }^{40}$ Shortly after, the Shah briefly visited the Kaiser at the Neues Palais, but ate by himself in the Orangerie that evening. Already in Rome the Shah had wanted to eat alone according to his "Asiatic manners", that is without cutlery, as the German envoy Wedel had reported. ${ }^{41}$ Although European-style banquets had been introduced in Iran under Mozaffar ed-Din, the practice of eating with hands while sitting on the ground came more naturally to the Shah. The next morning, Mozaffar ed-Din travelled by special train to Berlin to join the Kaiser in inspecting a military parade on the Tempelhofer Feld. The skies were clear and the Shah, whose health had been impaired for years, suffered from the heat and the dusty field. Against etiquette, Rosen organised a carafe of water to stabilise the Shah's perseverance. The following reception the Berlin Stadtschloss further fatigued the Shah, who asked Rosen why everyone was always standing. An "alte Hofsitte" (old etiquette of the court), Rosen explained. Moreover, the consumption of "Sekt und Säfte" (sparkling wines and juices) and the absence of water was odd to the Shah. ${ }^{42}$ Rosen and Amin as-Sultan, aware that

39 Friedrich Rosen, Besuch Schah Muzaffar eddin, 1920s, 1 NL Müller-Werth 1199/34, HHStAW.

40 Friedrich Rosen to Bernhard von Bülow, 30 May 1902, I 13988, R 131735, PA AA.

41 Programm für Schah von Persien, 29 May 1902, I 13746, R 131735, PA AA; Karl von Wedel to Bernhard von Bülow, 24 May 1902, R 19075, PA AA.

42 Programm für Schah von Persien, 29 May 1902, I 13746, R 131735, PA AA. 
more breaking of etiquette would be frowned upon, did their best to keep the Shah on course.

In another instance at the reception Rosen was concerned that his sovereign would stumble into a cultural faux-pas. The Kaiser was much enthused at the time by the research of Friedrich Delitzsch, who stipulated that Mosaic law originated in Babylonian scriptures, perceived Assyrian culture superior to that of the Old Testament and later thought Jesus to exhibit Aryan characteristics. On the occasion of the Shah's visit newspaper articles had elevated the Persians onto a common ground with Germany due to supposedly shared Aryan origins, and Wilhelm, who was interested in "finding a bridge, to comprehend the influence of the East on the West in cultural terms", mirrored this notion of kinship. Bringing up Delitzsch's studies, the Kaiser thought could interest the Shah due to the "territorial continuity" of ancient Babylon and modern Iran. ${ }^{43}$ Rosen was mostly concerned that the Kaiser would offend the "strictly Shi'ite Shah" with his talk of the unenlightened jahili past, but the Shah just listened politely. In a conversation with crown princess Luise about recent German Orientalist scholarship the Shah stood his ground, portraying civilised modernity in talking to a woman. ${ }^{44}$

The Shah did not express any further interest in the Hohenzollerns' obsessions with the ancient East and did not grab the opportunity of leveraging German interests for arranging an archaeological agreement. Rosen had known of archaeological deals the Iranian government had made with France in the 1890s, had personally met the French excavators of Susa, Jane and Marcel-Auguste Dieulafoy, in Paris in 1893 and knew of the political relevance an excavation treaty could carry. The Kaiser's interest in Delitzsch's research was wellknown and considering that Delitzsch had updated Rosen on his travels in the Ottoman Empire in the months before the visit of the Shah, the topic was not new to the Orient-man of the Auswärtiges Amt. ${ }^{45}$ That the topic came up in

43 Wilhelm II, Ereignisse und Gestalten aus den Jahren 1878-1918 (Wolfenbüttel: Melchior, 2008), 168; David Motadel, "Iran and the Aryan Myth," in Perceptions of Iran. History, Myths and Nationalism from Medieval Persia to the Islamic Republic, Ali M. Ansari (London: I.B. Tauris, 2014), 124; Suzanne Marchand, "German Orientalism and the Decline of the West," Proceedings of the American Philosophical Society 145, no. 4 (December 2001): 468-89.

44 [Mozaffar ed-Din Shah], Duvvumin Safarnama, 58; Friedrich Rosen, Besuch Schah Muzaffar eddin, 1920s, 1 NL Müller-Werth 1199/34, HHStAW.

45 Friedrich Delitzsch to Friedrich Rosen, 24 February 1902, 1901-5, ASWPC; Friedrich Delitzsch to Friedrich Rosen, 26 February 1902, 1901-5, ASWPC; Friedrich Rosen, 1926, Hinterlassene Manuskripte I, 6 NL Müller-Werth, PA AA, 84; Axel Heimsoth, "Die Bagdadbahn und die Archäologie. Wirtschaftliche und wissenschaftliche Planungen im Osmanischen Reich,” in 
the conversation between the Kaiser and the Shah at a gala dinner should thus not have surprised Rosen. As his estimation of the primacy of religious sensitivities shows, he had not counselled the Shah on the matter or any other potential archaeological undertakings. Whether he avoided this out of a misplaced religious sensitivity or simply did not want to offer the Persians a way of attracting German attention out of fear of upsetting the French who had gained an excavation monopoly in Persia in 1900, in this situation Rosen did not improve the Shah's hand. ${ }^{46}$

The opera performance, a mixture of Orientalist themes of Ä̈da and European motives such as Carmen, that evening the Shah left early as the air in the opera house was too stuffy. It is doubtful that Rosen could have arranged for a discreet departure of the Shah from an exposed balcony. The next day, 1 June, saw another parade and carriage ride in Potsdam with a further luncheon at the Neues Palais and a viewing of the different rooms. In the afternoon the Shah, a passionate hunter, went deer hunting with Rosen, who told him of his travels in northern India. The roebuck the Shah shot was taxidermied and taken back to Iran. ${ }^{47}$

Occupying the Shah with ceremonial, socialising and sight-seeing was reflective of the German government's hesitance of entering substantive talks on further cooperation. The Shah "teased the grand vezier, because he negotiated trade deals with the ministry" as he was visiting Berlin's zoo and aquarium. ${ }^{48}$ The Sadr Azam thought that the development of German interests in his country would countervail growing Russian influence. The British envoy Hardinge had shown himself "more incompetent" in balancing out Russian influence than his predecessors, and he hoped that the Germans would fill the void. No major trade deals were signed, but while the Shah was busy with entertainments, the conversations the Sadr Azam conducted at Wilhelmstrasse encouraged further German business engagement in Iran, as Rosen penned down in an internal note a month later. Prompted by the Iranian envoy Ehtesham es-Saltaneh, Rosen also informed the Auswärtiges Amt that the Shah had asked the Kaiser in a conversation to sell him twelve machine guns but Rosen's note was of as little consequence as had been the earlier entreaties of the Iran for

Das große Spiel. Archäologie und Politik zur Zeit des Kolonialismus (1860-1940), Charlotte Trümpler (Essen: Ruhr Museum, 2008), 363; Röhl, Der Weg in den Abgrund, 563.

46 Litten, Persien "pénétration pacifique”, 197; [Mozaffar ed-Din Shah], Duvvumin Safarnama, 57. 47 Programm für Schah von Persien, 29 May 1902, I 13746, R 131735, PA AA; Friedrich Rosen, Besuch Schah Muzaffar eddin, 1920s, 1 NL Müller-Werth 1199/34, HHStAW; [Mozaffar ed-Din Shah], Duvvumin Safarnama, 57.

48 Friedrich Rosen, Besuch Schah Muzaffar eddin, 1920s, 1 NL Müller-Werth 1199/34, HHStAW. 
weapons. Though smitten by the Oriental sovereign and his flowery language, Wilhelm saw no reason to become politically involved in the disintegrating state. Similarly, the German chancellery wanted to increase exports, and trade would in fact increase significantly in the following years, but neither Bülow nor Holstein had any interest in being drawn into Russia's and Britain's Iranian game. ${ }^{49}$

This limited interest also became apparent in the following months, as the journey of the Shah and his entourage continued across Europe. While the Shah was taking baths for his health in French Contrexéville, Rosen was contacted by the Iranain minister of public works Mukhbir es-Saltaneh - also part of the Persian travelling group - with the idea that the Shah would establish an iron ore factory in Tehran in order to industrialise Iran, allow for its own machinery production and thus become less reliant on expensive import. Rosen was asked if he could not bring together a group of German industrialists that would construct such an industry in Iran. To connect the factory to the grid, railway concessions would also be a possibility, Mukhbir es-Saltaneh noted. If the Germans were interested, an engineer should simply be sent to Contrexéville to talk over the details. Germany could have the railway concession right away. At the time on summer holidays in Belgium, Rosen forwarded the request to the Auswärtiges Amt, only noting that the absence of forests in the vicinity of Tehran and scarcity of wood would complicate railway constructions. ${ }^{50}$ Persian wooing again did not provoke German interest in closer involvement and Rosen did not become active in attracting German industrialists on his own.

Despite the shortfall in concrete results, the visit was perceived as successful by both sides. As Mozaffar ed-Din Shah crossed Germany again after a stay in the Carlsbad spa, he wired Wilhelm his thanks for "the cordial and kind reception that I found" which was now eternally engraved in his heart. The Kaiser replied that his visit to Potsdam "caused my veritable joy" and that also the empress fondly remembered him. In his continuing efforts to extend symbolic capital Rosen had recommended that the Kaiser should, if he intended to wish the Shah farewell, give as a courtesy his greetings to the Iranian crown prince. In following Rosen's advice, the Kaiser extended royal recognition to the Shah's son, which was in consideration of the Shah's weak health symbolically impor-

49 Friedrich Rosen, Note, 6 July 1902, A 10381, R 19088, PA AA; Heinrich von Tschirschky to German Embassies in London and St. Petersburg, 28 July 1906, A 112624, R 19088, PA AA; Litten, Persien "pénétration pacifique”, 217-22; Martin, German-Persian Diplomatic Relations, 61-62. 50 Friedrich Rosen, Auszug aus einem Briefe des Persischen Ministers Mukhbir es Saltane an W.L.R. Rosen, 25 July 1902, 11326, R 18984, PA AA. 


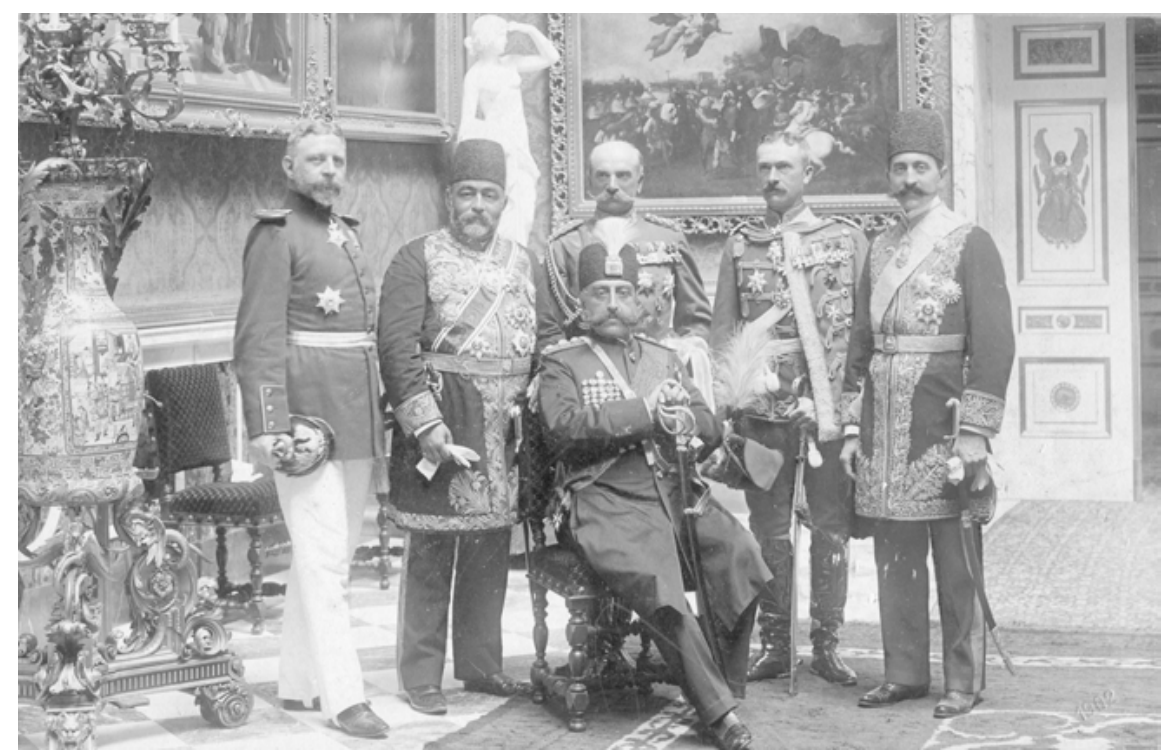

Fig. 4.1. Mozaffar ed-Din Shah in the Orangerie near Potsdam, May 1902. Standing behind the Shah from the right: Ehtesham es-Saltaneh, Lothar von Trotha, Viktor von Lignitz, Amin asSultan and Friedrich Rosen.

tant for the continuation of the Qajar dynasty. ${ }^{51}$ On the way back from England later that summer, the Shah crossed Germany one last time. The evening before arriving in Berlin, Ehtesham es-Saltaneh informed Rosen that the Shah would travel through the German capital incognito. Police protection was hastily arranged and Rosen and state secretary Richthofen went to the train station to exchange greetings one last time. Courtesies aside, the Iranians knew that they could not expect much more from the Germans. ${ }^{52}$

As Rosen continued dealing with issues surrounding the Baghdad railway, he had proven himself a reliable diplomat in the eyes of the Auswärtiges Amt, the chancellery and the Kaiser, whom he came to see more often in the following months. On the Iranian side, the visit to Germany brought mixed results. As Rex

51 Mozaffar ed-Din Shah to Wilhelm II, 8 June 1902, I 14411, R 131735, PA AA; Wilhelm II to Mozaffar Ed-Shah, 8 June 1902, I 14411, R 131735, PA AA; Friedrich Rosen, Note, 1 June 1902, I 14181, R 131735, PA AA; Friedrich Rosen to Bernhard von Bülow, 1 June 1902, I 14975, R 131735, PA AA. 52 Friedrich Rosen and Oswald von Richthofen to Heinrich von Tschirschky, 16 September 1902, A 13747, R 19075, PA AA; Oswald von Richthofen to Wilhelm II, 15 September 1902, I 24088, R 131735, PA AA; Mozaffar ed-Din Shah to Wilhelm II, 16 September 1902, A 13892, R 19075, PA AA; Friedrich Rosen, Note, 14 September 1902, I 23856, R 131735, PA AA. 
reported upon the Shah's arrival back in Tehran in November, the "highlight of this year's Shah-trip was the visit in Berlin". The Shah had been impressed by the gardens, display of German troops, and enjoyed the "graciousness" of the Kaiser. Britain, in contrast, had been a "bitter disappointment". ${ }^{53}$ Most significantly though, the trip had not led to the stabilisation of the country. Encouraging signals from Germany did not translate into any concrete commitments that could compensate British slack. Even the Dutch committed themselves more by sending an engineer to take over constructions of a dam on the Karun river. ${ }^{54}$ Nevertheless, the Iranians did not leave Germany entirely empty-handed. The royal visit had happened, which was a first victory, and there had been no embarrassing incidents to mention. The exchanges with the German regent were amiable, relations with the German government had been strengthened and press coverage had been positive. The care with which medals were exchanged and the greetings relayed to the crown prince were also a good sign for potential future exchanges. However, though signalling accommodation to German business interests, in practical terms Iran had not gained what it wanted. Requests to purchase weapons were nipped in the bud, mining and railway concessions were rejected, and a formal trade deal was also not concluded.

Whether Mozaffar ed-Din did not grasp the severity of his position, as Rosen suggested, or if the Shah was, as the archival documents show, in fact pursuing the survival of his dynasty and the integrity of his country to the best of his circumscribed abilities with the assistance of Amin as-Sultan, the international recognition he took back with him to Iran did not compensate for the cost of the trip or insulate his country from the further machinations of the British and Russian envoys in Tehran. The Shah had been received by Germany, but the Kaiser and the German government would not make a stance on the side of the Iranians. The trip had cost money, and soon it became clear that the majority of the twelve million ruble loan the Russians had given the Iranians just months before had been spent. Moreover, in his absence from Iran the British had further agitated against the Sadr Azam. When unrest spread in several Iranian cities in the summer of 1903, Rosen could read in the newspapers that his erstwhile partner Amin as-Sultan had been excommunicated by the "ulema and was shortly later dismissed. ${ }^{55}$ Germany on the other hand had received what it wanted: a friendly business environment in Iran. The visit had been painless to the Kaiser, in no small part because Rosen had proved to be a careful and trustworthy language

53 Arthur von Rex to Bernhard von Bülow, 20 November 1902, A 17278, R 19058, PA AA.

54 Litten, Persien "pénétration pacifique", 86-87.

55 Calmard, “Atābak-e A’Ẓam, Amīn-al-Solțān”; “Die Verfluchung des ehemaligen Sadrazam von Persien,” St. Petersburger Zeitung, 24 December 1903. 
and culture interpreter for both sides. The Kaiser even took a liking to the Iranian man he had not wanted to meet. A plethora of German officials from high up to low down could pin an exotic medal of a sun shining over a lion onto their waistcoats, and the public spectacle was equally successful.

The engagement of Rosen as an intermediary had been a sensible choice by the Iranians, but beyond facilitating a gain in symbolic currency, Rosen's abilities were either overestimated by the Iranians or they were clutching at straws, and Rosen was as good as it got. By channelling much of the high-level engagements through Rosen, Mozaffar ed-Din, Amin as-Sultan and Ehtesham es-Saltaneh had picked the most suitable person, who had demonstrated his goodwill in the past. Their inquiries with Rosen throughout the summer also show that Rosen was not perceived as detrimental to their mission. The Shah reiterated in his travel diary that Rosen was a "very good person" and spoke "Persian very well". ${ }^{56}$ Rosen's language abilities and background knowledge facilitated easy approach and conviviality. By maintaining his friendliness towards the Iranian interlocutors, he signalled that approaching him again and again would not hurt. However, Rosen either assigned a determining quality to the Shah's Muslim faith, or decided to withhold from the Shah for any number of reasons his knowledge about the political potential the Orientalist interests of the Kaiser could have for engaging Germany more forcefully in Iran and thus prop up the embattled Qajar court. In the matters of weapons and concessions Rosen carried out his duty of relaying requests, but did not exert himself beyond his means. Through the trust the Iranians placed in him, Rosen got the opportunity to demonstrate his ability and loyalty to his superiors. While there may have been an element of Rosen leading on his Iranian friends for his personal gain, his relations with his Iranian partners continued without strain. ${ }^{57}$ Considering what was at stake and how desperate the situation had become for Iran at the eve of the Constitutional Revolution in 1905, Mozaffar ed-Din Shah and his Sadr Azam Amin as-Sultan maximised their gains in Germany with the help of Rosen. Tragically, the most tangible prey they took back with them from Germany was a taxidermied roebuck.

56 [Mozaffar ed-Din Shah], Duvvumin Safarnama, 58.

57 Mozaffar ed-Din Shah to Friedrich Rosen, 1905, Zettelkiste, ASWPC; Heinrich von Tschirschky to AA, 26 August 1905, I 24088, R 131735, PA AA; Motadel, “Qajar Shahs in Imperial Germany," 210. 


\section{Application, Creation and Sharing of Knowledge. Establishing Diplomatic Relations with Emperor Menelik II of Ethiopia in 1905}

In the period 1871-1883, Ethiopian-German relations were characterised by Ethiopia seeking moral and diplomatic support from Germany and other European countries against Egyptian territorial encroachment "first on grounds of common religion and eventually on the basis of the so-called humanitarian policy of the European powers themselves." Emperor Yohannes IV (r. 1871-1889) had hoped that European control of the Red Sea would help him against his Muslim neighbours in Sudan and along the Somali coast, but his hopes were soon disappointed when the European powers excluded Ethiopia from weapons sales. ${ }^{58}$ The German government reacted evasively to Ethiopian overtures. A German mission led by the explorer Gerhard Rohlfs to the court of Yohannes did not result in political collaboration, despite Yohannes requesting Rohlfs to become his chief negotiator with Egypt. Germany saw no incentive to become involved in the Franco-English rivalry over the lands along the two Niles. ${ }^{59}$ When Germany, Italy and Austria-Hungary signed the Triple Alliance signed in 1882, Germany became even more hesitant towards Ethiopian overtures and favoured the establishment of an Italian protectorate over Ethiopia. ${ }^{60}$

After the death of Yohannes in 1889, the previous Ras (prince) Menelik II of the province of Shoa (Sheva) seized the Ethiopian throne. In his campaign for the throne Menelik had signed a treaty with the Italians at Wuchale, in which Ethiopia forewent claims in Eritrea and Italy in the Ethiopian highlands. The treaty came in Italian and Amharic versions. The Italian version included a passage that stipulated that all Ethiopian correspondence with the European powers

58 Tafla, Ethiopia and Germany, 76; Nicola Storti and G. Joseph Negoussie, "La missione umanitaria di Leone XIII presso Menelik II nel 1896, alla luce dei documenti Vaticani,” Africa: Rivista trimestrale di studi e documentazione dell'Istituto italiano perl'Africa e l'Oriente 40, no. 4 (December 1985): 542-76; Wolbert G.C. Smidt, "British Colonialism in the Horn of Africa," in Encyclopaedia Aethiopica. A Reference Work on the Horn of Africa, vol. 5, Siegbert Uhlig and Alessandro Bausi (Wiesbaden: Harrassowitz, 2010), 1028.

59 Yohannes IV to Wilhelm I, 10 August 1872, A 3021, R 14885, PA AA; Gerhard Rohlfs, Meine Mission nach Abessinien. Auf Befehl Sr. Maj. des deutschen Kaisers im Winter 1880/81 unternommen (Leipzig: F.A. Brockhaus, 1883); Bairu Tafla, "Rohlfs, Gerhard," in Encyclopaedia Aethiopica. A Reference Work on the Horn of Africa, vol. 4, Siegbert Uhlig and Alessandro Bausi (Wiesbaden: Harrassowitz, 2010), 408.

60 Tafla, Ethiopia and Germany, 75. 
would henceforth have to be relayed via Italy. By handing over its channels of communication, Ethiopia had without its own knowledge become in the eyes of European governments an Italian protectorate. ${ }^{61}$ In January 1890 Menelik II wrote directly to the German government, expressing the desire to continue friendly relations, solidarity among "all unfairly oppressed people” and asking for help in having the weapons embargo lifted. As Menelik had not used the good offices of Italy as stipulated at Wuchale, the Italian press was up in arms. Germany did not want to upset its Italian ally and drafted in collaboration with Italian diplomats a friendly but noncommittal response. The Italian diplomatic service relayed the letter of Wilhelm II to the Ethiopians. ${ }^{62}$ After finding a similar reception in other European states, Ethiopia unilaterally revoked the Treaty of Wuchale in 1893 which led to war between Italy and Ethiopia in 1896 and the crushing defeat of the Italian forces at Adua near the Eritrean border. The Ethiopian victory over the Italians, including the capture of thousands of Italian soldiers, was suffered in Italy as an insult to national pride and reverberated around the world, demonstrating to many in Africa, Asia and America that European conquest domination was not inevitable. ${ }^{63}$

Although the mountainous and landlocked Ethiopia lacked an effective road or railway system the country had seen the influx of merchants, missionaries, and explorers from Europe, Arabia, Turkey, Armenia and India in the nineteenth century, tying the country into the global market of wares and ideas. ${ }^{64}$ Already before becoming Negus Negesti, the king of kings, Menelik had been an avid moderniser and technology aficionado in his province of Shoa. Like his second in command, the general Ras Makonnen, Menelik had cultivated relations with the European powers before 1889, skilfully playing off the Europeans against Yohannes, amassing European weapons and expanding his basis of power and territorial control. After victory at Adua, Menelik exclaimed "What kind of fools are there in Europe? Why! Do they make their weapons of death and give them to us? With guns which they have brought, with cartridges that they have brought Menelik has roasted and exploded the foreign barley." 65 Marrying Taitu Betul, who commanded a power basis in the northern region around Gondar, Taitu and Me-

61 Christopher Clapham, "Mənilək II," in Encyclopaedia Aethiopica. A Reference Work on the Horn of Africa, vol. 3, Siegbert Uhlig (Wiesbaden: Harrassowitz, 2007), 924.

62 Tafla, Ethiopia and Germany, 91-92.

63 Raymond Jonas, The Battle of Adwa. African Victory in the Age of Empire (Cambridge, MS: Belknap Press, 2011).

64 Pankhurst, "Foundation of Addis Ababa," 109.

65 Clapham, "Mənilək II,” 923; Marcus, Menelik II and Ethiopia, 174; Avishai Ben-Dror, "Arthur Rimbaud in Harär: Images, Reality, Memory,” Northeast African Studies 14, no. 2 (2014): 159-82. 
nelik became a formidable ruling couple. Menelik and Taitu sought to establish a modern empire and imported European technology and those who mastered its application. Particularly important became a Swiss engineer by the name of Alfred Ilg, who had joined Menelik in Shoa in 1879. Ilg became Menelik's trusted advisor on matters of public construction and trade, and acted by the 1890 s as his de facto secretary of state. ${ }^{66}$ After the revocation of Wuchale in 1896, Ilg organised a publicity campaign in Europe to raise the profile of his chief, and Ethiopia entered diplomatic relations with France, Russia, and England in the late 1890s. Humiliated Italy also opened a legation in the by Menelik and Taitu newly established capital Addis Ababa. ${ }^{67}$

Menelik was interested in "attracting as many foreign powers as possible for reasons of political expediency”, as Tafla notes, but Germany maintained its distance from Ethiopia and continued to rely on Italy for correspondence. In 1901, Menelik wrote to Wilhelm to offer trade relations and to have his sovereignty recognised by another European power. The Kaiser was interested and Italy signalled no objections, but Bülow thought it prudent to wait. Ethiopia's profile was rising. A number of German and Austrian scholarly expeditions to the Horn of Africa had popularised the region and businessmen, like the sugar industrialist and ethnologist Max Schoeller of German East Africa, were interested in Ethiopia's resources - particularly its coffee beans. ${ }^{68}$ Most persistent in lobbying was Arnold Holtz, a German adventurer with ties to the colonialist Alldeutsche circles. Holtz began approaching the Auswärtiges Amt in 1901 for support with his business ventures in Ethiopia. But due to the bad accessibility, doubts as to the real economic benefits and continued fears of upsetting Italy, Holtz was kept on standby. ${ }^{69}$ The German government only threw its reservations overboard after a US delegation travelled to Ethiopia to enter a trade deal in 1903 and the

66 Clapham, "Mənilək II," 923; Jonas, Battle of Adwa, 13.

67 Marcus, Menelik II and Ethiopia, 179; Pankhurst, "Foundation of Addis Ababa”; Robert Chauvelot, Un grand politique, S. M. l'empereur Ménélik II, roi des rois d'Éthiopie. Conférence prononcée à l'École des Sciences Politiques (Section Diplomatique) (Paris: Francis Laur, 1899), 15-19; Jonas, Battle of Adwa, 271; “Convention with the Negus," Egyptian Gazette, 30 July 1903; Tafla, Ethiopia and Germany, 92.

68 Tafla, Ethiopia and Germany, 99-102; Richard Goodmann, “Arthur Rimbaud, Coffee Trader,” Saudi Aramco World 52, no. 5 (September 2001): 8-15.

69 Friedrich Rosen, Aufzeichnung über Arnold Holtz, 12 July 1905, A 12285, R 14915, PA AA; Arnold Holtz to Arthur von Zimmermann, 1 September 1903, A 10947, R 14891, PA AA; Arnold Holtz to AA, 30 October 1903, A 16121, R 14891, PA AA; Arnold Holtz to AA, 3 November 1903, A 16403, R 14891, PA AA; Inhouse Report, 5 August 1903, R 14891, PA AA; Hermann Speck von Sternburg to Bernhard von Bülow, 17 October 1903, A 222, R 14891, PA AA; Zimen, Rosen für den Negus, 10-21. 
newspapers reported at length on the economic potential of Ethiopia and US "participation in 'Weltpolitik", ${ }^{70}$

With Ethiopia considered part of the Orient, Holtz's inquiries fell on Rosen's desk. The other parcel of the Ethiopia portfolio were a number of reports from Jerusalem, Constantinople and Cairo about Ethiopia trying to (re)claim the Deir es-Sultan monastery adjacent to the Holy Sepulchre in Jerusalem from the Coptic Church. This was complicated by the Coptic Patriarch of Alexandria appointing the Abuna (primate) of the Ethiopian Church and the leader of the Church thus often not pursuing the same goals as the Ethiopian government. Negotiations had come to naught and Empress Taitu's visit to Jerusalem in 1904 also did not result in the hoped-for success. ${ }^{71}$ From 1903 on, Rosen read most of the economic, religious and political reports and inquiries concerning Ethiopia, but had not become active on the country in any major capacity. Just as an Ottoman mission to Addis Ababa passed the Suez Canal in May 1904, the Auswärtiges Amt started moving and under secretaries of state Oswald von Richthofen and Otto von Mühlberg sought to get a German mission to Ethiopia underway. ${ }^{72}$

Richthofen, Mühlberg and Rosen likely came up with the idea together. ${ }^{73}$ Rosen privately discussed establishing diplomatic relations with Mühlberg, who had been on the Orient desk before Rosen. Mühlberg told Rosen that an expedition to Ethiopia "would make a good impression with the public." In May 1904 Rosen spoke with the explorer and ornithologist Carlo von Erlanger about a potential mission. Erlanger had travelled Ethiopia between 1899 and 1901, where he captured 8,000 birds, spent several months at the court of Menelik, and made the acquaintance of Ilg. The young bird-collector suggested to Rosen that a diplomatic mission to Ethiopia would prove a success. The recently signed Franco-British Entente had the French decrease their influence in the re-

70 "American Aspirations. Mission to Abyssinia," The Morning, 22 September 1903; "Encore un rival,” Gil Blas, 18 September 1903; “Trade Possibilities in Abyssinia,” Egyptian Gazette, 9 June 1904; Marcus, Menelik II and Ethiopia, 198; Martin Rücker Freiherr von Jenisch to Bernhard von Bülow, 27 June 1904, A 11126, R 14891, PA AA; Martin Rücker Freiherr von Jenisch to Bernhard von Bülow, 28 December 1904, A 8995, R 14892, PA AA.

71 Edmund Schmidt to Bernhard von Bülow, 24 May 1904, A9525, R 14891, PA AA; Martin Rücker Freiherr von Jenisch to Bernhard von Bülow, 31 May 1904, A 8994, R 14891, PA AA; Bernhard von Bülow to Wilhelm II, 28 August 1904, A 13772, R 14891, PA AA; “Eine Pilgerfahrt der Kaiserin von Abessynien nach Jerusalem,” Frankfurter Zeitung, 1 June 1904.

72 Martin Rücker Freiherr von Jenisch to Bernhard von Bülow, 21 May 1904, A 260, R 14891, PA AA; Martin Rücker Freiherr von Jenisch to Bernhard von Bülow, 28 December 1904, A 8995 , R 14892, PA AA.

73 Tafla notes that the driving force was Richthofen alone. Tafla, Ethiopia and Germany, 98. 
gion, which could provide an opening for Germany, and allow it to draw closer to both Russian and Italian interests in the country. ${ }^{74}$ The idea was endorsed by Wilhelm in late August. Bülow first brought up the matter with Wilhelm on 26 August and sent him a detailed report on Ethiopian Church interests in Jerusalem on 28 August, suggesting that Bülow tried to pique the Kaiser's interest on the matter on a religious basis. ${ }^{75}$

German motivations were interlaced. After a series of states had entered diplomatic relations with Ethiopia, the German government no longer wanted to look like it was holding back. Secondly, signing a trade treaty and "opening up" Ethiopia to German economic interests allowed the government to point to its track record of supporting German exports in the public. In combination, these economic and political goals would also placate colonialist circles, who insisted on Bülow's making good on his place in the sun claim from 1897. The concrete goals of the mission were to negotiate a trade and friendship treaty and to further investigate economic opportunities, as business circles in the US continued to doubt trade prospects and Holtz's marketing was not trusted. Nothing indicates that at the outset the Auswärtiges Amt intended to make a show-case of diplomacy or international collaboration with France, Britain and Italy out of the expedition. But the German government demonstrated goodwill in informing the other interested European governments in London, Paris, Rome and Cairo of the expedition two months before its departure and sought permission from all to pass their territories into and out of Ethiopia. The line presented to the British,

74 Erlanger suggested to Rosen that he would send a map of Ethiopia he had published with the Gesellschaft für Erdkunde (association for geography) in Berlin to Ilg and Menelik as a gift. It should be accompanied by a letter co-written with Rosen. Erlanger died in a car accident in the fall of 1904. Carlo von Erlanger to Friedrich Rosen, 13 June 1904, 1901-5, ASWPC; Friedrich Rosen, 1926, Hinterlassene Manuskripte I, 6 NL Müller-Werth, PA AA, 89; Carlo von Erlanger, “Am Hofe Kaiser Meneliks,” Die Woche 3, no. 2 (1901): 1961-64; Carlo von Erlanger, "Bericht über meine Expedition in Nordost-Afrika in den Jahren 1899-1901," Zeitschrift der Gesellschaft für Erdkunde zu Berlin, no. 2 (1904): 89-117; "Verhandlungen der Gesellschaft. Allgemeine Sitzung vom 15. Oktober 1904," Zeitschrift der Gesellschaft für Erdkunde zu Berlin, no. 5 (1904): 553-57; Paul Sprigade, "Geographische Ergebnisse der Expedition von Carlo Frhr. v. Erlanger in Nordost-Afrika in den Jahren 1899-1901,” Zeitschrift der Gesellschaft für Erdkunde zu Berlin, no. 2 (1904): $118-31$.

75 Tafla, Ethiopia and Germany, 98; Martin Rücker Freiherr von Jenisch to Bernhard von Bülow, 21 May 1904, A 260, R 14891, PA AA; Bernhard von Bülow to Wilhelm II, 27 November 1904, A 18642, R 14914, PA AA; Bernhard von Bülow to Wilhelm II, 28 August 1904, A 13772, R 14891, PA AA. 
French and Italians was that Germany was in it for economic reasons and pursued no political interests. ${ }^{76}$

As the planning of the expedition took on shape, the scope of German interests widened. Tasked with inquiring at the Ethiopian court, if a German delegation was to be received favourably, Holtz also pursued his own business interests. As representative of Krupp in Ethiopia, he arranged for the armament manufacturer to extend their catalogue to Menelik via the German delegation. As the emperor had expressed an interest in Krupp mountain guns before, a sample artillery piece could be sent to Ethiopia. ${ }^{77}$

With the Kaiser's interest sparked in the religious relevance of Ethiopia, the expedition was infused with a more inquisitive dash. Menelik II claimed descent from Menelik I, the legendary son of Makeda aka Queen of Sheba and King Solomon. In the tenth century before Christ, Menelik I was supposed to have transported the Ark of the Covenant with divine help to Ethiopia, where it was since kept in its ancient capital Aksum. The hunt for the Ark of the Covenant was a common past-time of European adventurers, but Wilhelm's focus was directed by his intimus, the Protestant theologian Adolf von Harnack, towards finding manuscripts in Ethiopia that would shed light on the development of early Christianity. ${ }^{78}$ Ethiopia, which had a long Jewish history, had become predominantly Christian in the fourth century. Harnack hypothesised that Ethiopian manuscripts would hold indications of early Christianity not recorded in Greek sources. For the purpose of finding out more, Harnack and Rosen arranged for the Bonn university librarian and student of Ge'ez (old Ethiopian) manuscripts, Johannes Flemming, to accompany the mission. With Germany's library collections lagging behind those in Paris and London, Flemming should get a purse of 10,000 Mark to buy old Ethiopian manuscripts. ${ }^{79}$ A linked goal, Harnack suggest-

76 Otto von Mühlberg to von Jenisch, 22 November 1904, A 18306, R 14914, PA AA; Hugo von Radolin to AA, 17 November 1904, A 18070, R 14914, PA AA; Auswärtiges Amt to Hugo von Radolin, 17 November 1904, A 18070, R 14914, PA AA.

77 Friedrich Rosen to Bernhard von Bülow, 2 March 1905, A5011, R 14892, PA AA; Otto Eccius to Friedrich Rosen, 20 December 1904, A 20016, R 14914, PA AA; von Erlanger, "Expedition in Nordost-Afrika 1899-1901,” 104.

78 Enno Littmann, The Legend of the Queen of Sheba in the Tradition of Axum (Leiden: E.J. Brill \& Princeton University Library, 1904); Röhl, Der Aufbau der persönlichen Monarchie, 1052-53; Matthias Steinbach, "Wilhelm II. und die Gelehrten: Aspekte einer Beziehungsgeschichte," in Wilhelm II. Archäologie und Politik um 1900, Thorsten Beigel and Sabine Mangold-Will (Stuttgart: Franz Steiner, 2017), 30.

79 Johannes Flemming to Adolf Harnack; Adolf Harnack to Friedrich Rosen, 8 December 1904, 1901-5, ASWPC; Konrad von Studt and Otto von Mühlberg to Wilhelm II, 20 December 1904, 
ed, was to impress the royal Ethiopian couple with German studies of Ethiopian history and religion going back to the collaboration of the Ethiopian priest Abba Gorgoryos and the German Orientalist Hiob Ludolf on a Latin-Ge'ez dictionary at Gotha in the seventeenth century. More recent scholarship by the Bible scholar August Dillmann with his linguistic studies of Ethiopian languages, and Johannes Flemming's very own translation of the Book of Enoch from Ge'ez to German, were also expected to impress. ${ }^{80}$ Copies of these books, as an example of masterly German book-print, were to be gifted to Menelik and Taitu to glorify Germany's prestige and induce the court to offer support to Flemming's manuscript acquisition mission. The German minister of culture, Konrad von Studt, supported the endeavour and hoped the Kaiser might chip in with the expenses. ${ }^{81}$

As Rosen became slated to lead the expedition in November 1904, the scientific scope of the delegation expanded with the inclusion in the delegation of Rosen's brother Felix, whose botanical career in Breslau (Wcrocław) had come to a standstill. ${ }^{82}$ Next to his interests in finding as yet uncategorised plants, Felix also secured funding from the Rudolf Virchow foundation in Berlin and the royal house of Württemberg in Stuttgart, so that he could take phonographic and photographic apparatuses with him to Ethiopia and record the mission in sound and image. Berlin's Völkerkundemuseum asked Felix to purchase ethnographic items for its collection. ${ }^{83}$ The delegation was completed by the medical doctor Hans Vollbrecht, the three trade-diplomatic staffers Becker, Carl Bosch and Edmund Schüler, and Viktor zu Eulenburg, a military officer attached to the German embassy in London and son of August zu Eulenburg at the court of Wilhelm II. The last appointment in particular had rattled Rosen. Eulenburg had participated in the crackdown of the Boxer Uprising in China in 1900-1,

A 19757, R 14914, PA AA; Friedrich Rosen, 1926, Hinterlassene Manuskripte I, 6 NL Müller-Werth, PA AA, 90.

80 Johannes Flemming to Adolf Harnack; Adolf Harnack to Friedrich Rosen, 8 December 1904, 1901-5, ASWPC; Anaïs Wion, "Collecting Manuscripts and Scrolls in Ethiopia: The Missions of Johannes Flemming (1905) and Enno Littmann,” in In kaiserlichem Auftrag: Die Deutsche AksumExpedition 1906 unter Enno Littmann. Band 2. Altertumskundliche Untersuchungen in Tigray/ Äthiopien, Steffen Wenig (Wiesbaden: Reichert, 2012), 353-54.

81 Konrad von Studt and Otto von Mühlberg to Wilhelm II, 20 December 1904, A 19757, R 14914, PA AA.

82 Felix Rosen, Die Natur in der Kunst. Studien eines Naturforschers zur Geschichte der Malerei (Leipzig: B.G. Teubner, 1903); Felix Rosen, Curriculum Vitae, 29 October 1892, F 28, AUW; Felix Rosen, Gesuch zur Beurlaubung für den Rest des laufenden WS, December 1904, F 84, AUW; Felix Rosen, "Bruder Dornbusch,” 406.

83 Konrad von Studt to Felix von Luschan, 12 December 1904, RO Afr. R., PA EMB; Felix Rosen to Felix von Luschan, 18 December 1905, RO Afr. R., PA EMB. 
and Rosen feared that the officer would not to conform with a diplomatic mission in an extra-European environment. Attached to the mixed group of men were eight elite soldiers from the Kaiser's bodyguard, the Gardes du Corps, who were tasked with adorning the delegation and practicalities like tent construction and security. ${ }^{84}$

The express justification for Rosen's appointment to head the Sondergesandtschaft (special mission) was that he was an Orient expert and by $1904 \mathrm{a}$ diplomat trusted by the Kaiser. Rosen would in retrospect come to think that Holstein had gotten him removed from Berlin in the build-up of making a stand at Tangier in the spring of 1905 - a move which Rosen opposed. ${ }^{85}$ Rosen's knowledge of people or things Ethiopian were scant. Although the head of the AngloProtestant Bishopric in Jerusalem during Rosen's father's time as consul there, Samuel Gobat, had led a mission to Ethiopia before settling in the Holy City, Rosen does not mention any exposure to Ethiopia or Ethiopians in his childhood. Only when Rosen returned to Jerusalem as consul in 1899 did this change, when he met a young German scholar of Semitic languages, who had come to Jerusalem to study Arabic, Amharic and Ge'ez with the Ethiopian Abba Kefla Giorgis. Over dinner at the German consulate Enno Littmann talked with Rosen about his research interests in ancient and modern Ethiopian culture and language. Moreover, Rosen followed the Deir es-Sultan conflict and the Ethiopian construction of the Debre Genet monastery outside of the city walls, and the Ethiopian colony located in short walking distance from the new German consulate building outside the city walls. ${ }^{86}$ However, only when he moved to the

84 Karl von Einem to Friedrich Rosen, 11 December 1904, A 1489, R 14914, PA AA.

85 It is unclear if there was a causal connection of the Morocco affair to Rosen's appointment as head of the mission. Müller-Werth found no proof in the archives of the Auswärtiges Amt substantiating Rosen's suspicions. Holstein uttered unease to Bülow in September 1904 about no longer having a higher standing at the Auswärtiges Amt than Rosen. Bülow noted in his memoirs that the "quarrelsome" Holstein had taken "Rosen, god knows why, en grippe" in the summer of 1905. Müller-Werth, Ein staatsmännisch denkender Diplomat, 59; Norman Rich, M.H. Fisher, and Werner Frauendienst, eds., Die Geheimen Papiere Friedrich von Holsteins. Briefwechsel 10. Januar 1897 bis 8. Mai 1909 (Göttingen: Musterschmidt, 1963), 275, 331; Bernhard von Bülow, Denkwürdigkeiten. Von der Marokko-Krise bis zum Abschied, Franz von Stockhammern (Berlin: Ullstein, 1930), 168; Frederic Whyte, trans., Letters of Prince von Bülow. A Selection from Prince von Bülow's Official Correspondence as Imperial Chancellor During the Years 1903-1909, Including, in Particular, Many Confidential Letters Exchanged Between Him and the Emperor (London: Hutchinson \& Co, 1930), 125.

86 Barbara Strebel, “Gobat, Samuel," in Encyclopaedia Aethiopica. A Reference Work on the Horn of Africa, vol. 2, Siegbert Uhlig (Wiesbaden: Harrassowitz, 2005), 818-19; Friedrich Rosen to Enno Littmann, 3 January 1900, 1, 28 NL 245 EL, StaBiB; Enno Littmann, Study Book in Arabic from Jerusalem, February 1900, 71 NL 245 EL, StaBiB; Guébré Sellassié and Maur- 
Orient desk did Rosen come to deal with Ethiopia professionally, and even then Ethiopia remained on the margins of his ambit. Littmann, then at Princeton, wrote to Rosen in early 1902 to update him on his latest publications on Amharic and that he had learned in a conversation with the journalist and French envoy to Ethiopia Hugues le Roux that the country was by now "almost the only really independent state in Africa, gaining more and more in significance", and that there was a struggle for influence between the European powers at Menelik's court, as the country promised rich gold resources and was in a position to cut off the Nile water supply to Egypt. ${ }^{87}$ Apart from these geo-strategic considerations and limited Jerusalem familiarisation, Rosen had little prior exposure to Ethiopia.

Language was the first problem for the German delegation. No one knew Amharic. The ancient Ge'ez read by Flemming was not going to be of much assistance as the librarian self-critically pointed out, so one of Rosen's first tasks as head of the mission was to recruit an interpreter. As Amharic was not taught at the SOS and virtually unknown in Germany at the time, the general consulate in Cairo arranged for someone to join the mission en route to Ethiopia who was able to write formally in negotiations with Menelik, and did not cost too much. This was to be Wolde Mariam, a native speaker of Amharic, who was fluent in Arabic and could thus interpret for Rosen and Bosch, who also knew a bit of Arabic. ${ }^{88}$ If Rosen was in any way the most knowledgeable German diplomat of rank at disposal, it was only partially his previous exposure to the country that qualified him. The view from the Auswärtiges Amt was Orient is Orient, and also Rosen thought about Ethiopia in terms of place, culture and people outside of Europe. Yet, as his first move - finding a reliable interpreter - demonstrates, he was acutely aware of his and his mission's lack of knowledge about Ethiopia. His brother Felix and Flemming began studying previous travel accounts in European languages and maps by geographical expeditions, but as would become clear in Ethiopia much of the information provided was entirely

ice de Coppet, eds., Chronique du règne de Ménélik II. Roi des rois d’Éthiopie, trans. Tèsfa Selassié (Paris: Librairie orientale et américaine, 1932), 514-17; Enno Littmann, "Nachruf. Friedrich Rosen,” ZDMG 89 (1935): 394; Verhandlungen des XIII. internationalen Orientalisten-Kongresses. Hamburg September 1902 (Leiden: E.J.Brill, 1904), 271-72.

87 Enno Littmann to Friedrich Rosen, 23 March 1902, 1901-5, ASWPC.

88 Johannes Flemming to Adolf Harnack; Adolf Harnack to Friedrich Rosen, 8 December 1904, 1901-5, ASWPC; Martin Rücker Freiherr von Jenisch to Friedrich Rosen, 2 December 1904, A 1913, R 14914, PA AA; Friedrich Rosen to Martin von Jenisch, 22 November 1904, A 18899, R 14914, PA AA; Martin Rücker Freiherr von Jenisch to Friedrich Rosen, 2 December 1904, A 22991, R 14914, PA AA; Hans Vollbrecht, Im Reiche des Negus Negesti Menelik II. Eine Gesandtschaftsreise nach Abessinien (Stuttgart: Union Deutsche Verlgagsgesellschaft, 1906), 25. 
fanciful or inaccurate. ${ }^{89}$ The German diplomatic mission became a study excursion to remedy a lack of knowledge in all fields. As Felix Rosen explained to the director of the Berliner Völkerkundemuseum after the expedition, he had "no adventures" to boast about, but could report on Ethiopian "flora, fauna, geography and ethnography". ${ }^{90}$

The Ethiopian government's repeated expressions of interest in establishing relations with Germany were motivated by a number of considerations. Barely half the size before Menelik's accession to power, by 1904 Ethiopian territory expanded onto the borders of French Djibouti, British Sudan, Somaliland and East Africa, and Italian Somalia and Eritrea. Menelik, Taitu, Ilg and Ras Makonen reasoned that bringing in further European powers would balance out the influence of the European neighbours. Although Ethiopia had delineated its borders with Britain (1897 and 1902) and Italy (1896), was at peace and growing in economic productivity, the state was still young and for most of its technological advances dependant on European or Asian expertise or imports. With a reputation for military might, a growing economy, scientific advances and without noticeable territorial ambitions, Germany, it was hoped, would help with economic development and serve as an additional guarantor of Ethiopian independence. Russia, which Ethiopia had tried to interest in its affairs in the past, had been unrewarding, and although Ethiopia moved closer to the Ottoman Empire over its church affairs, diplomatic recognition by "the sick man of Europe" was not nearly as valuable in terms of sovereignty as that of Germany. Whether Menelik and his advisor Ilg had considered including Germany in any other concrete plans or projects before the arrival of the mission in February 1905 is unclear. The conflict between Ilg and the de facto German representative before the arrival of the official mission, Holtz, that the European press reported on shortly before the departure of the Rosen mission indicates that neither Ilg nor Menelik had hoped to gain more than symbolic recognition and German involvement. ${ }^{91}$

89 Felix Rosen to Nina Rosen, 26 March 1905, Briefe aus Abessinien, ASWPC; Felix Rosen, Eine deutsche Gesandtschaft in Abessinien (Leipzig: Veit \& Co, 1907), 23, 49, 133-34; Konrad von Studt and Otto von Mühlberg to Wilhelm II, 20 December 1904, A 19757, R 14914, PA AA.

90 Felix Rosen to Felix von Luschan, 8 January 1906, RO Afr. R., PA EMB.

91 Holtz plotted against Ilg at the Ethiopian court, accusing him of selling out the country to France and being a Germanophobe. According to the story Holtz fed to a number of international papers, Ilg had then been removed from power by Menelik. In November 1904 the Neue Zürcher Zeitung clarified that Holtz had been the source of "false rumours", while Ilg had been on leave in Switzerland. Holtz's stay in Berlin over the summer of 1904 was due to his expulsion from Ethiopia upon Ilg's return. Otto Eccius to Friedrich Rosen, 20 December 1904, A 20016, R 14914, PA AA; "Ratgeber des Kaisers Menelik," Neue Preußische Zeitung 527 (9 November 1904); Friedrich Rosen, Aufzeichnung über Arnold Holtz, 12 July 1905, A 12285, R 14915, 
Notwithstanding first signs of his questionable reliability, Holtz remained in charge of announcing the German mission to Menelik and arranging transportation of people, equipment and presents from the Ethiopian border to Addis Ababa via caravan. On 6 January 1904 the mission landed in Djibouti, where it was received "obligingly" by the French authorities and travelled to the town of Dire Daua in Ethiopia on the French constructed railway. The railway construction had come to a stand-still after the Fashoda Incident in 1898 led to a rapprochement between France and Britain, and France gave up on linking its possessions in Africa by rail from East to West. Having run out of money after the loss of political backing, the French governor and the railway directorate in Djibouti were keen on interesting the Germans in the project, and Rosen noted in his report back to Berlin that this appeared to be directed from Paris. ${ }^{92}$ At Dire Daua, it turned out that the caravan with which the mission and its gifts were to be transported to Addis Ababa was inadequately prepared by Holtz. The mechanic he sent from the capital was also unable to dissemble and pack up the Daimler truck that the mission had brought along on behest of Holtz. The mules and donkeys that awaited the mission were not well-fed and their pack saddles were ill-suited to carry the wares of the mission. Friedrich and Felix squarely blamed Holtz for the shortcomings. ${ }^{93}$ In Djibouti, Rosen had hired some one hundred and ninety Somalis of the Habr Aual tribe to lead the animals, but now more mules had to be bought, delaying the departure by several days and resulting in splitting the travelling party into three. ${ }^{94}$

Onward travel was slow, with Rosen complaining in a letter to Nina that unlike the caravans he was used to in Iran and the Fertile Crescent, the animals could only walk some four hours at a stretch before having to rest for several hours. Nevertheless, many a mule was left along the wayside. After Eulenburg had shot dead the first mule that had broken down, the Somali guides demurred, as this was against their caravaners' code and brought bad luck. The Germans were informed that the animals might recover and it was not up to their keepers

PA AA; Arnold Holtz to Friedrich Rosen, 11 December 1904, A 19232, R 14914, PA AA; Arnold Holtz to Friedrich Rosen, 11 December 1904, A 19232, R 14914, PA AA; Otto Eccius to Friedrich Rosen, 20 December 1904, A 20016, R 14914, PA AA.

92 Friedrich Rosen to Nina Rosen, January 1905, Briefe aus Abessinien, ASWPC; Friedrich Rosen to AA, 6 January 1905, A 284, R 14914, PA AA; Friedrich Rosen to AA, 20 February 1905, A 4376, R 14914, PA AA; Felix Rosen, Gesandtschaft in Abessinien, 5; Carl Bosch, Karawanen-Reisen. Erlebnisse eines deutschen Kaufmanns in Ägypten, Mesopotamien, Persien und Abessinien (Berlin: August Scherl, 1928), 143; Friedrich Rosen, Auswärtiges Amt. Marokkokrise, 128.

93 Friedrich Rosen to Nina Rosen, 22 January 1905, Briefe aus Abessinien, ASWPC; Felix Rosen, Gesandtschaft in Abessinien, 23.

94 Felix Rosen, Gesandtschaft in Abessinien, 9, 101; Bosch, Karawanen-Reisen, 151. 
to decide their fate. Although he thought that most would fall prey to hyenas, Felix recognised that in fact some might get up again and then be claimed by locals. Considering that Rosen was by and large the only person in the mission who could communicate with the Somali packers and with locals in mostly Somali-inhabited Eastern Ethiopia in Arabic, there were bound to be further issues of understanding. When after an evening of carousing, a mutiny broke out among the packers against the hasty speed of the caravan and inadequate pay, the situation became dicey, and Felix was afraid of being lynched. Friedrich had the ringleaders seized and shackled by the escorts that had remained loyal to the Germans under the lead of the interpreter Wolde Mariam. To prevent the situation from escalating further, Rosen did not involve the Gardes du Corps. He redistributed the right to carry rifles, rewarding those who had stayed away from the strike, thus subduing the protesters. ${ }^{95}$ There were other conflicts along the way, and Felix thought that the composition of the caravan of "Christians, Muslims and heathens, Europeans, Egyptians, Abyssinians, Somali, and Galla” was enough "fuel for conflict", but praised his brother for not tolerating violence:

In diesem wichtigen Punkte kamen meinem Bruder die Erfahrungen langjährigen Aufenthaltes in orientalischen Ländern zugute. Im Gegensatz zu manchem Afrikareisenden hatte er jede körperliche Züchtigung ein für allemal untersagt... die Disziplin [wurde] durch eine allmählich von uns eingeführte gründliche Marsch- und Lagerorganisation aufrecht erhalten und durch das gute Beispiel, welches den Einheimischen die Arbeitsamkeit und Manneszucht unsrer deutschen Soldaten gab... die Behandlung, welche wir den Eingebornen angedeihen ließen, war richtig und der Nachahmung wert, denn sie ermöglichte uns im fremden Land, wo wir oft gezwungen waren das Gastrecht in Anspruch zu nehmen, auf einem so langen und mühseligen Marsch auch die geringsten der Landesbewohner immer als Freunde zu behandeln ${ }^{96}$

Written a year after the journey, description should be read as commentary of German colonialism and the massacres committed by Germans in East Africa during the Maji Maji Uprising (1905-1907) and in South West Africa against the Herero and Namaqua (1904-1907). It was also a depiction of the self-under-

95 Felix Rosen, Gesandtschaft in Abessinien, 76-91.

96 "In this important point my brother benefitted from his long years of residence in Oriental countries. In contrast to many a Africa traveller he had interdicted bodily castigation once for all... Discipline was maintained by a gradually introduced, thorough marching and camping organisation, and by the good example that the industriousness and the discipline of our German soldiers set for the indigenous... the treatment, which we afforded the natives, was right and worthy of imitation, because it enabled us in a foreign land, where we were often forced to avail ourselves of the right to hospitality, on such a long and arduous march to treat also the lowest of the country's inhabitants as friends.” Felix Rosen, Gesandtschaft in Abessinien, 164. 
standing of the mission. The Germans perceived themselves to be superior and should lead by example. Friendship or friendly relations were possible and desirable. Although there was no level playing field, the Germans became quite reliant on their Ethiopian and Somali escorts. Not only was Wolde Mariam - "quite a gentleman" Friedrich thought - of crucial significance for the mission to communicate with locals along the way, but in a number of letters to Nina, Friedrich painted a clear picture of how lost the German members of his mission were without their Somali and Ethiopian escorts: ${ }^{97}$

I am very much disturbed, especially as I know Arabic. Flemming knows neither Arabic nor modern Abyssinian enough to make use of. Bosch speaks Kitchen-Arabic and makes himself useful haranguing the cooks, but most of the translating fall to my lot, in fact I am “dragoman et ambassadeur"... We have each of us a Somali boy as special servant and an Abyssinian for each riding mule... They are all Moslims and there is no love lost between them and the Abyssinians. It is however better not to depend entirely on the latter, as they are lazy and unruly. The Somalis on the other hand are excellent and all speak Arabic and French. Their French is very comic: "M'seiur Moanstere voila. Moi aller au lager bour manger, voila. Moi acheter barabluie bour toi et bour Felix, voila. Donne moi argent voila.” This is a specimen of their French. Still it is better than the French of some of our gentlemen. Oberstabsarzt Vollbrecht does not know French any more, but quietly speaks "Plattdeutsch" to them. They are quick enough to understand it. Becker on the other hand tries to improve his French by speaking to his Somali! He has studied modern languages at the University! I always speak Arabic to them, which they know much better, of course, though by no means perfectly. They are a cheerful and sympathetic lot and quite poetic in their ideas. ${ }^{98}$

Rosen's first recorded meeting of Somalis had been when visiting the African ethnological exhibition at the Crystal Palace in 1895 with Nina's sister Marie:

Fritz went up and said a few words to these poor exiled fellows and the delight depicted on their faces at hearing their own language spoken was quite wonderfully touching. They crowded round Fritz and at one moment I thought they would have embraced him. His few words had evidently brought back their far-away sunny country to them, and given them a few moments of joy in the midst of their (to them) strange surroundings. ${ }^{99}$

97 Friedrich Rosen to Nina Rosen, January 1905, Briefe aus Abessinien, ASWPC; Friedrich Rosen to Nina Rosen, 20 February 1905, Briefe aus Abessinien, ASWPC.

98 "Mister minister, voila. I go to the camp to eat, voila. I buy umbrella for you and for Felix, voila. Give me money, voila." Plattdeutsch is lower German. Friedrich Rosen to Nina Rosen, 22 January 1905, Briefe aus Abessinien, ASWPC.

99 Dickens, Mumsey's Recollections, 50; Carl Hagenbeck, East African Village and Great Display by Natives of Somaliland (Sydenham: Crystal Palace Company, 1895). 
As spine-crawling as that first encounter was, Rosen took a liking to the Somalis facilitating his diplomatic mission in 1905. His servant Mahmud Abdi taught him some of his poems and Rosen took every chance to hear, write down and record songs in Somali, Amharic and Tigre. The better part of his free time he passed compiling samples of song and music. As Teffera noted, most of the forty-six songs recorded on wax-cylinder along the way of the mission were of low quality, selected randomly, without geographical or temporal specification. ${ }^{100}$ But the musical practice appears to have led to a fair bit of social bonding beyond cultural lines. When the Somali warrior Sheual Abdi, a widely respected and feared chief of the Habr Aual tribe in the service of Ras Makonnen, visited the mission's camp, he was asked to sing one of his songs into the phonograph. Saying he would only do so if a German went first, Bosch sang into the machine Strömt Herbei Ihr Völkerscharen (come forth ye multitudes), a song exalting the Rhine River and its wine. Satisfied with Bosch having "roared like a lion", Sheual gave a number of renditions of songs glorifying his deeds in battle, closing with an improvisation that saluted Rosen as envoy of the courageous German tribe and its all-seeing Kaiser. ${ }^{101}$

The encounters and meetings with the governor of Harar, Ras Makonnen Wolde Mikael, and his son Tafari Makonnen Wolde Mikael (the later Haile Selassie) provided further opportunities for the acculturation of the German mission. Ras Makonnen was known as being particularly open to European cultural influences. A friend of the French poet Arthur Rimbaud, he had attended the coronation of King Edward VII in London in 1902 and was Menelik's right-hand man and prized general at Adua. The German mission found that despite his education, elegance and distinction of character, the ceremonials of state encounter were conducted according to Ethiopian ways. The welcoming parades were not organised according to German expectations of neat categorical and geometrical separations, but met head on and then intertwined to create a common, mixed

100 Timkehet Teffera, "Historische Tonaufnahmen aus Abessinien: Walzensammlung Rosen 1905,” Essay, 2005, RO Afr. R., PA EMB; Friedrich Rosen to Nina Rosen, 22 January 1905, Briefe aus Abessinien, ASWPC.

101 Sheual Abdi had fought alongside the Somali Sufi leader Mohammed Abdullah Hassan (the Mad Mullah to many Europeans) against the Italians, British and Ethiopians, before joining the side of Ras Makonen. The other songs Abdi sang for Rosen and the surrounding Somalis were recounting the story of how he turned away from Hassan. Unfortunately, Bosch roaring like a lion was razed of the wax cylinder before the hand over to the Völkerkundemuseum. Vollbrecht, Im Reiche des Negus, 108; Felix Rosen, Gesandtschaft in Abessinien, 109-20; Felix Rosen, Verzeichnis der in Abessinien (Frühjahr 1905) aufgenommenen Phonogramme, Spring 1905, 108155, RO Afr. R., PA EMB; Bosch, Karawanen-Reisen, 147. 
procession. ${ }^{102}$ Rosen was awarded with expensive gifts, an elegant mule, an honour shield with lances, and a monkey tale as a fly-whisk against the dust and insects. Conversation was polite, and after hours of pleasantries that were utterly boring to the larger part of the German mission, Rosen asked Ras Makonnen for additional pack animals, a wish that was promptly granted with a number of camels to relieve the mules from the heavier freight. Still at near quarters for Kaiser's birthday a joint celebration was held, with a riding competition, goats slaughtered according to Muslim and Christian rites, followed by what appears to have been quite a feast. When the mission continued Rosen had the shield and lances carried behind him to signify his status in accordance with Ethiopian custom - like an "Oberritter" ( baronet), he wrote his sons Oscar and Georg back home. ${ }^{103}$

Considering the lack of travel experience of most in the German mission, the encounters with Ethiopian officials on the way had "provided the chance, for us to become familiar with the sight of an Abyssinian dignitary and Abyssinian soldiers", Friedrich wrote the Auswärtiges Amt. ${ }^{104}$ Observing his brother Felix, Friedrich wrote to Nina that "[h]e would profit much more by the journey if he had travelled more before. He would be able to compare what he sees here to other countries." His own previous cognitive framings had Ras Makonnen appear like a "refined Persian" to Rosen. ${ }^{105}$ One should not conclude that this was an entirely harmonious affair of esteem and without prejudice. Rosen thought the eating habits of the Somalis and Ethiopians "quite barbarous", as he wrote to Nina in one of his first letters. Only later did he take a liking to seeing with what elegance raw ox meat was eaten. The same hesitation and sense of strangeness was shared by the rest of the German delegation. "All was unfamiliar and odd for us", Bosch noted. But by the time the Germans arrived in Addis Ababa the

102 Felix Rosen, Gesandtschaft in Abessinien, 104-9; Friedrich Rosen to Bernhard von Bülow, 15 February 1905, Reisebericht I, A 5515, R 14915, PA AA; Ben-Dror, "Rimbaud in Harär”; Berge, Verschwundene Länder, 55-56.

103 Friedrich Rosen to Oscar and Georg Rosen, 22 January 1905, Briefe aus Abessinien, ASWPC; Martin Rücker Freiherr von Jenisch to Bernhard von Bülow, 28 December 1904, A 8995, R 14892, PA AA; Felix Rosen, Gesandtschaft in Abessinien, 124-27; Bosch, Karawanen-Reisen, 149; Fliegenwedel, 13, Sammlung Rosen I Afrika. Abessinien, LLM; Theilhaber, "Bestände Rosen Detmold".

104 Friedrich Rosen to Bernhard von Bülow, 15 February 1905, Reisebericht I, A 5515, R 14915, PA AA; Friedrich Rosen to Nina Rosen, 22 January 1905, Briefe aus Abessinien, ASWPC.

105 Friedrich Rosen to Nina Rosen, 22 January 1905, Briefe aus Abessinien, ASWPC; Friedrich Rosen to Nina Rosen, 26 January 1905, Briefe aus Abessinien, ASWPC. 
soldiers of the Gardes du Corps showed, to the pleasure of Menelik, no aversion to eating with their hands. ${ }^{106}$

The splitting of the caravan had resulted in the camels' taking a different route and arriving nearly a week later than the mission itself. This posed a problem. The camels carried the uniforms of the gardes du corps and the gifts for Menelik, and thus the mission had no choice but to camp outside the city and wait for their equipment before it could enter the city. Anything else would have been taken as an offence by Menelik, and Rosen wanted to make an impression with his uniformed soldiers. In the meantime, Rosen conducted his first meetings with Ilg, arranging the entry into the city and finding out more about the political scenery. Holtz also came to meet Rosen. ${ }^{107}$ Seeing himself, as he wrote later that year, obliged to work on Holtz's behalf as his “German compatriot”, Rosen attempted to reconcile Holtz and Ilg. Despite Ilg's severe reservations, who still felt insulted by the campaign against his person, and Holtz's brazen demand to be appointed German consul if he was to apologise to Ilg, Rosen succeeded initially in making peace between the German he was bound to support and the Swiss, on whose trust the success of his mission depended. ${ }^{108} \mathrm{~A}$ few days later Rosen wrote to Nina that "Holtz is quite a dreadful fellow, mad, ambitious, hefty and deceitful”. After Holtz refused to participate in the welcoming procession, as he had not been made consul, Rosen wrote to Mühlberg:

Die einzigen Schwierigkeiten, die ich bisher gefunden habe, hat mir unser Landsmann Holtz bereitet. Ich habe mit der größten Mühe den hier hoch angesehenen Staatsrat Ilg dazu gebracht sich mit Herrn Holtz auszusöhnen. Wenn Holtz auch nur für einen Dreier gesunden Menschenverstand besitzt, wird er diese Situation für sich und seine Auftraggeber ausnützen. Aber sein Größendünkel und seine Empfindlichkeit sind vielleicht schon zu weit vorgeschritten, und ich fürchte er wird bald an den Punkte anlangen, wo die Kunst der Diplomatie aufhört, um der des Psychiaters Platz zu machen. ${ }^{109}$

106 Friedrich Rosen to Nina Rosen, 14/15 January 1905, Briefe aus Abessinien, ASWPC; Friedrich Rosen to Nina Rosen, 20 February 1905, Briefe aus Abessinien, ASWPC; Bosch, Karawanen-Reisen, 176.

107 Felix Rosen, Gesandtschaft in Abessinien, 166.

108 Friedrich Rosen to Reinhold Klehmet, 20 July 1905, A 15271, R 14915, PA AA.

109 "The only difficulties I have so far encountered were caused by our compatriot Holtz. With much effort I have convinced the here highly regarded state secretary Ilg to reconcile with Holtz. If Holtz owns only a healthy mind worth threepence, he will take advantage of this situation for himself and his employers. But his arrogance and his sensitivity are perhaps already too advanced, and I am afraid that he will soon have reached the point, where the art of diplomacy ends to make space for that of the psychiatrist.” Friedrich Rosen to Nina Rosen, 20 February 1905, Briefe aus Abessinien, ASWPC; Friedrich Rosen to Otto von Mühlberg, 20 February 1905, A 4382, R 14914, PA AA. 
For the rest of the mission this simmering issue was of little consequence, as Ilg and Rosen got along well and Holtz left Addis Ababa before the start of negotiations - to bring the Daimler truck stuck in Dire Daua to the capital. ${ }^{110}$

The missing uniforms finally arrived and the German Sondergesandtschaft readied to enter Addis Ababa on 12 February. Dressed in gala uniform and supplied in advance with horses by the Ethiopian court, the Gardes du Corps under the direction of Eulenburg - dressed as a king's hussar - led the German procession into the capital. ${ }^{111}$ The "long blond lads", as Felix called them, were followed by the honorific mule Rosen had received from Ras Makonen, and another one sent over by Menelik just before the ceremony. Both mules were adorned in silver and embroidered bridles. Behind them rode Rosen as chief of the mission in infantry uniform, next to Ilg as the Ethiopian representative, who wore tailcoat and the diplomat's tricorn. Rosen's honour shield and lances were carried behind. Then came the other members of the German delegation in uniform or tailcoats, and finally the Somali and Ethiopian servants all dressed in khaki and with black-white-red (the German colours) aiguillettes forming the rearguard. ${ }^{112}$ Riding towards the German procession on an open field were two rows of Abyssinian soldiers in "rich garb", followed by infantry and more cavalry. At the head of the welcoming party rode general Ras Tassama, wearing a lion's mane. After dismounting, "welcome and polite phrases were exchanged following Oriental style, and introductions were done according to European custom." Continuing into the city, Ras Tassama rode on the side of Rosen, with the suites of the two men mixing. Felix was in awe: "Immer neue Massen schlossen sich an, die lebhafte Bewegung schien die Zahl zu verdoppeln. Bald wälzte sich eine ungeheure Menschenmenge rechts und links der Straße vorwärts, laufend, springend, kletternd... Und welch ein Farbenspiel!" Some 12,000 men moved towards the city accompanied by horns being tooted. Vollbrecht and Bosch were equally thrilled, and Friedrich wrote Nina that "it was altogether like a dream". ${ }^{113}$

110 Friedrich Rosen to Otto von Mühlberg, 11 July 1905, A 12285, R 14915, PA AA; Friedrich Rosen to Reinhold Klehmet, 20 July 1905, A 15271, R 14915, PA AA; Friedrich Rosen, Aufzeichnung über Arnold Holtz, 12 July 1905, A 12285, R 14915, PA AA.

111 Felix Rosen, Gesandtschaft in Abessinien, 169-74; “Menelek Receives Kaiser’s Envoy,” New York Times, 14 February 1905.

112 Felix Rosen, Gesandtschaft in Abessinien, 174; Bezirks-Kommando I. Breslau to AA, 7 December 1904, 2567 II, R 14914, PA AA; Prunkschilder, 31-33, Sammlung Rosen I Afrika. Abessinien, LLM; Pferdegeschirr und Sattel, 1-11, Sammlung Rosen I Afrika. Abessinien, LLM.

113 "Ever new masses linked together, the lively movement seemed to double the numbers. Soon a tremendous multitude of people rolled left and right of the road forward, running, jumping, climbing... and what a play of colours!” Felix Rosen, Gesandtschaft in Abessinien, 176-77; 
After being dusted down, the delegation entered the dimly lit audience hall, blinded by the bright light outside. Slowly regaining sight at the end of the hall, a throne of cushions came into focus, with emperor Menelik on top wearing "a crown made entirely of diamonds". ${ }^{114}$ Flanked by his court members, Menelik received the German delegation with Rosen delivering his greetings, while handing over a letter from Wilhelm in a rich casing: "Wir kommen, um dem geeinten und mächtigen Äthiopischen Reich die Freundschaft des großen deutschen Volkes anzutragen, das mit Abessinien in friedlichen Verkehr $\mathrm{zu}$ treten wünscht." ${ }^{115}$ Polite conversation ensued about the two countries, and their flowering and grace under their imperial leaders. Menelik took a keen interest in the Gardes du Corps standing at attention in "iron motionlessness". After a few more pleasantries the German delegation left the Negus Negesti deeply impressed and elevated by Menelik's friendliness and good humour. As Rosen would also find during later encounters, Menelik was "really very nice" and would often "step out of the reserve that has become second nature of most Oriental rulers." Leaving the hall through rows of musicians playing Ethiopian tunes and eleven canons fired, the Germans were escorted by a number of court nobles and military figures to the spacious villas that Ras Makonnen and Ras Mikael had vacated for the duration of the German guests' stay. Upon arrival at their abodes the Ethiopians started serving Tetj, a honey wine, and the Germans opened their reserves of Danziger Goldwasser, a gold flaked herbal liqueur. ${ }^{117}$

The diplomatic mission was off to a good start. During the following days the Germans called on the envoys of the European diplomatic corps, visited Ras Tassama and other generals and met with the head of the Ethiopian Church, the Abuna. These social events, mostly along European style fourteen course meals, were important to gain an understanding of the political situation in

Vollbrecht, Im Reiche des Negus, 65; Bosch, Karawanen-Reisen, 154; Friedrich Rosen to Nina Rosen, 20 February 1905, Briefe aus Abessinien, ASWPC.

114 Felix Rosen, Gesandtschaft in Abessinien, 178; Friedrich Rosen to Nina Rosen, 20 February 1905, Briefe aus Abessinien, ASWPC; Friedrich Rosen to Oscar and Georg Rosen, 15 February 1905, Briefe aus Abessinien, ASWPC.

115 "We are coming, to offer to the unified and mighty Ethiopian empire the friendship of the great German people, which wishes to enter into peaceful intercourse with Abyssinia." Friedrich Rosen to Bernhard von Bülow, 1 March 1905, A 5516, R 14915, PA AA; Felix Rosen, Gesandtschaft in Abessinien, 179.

116 Felix Rosen, Gesandtschaft in Abessinien, 180 - 81; Friedrich Rosen to Otto von Mühlberg, 20 February 1905, A 4382, R 14914, PA AA; Friedrich Rosen to Nina Rosen, 20 February 1905, Briefe aus Abessinien, ASWPC.

117 Felix Rosen, Gesandtschaft in Abessinien, 181; Friedrich Rosen to Oscar and Georg Rosen, 15 February 1905, Briefe aus Abessinien, ASWPC. 
the capital; who was in a position of influence, what were the latest plans and ambitions of those in power. ${ }^{118}$ As had already been in the air with the French government in Djibouti, one topic of local European politicking was the halted railway construction from the Red Sea to Addis Ababa due to a lack of finances, and attempts to open up the French railway concession to international investment. ${ }^{119}$ The British envoy John Harrington had together with the Egyptian government devised the creation of a national bank of Ethiopia, which should also contribute to the continuation of the railway construction.

Another goal was to create a functioning Ethiopian mint to replace the Austrian Maria Theresa Thaler, rifle bullets and salt as currency - something the government of Menelik also designed to further unify his empire and bolster his sovereignty. Harrington talked to Rosen openly about these plans, probably either desiring a German financial involvement or merely the expression of German interest as a lever for negotiations with the Italian and French representatives, who were also supposed to participate in the management and funding of the bank. ${ }^{120}$ The news of the establishment of the bank, with a starting capital of 480,000 pounds to be owned with $50 \%$ of shares by the National Bank of Egypt and another $25 \%$ by French and Italian consortiums, had that spring reached Berlin through its consulate in Cairo. Germany had not been involved in the previous planning of the bank. ${ }^{121}$ Rosen saw a chance to involve Germany in Ethiopia with the agreement of European partners and thus potentially send a collaborative signal to European politics from the periphery. Delivering concrete results to German finance was also a promising prospect. Lastly, Germany would contribute to Ethiopia's economic development in what looked like a constructive, largely Ethiopian driven initiative. It conformed to the self-understanding of Rosen and lent the mission a strategic purpose. Rather than becoming overly dependent on one of the three neighbouring powers, ensuring stable Ethiopian finances was the best guarantee for the continued independence of Ethiopia.

The meetings with the Ethiopian nobles Ras Tassama, the governor of Kaffa Ras Wolde Giorgis, the general and intimus of Taitu Dejazmatch Abbata, and another son of Ras Makonnen appear to have been of mostly social or informational nature. This may have had to do with hierarchical structure of the Ethiopian

118 Menu Russian Legation, 3/16 February 1905, Briefe aus Abessinien, ASWPC; Menu British Legation, 18 February 1905, Briefe aus Abessinien, ASWPC; Felix Rosen, Gesandtschaft in Abessinien, $190-92$.

119 Friedrich Rosen to AA, 20 February 1905, A 4376, R 14914, PA AA.

120 Friedrich Rosen to Otto von Mühlberg, 20 February 1905, A 4382, R 14914, PA AA; Friedrich Rosen to Nina Rosen, 27 February 1905, ASWPC.

121 Otto von Mühlberg to Friedrich Rosen, 8 February 1905, A 2147, R 14892, PA AA. 
government or Rosen simply not wanting to engage with any lower level court members out of a lack of knowledge about them, fear of alienating others or appearing insolent to Menelik. Nevertheless, these meetings were significant, particularly for future business deals and understanding the economic landscape. ${ }^{122}$ The meeting with Abuna Mattheos X was also mostly social, although the elderly Coptic Bishop expressed wariness about his posting away from Egypt. Aware of the Jerusalem question in the years before and the conflict between the Egyptian Copts and the Ethiopian orthodox, whose highest priests were Copts, and the recurring threat of a schism uttered by the Ethiopians, Rosen was cautious in his interactions with the Abuna, as he wanted to collaborate with Menelik and Taitu. If Felix's derision of the Abuna's corruption is any indication, the meeting did not come to any tangible results. ${ }^{123}$

Most important were the meetings with Ilg. With his unrivalled position at Menelik's court, understanding of the power structures in Addis Ababa and lay of the land generally, Ilg was sympathetic to the German mission and its goals. In his reports to the Auswärtiges Amt Rosen was clear that Ilg facilitated and ensured the functioning of the mission and helped the German to understand the workings of the country and prepare for political negotiations. The trusted Ethiopian advisor Ilg, who was since Adua beyond any suspicion of secretly working for foreign interests, provided access to the German delegation and levelled sources of cultural misunderstanding. After decades in Ethiopia and fluent in Amharic, Ilg was an easy conversation partner for the Germans and Felix later wrote that they felt entirely at home in the German speaker's house. Ilg had been peeved by the allegation of being Germanophobic, an accusation that the entire German delegation would in the aftermath of the mission try to dispel. ${ }^{124}$ Yet, while this cultural closeness, ease of communication and sympathy was useful, Ilg still acted in Ethiopian state interests. The antagonistic and manipulative Holtz had made collaboration difficult. The Rosen mission's

122 Felix Rosen, Gesandtschaft in Abessinien, 196-202; Bosch, Karawanen-Reisen, 159.

123 Friedrich Rosen to Nina Rosen, 18 March 1905, Briefe aus Abessinien, ASWPC; Felix Rosen, Gesandtschaft in Abessinien, 183.

124 Friedrich Rosen to Otto von Mühlberg, 20 February 1905, A 4382, R 14914, PA AA; Friedrich Rosen to Bernhard von Bülow, 12 March 1905, A 5517, R 14915, PA AA; Felix Rosen, "Kaiser Menelik und Seine Leute,” Berliner Tageblatt, 18 May 1905; Friedrich Rosen to Reinhold Klehmet, 20 July 1905, A 15271, R 14915, PA AA; Friedrich Rosen to AA, 20 February 1905, A 4376, R 14914, PA AA; Clapham, "Mənilək II," 923; Felix Rosen, Gesandtschaft in Abessinien, 187-90; Conrad Keller, “Alfred Ilg," Jahresberichte der Geographisch-Ethnographischen Gesellschaft in Zürich 16 (1916): XII; Conrad Keller, Alfred Ilg. Sein Leben und sein Wirken als schweizerischer Kulturbote in Abessinien (Frauenfeld: Huber, 1918), 240. 
interests in internationalised trade agreements, scientific exploration and Germany as a factor for balancing out the other European powers was an opportunity for Ethiopia that Ilg could connect neatly with his own interests.

Another week later, the remainder of the caravan arrived with the gifts, and a formal audience with Menelik was held on 19 February. The German delegation rode to the audience hall of Menelik in great gala costumes. As the Gardes du Corps stood to attention, Menelik gave the Germans a "lively welcome”. After Rosen decorated Menelik with the Großkreuz des Roten Adlerorden, leaving a deep impression with all Ethiopians and Germans present, a goldenframed life-sized picture of Kaiser Wilhelm in uniform was unveiled at a sign of Rosen. Felix noted: "Non-compliant with etiquette [Menelik] left his throne and rushed to the picture, bursting out "It is as if I could talk with him."”125 As Menelik sat down again every member of the German delegation handed the emperor a gift. While the photographs of Berlin's and Potsdam's castles found as much grace in the eyes of Menelik as the silver cutlery, silk and other gifts, Flemming had the pleasure to hand over a stack of books written in Amharic and Ge'ez that had been printed in Germany over the last few hundred years. On top sat Flemming's own publication.

Diese Gabe bereitete dem Negus besondere Freude, und er durchblätterte sofort Buch für Buch, lobte die Klarheit und Gleichmäßigkeit der Typen und schlug hin und wieder eine Lieblingsstelle nach. Sichtlich machte es großen Eindruck auf ihn, zu sehen, daß die deutsche Wissenschaft sich längst mit der Sprache und Literatur seines Landes beschäftigt hatte, bevor noch an offizielle Beziehungen zwischen beiden Staaten gedacht worden war. Der Negus gab auch sogleich Befehl unsrem Reisegenossen seine Studien über amharische Manuskripte in jeder Weise zu erleichtern und ihm vor allen Dingen die kaiserliche Bibliothek im Gebi und die Büchersammlungen in den Kirchen der Stadt und Antottos zugänglich zu machen. ${ }^{126}$

125 Friedrich Rosen to Bernhard von Bülow, 1 March 1905, A 5516, R 14915, PA AA; Felix Rosen, Gesandtschaft in Abessinien, 253.

126 "This gift brought the Negus special joy, and he immediately leafed through one book after the other, praised the clarity and the evenness of the types and looked up some of his favourite passages. Visibly, it made a big impression on him to see that German scholarship had for long engaged with the language and literature of his country, long before official relations between both states were even thought about. Straightaway, the Negus gave order to facilitate the studies of Amharic manuscripts of our travel companion in every way and to grant him access to the imperial library in the Gebi and the book collections in the churches of the city and in Entoto." Felix Rosen, Gesandtschaft in Abessinien, 254-55. 
The German gesture gained in meaning when considering that the British had plundered 1,000 ancient manuscripts in Ethiopia during a punitive expedition led by Robert Napier in $1867 .^{127}$

As the reception came to a close, Rosen inquired to see Empress Taitu, as the German Kaiserin had sent gifts for her. Likely this was pre-arranged by Ilg. A direct request for an audience would have been against etiquette, but despite this being an "unusual request" Menelik had no objections. Finding Taitu in a different hall, the delegation was asked to sit next to the Empress. Photographs of Kaiserin Auguste Viktoria and the German court's princes and princesses were handed over, together with silks and silverware picked out by Nina. ${ }^{128}$ A German altar piece chosen by the German royal couple found particular favour with Taitu. It was above all that it had been the Kaiser and Kaiserin personally, who had made the choice, that pleased the Ethiopian rulers. Signalling that the German court and government knew that Taitu and Menelik took an interest in church matters, and sending a gift that nodded to the common Christianity of the two royal houses, created a symbolic common ground and projected goodwill. As Bosch observed, the conversation with Taitu broached church affairs, a matter that Rosen "knew very well. He was thus in a position to conduct with the Empress a for her very interesting conversation about Jerusalem, churches and other topics - of course not failing to leave an impression". ${ }^{129}$

The gifting was followed by feasting. Organised weekly or biweekly, on the day of Gebi the Negus Negesti received some 8,000 people in his hall. Intended to popularise the ruler, all visitors joined in a large meal. ${ }^{130}$ The Germans were seated with the Negus on a podium, but sat separately along a European table. In a show of favour, the Gardes du Corps were asked to sit with the Ethiopian nobles. Next to Ethiopian food, strong Ethiopian wine, also Bordeaux and champagne were served and after the third course a curtain surrounding the podium was lifted and several thousand people streamed into the hall to eat. While Felix was not entirely at ease, feeling reminded of a "feeding in a zoological garden" and finding the food too spicy, Friedrich was mostly taken by the "kindness and greatness of Kaiser Menelik" and wrote to Nina that "[i]t was a wonderful sight as [the Ethiopians] sliced off their raw meat and ate it cutting it off in front of their lips with a knife. The Negus is quite in love with the Gardes du

127 Ferguson, Empire, 176-79.

128 Friedrich Rosen to Nina Rosen, 20 February 1905, Briefe aus Abessinien, ASWPC; Felix Rosen, Gesandtschaft in Abessinien, 255.

129 Friedrich Rosen to Bernhard von Bülow, 1 March 1905, A 5516, R 14915, PA AA; Bosch, Karawanen-Reisen, 136.

130 Felix Rosen, Gesandtschaft in Abessinien, 257. 
Corps whom he let eat with him on the reserved platform. We spent many hours in that hall and were half dead when we came home."131

A few days later Menelik carried out his return visit to the German camp. Out of politeness to the Germans he arrived on horseback rather than on the traditional mule. Rosen found, "[i]t was a grand sight. He rode a splendid big warhorse all covered with gold trappings and looked most imposing with a spear in his hand. His suite was equally picturesque.” Honey cake, marzipan and Danziger Goldwasser were served. Menelik liked the marzipan best. ${ }^{132}$ Under the direction of Eulenburg the Gardes du Corps performed a lancing joust for the entertainment of Menelik, the blond lads apparently putting up a good show: "The handsome tall people in their stately uniform impressed everywhere in Ethiopia, where everyone is a soldier, and exemplified moreover the discipline of which our fatherland can be proud." The Italian chargé d'affaires Giuseppe di Felizzano Colli confirmed to Rosen that Menelik felt "très flatté" by Wilhelm having sent his elite unit with the mission to his court. ${ }^{133}$ Menelik returned the favours by presenting medals, national costumes in gold, weapons, elephant tusks and church items for the German imperial couple. Rosen received another honour shield with lances and the medal of the Ethiopian Star. On the following day Menelik sent a mule and a horse each for Rosen and Eulenburg. Ever interested in riding animals, Rosen was very pleased with what he had received. ${ }^{134}$

Only after the exchanges of gifts had passed amicably, with both sides having recognised each other's honour and expressed their respect, did the negotiations between Rosen and Menelik begin formally. ${ }^{135}$ The first topic of discussion was the treaty establishing diplomatic and trade relations. This was a relatively simple affair. Both countries had already beforehand made it known that a treaty should be agreed upon. The form of the treaty then was a near one-to-one copy of the treaty Ethiopia had signed with the US in 1903, including elements from the British treaty from 1897. The contract was largely reciprocal. Freedom and security of movement, residence, trade, labour and property were guaranteed to the citizens of both countries, but it was singled out that German companies should have access to all forms of infrastructure in Ethiopia, a provision that

131 Friedrich Rosen to Bernhard von Bülow, 1 March 1905, A 5516, R 14915, PA AA.

132 Friedrich Rosen to Nina Rosen, 27 February 1905, ASWPC.

133 Friedrich Rosen to Bernhard von Bülow, 12 March 1905, A 5517, R 14915, PA AA.

134 Friedrich Rosen to Oscar and Georg Rosen, 15 February 1905, Briefe aus Abessinien, ASWPC.

135 Steven Kaplan and Dirk Bustorf, “Gifts," in Encyclopaedia Aethiopica. A Reference Work on the Horn of Africa, vol. 2, Siegbert Uhlig (Wiesbaden: Harrassowitz, 2005), 791-92. 


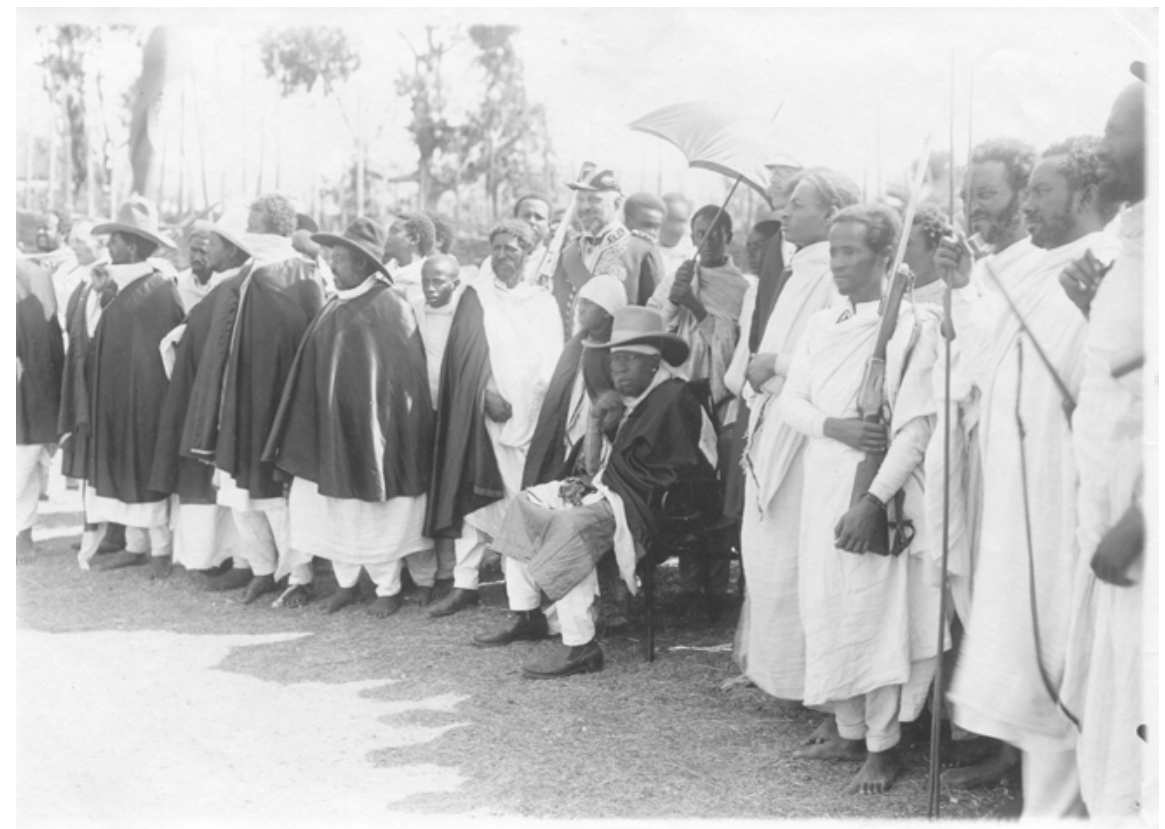

Fig. 4.2. Menelik II (seated) and Friedrich Rosen inspecting the Gardes du Corps in Addis Ababa, March 1905.

was not included for Ethiopians in Germany. ${ }^{136}$ These elements were by and large the same as in the US treaty, but Rosen had pressed for the sharpening of the language guaranteeing the security of citizens. An addition in the German treaty was a clause guaranteeing Germany "most favourite nation" status, that is, any trade facilitation or customs reduction awarded to any other country should also be applicable to Germany. Wilhelm later expressed in a letter to Menelik his appreciation of Germany being granted this status. ${ }^{137}$

Excluded was a clause of the US and British treaties that stipulated that jurisdiction was held by the country of residence. As Rosen reported to Berlin, this was the only sticky point in the negotiations. ${ }^{138}$ Menelik and Ilg were surely aware of how the jurisdiction system of the capitulations was used by European powers to undermine the sovereignty and independence of the Ottoman Empire, Iran and other countries, by essentially granting to European citizens an extra-

136 Tafla, Ethiopia and Germany, 106.

137 Wilhelm II to Menelik II, 3 July 1905, A 10721, R 14915, PA AA; Bernhard von Bülow, "DeutschÄthiopischer Freundschafts- und Handelsvertrag," Introduction to Treaty, 1906, R 14894, PA AA. 138 Friedrich Rosen to AA, 27 February 1905, A 3220, R 14914, PA AA. 
judicial status in their dealings there. Clarifying jurisdiction as in the US-Ethiopian treaty would have meant that German citizens could be judged by Ethiopian courts. Although Felix's report dispelled some of the myths prevalent in previous European travel reports over the abject brutality of the Ethiopian legal system, Rosen preferred not to have Ethiopian jurisdiction over German citizens mentioned in the treaty. The complete absence of the question of jurisdiction was an expression of the difficulty of finding an acceptable formula. The issue was left open. Future cases would be dealt with on the diplomatic level. Given the still relatively low numbers of Germans in Ethiopia and vice versa, this was a sensible compromise for the time being.

As in the US treaty, Ethiopia and Germany agreed to grant each other the right to send resident diplomats, something important for the signalling of mutual recognition and for Germany to support its business interests in Ethiopia. ${ }^{139}$ In the middle of the meetings Rosen wired to Berlin:

\footnotetext{
"Kaiser Menelik ist politisch einsichtig genug, um zu begreifen, daß seine Selbstständigkeit um so gesicherter wird je mehr Mächte in Äthiopien interessiert sind und daß die größte Gefahr für ihn darin besteht, daß durch Großbauten und Konzessionen politisch Interessensphären in seinem Reiche geschaffen werden.”
}

Rosen told Menelik that Germany wanted to be included in all future international enterprises to prevent Ethiopia from being carved up by the neighbouring powers. According to Rosen's report, Menelik answered that it would be possible for Germany to participate in the new Ethiopian national bank and that he was interested in involving Germany in the completion of the railway from Djibouti to Addis Ababa. While this was music in Rosen's ears, he answered that Germany needed to act in "complete restraint" as long as any other European power held a legal concession. However, should Menelik internationalise the railway, Germany would gladly participate with financial provisions. ${ }^{140}$ Rosen suggested that an international consortium could be established, or Menelik could take back the concession and lead construction himself with the help of international finances and hire foreign industrial companies. Menelik signalled

139 Bernhard von Bülow, "Deutsch-Äthiopischer Freundschafts- und Handelsvertrag,” Introduction to Treaty, 1906, R 14894, PA AA; Felix Rosen, Gesandtschaft in Abessinien, 244-45; Bosch, Karawanen-Reisen, 159.

140 "Emperor Menelik is insightful enough to realise that his independence is safer the more powers are interested in Ethiopia, and that the greatest danger is for him that through large building enterprises and concessions political spheres of interest are created in his empire." Friedrich Rosen to AA, 10 March 1905, A 4257, R 14914, PA AA. 
agreement to the suggestion, and as Rosen wrote back to Berlin, Ilg began talking with the French representative Léonce Lagarde about the matter before the departure of the German mission. Rosen also spoke with Lagarde, who apparently received his suggestion of German financial support for the dying railway project with “animated satisfaction”. On 12 April, Ilg wrote Rosen that Menelik had told the powers represented in Addis Ababa that he intended to internationalise the railway. ${ }^{141}$ An issue on which Lagarde was more hesitant, but found Harrington's support, was the establishment of the Ethiopian state bank. In conversations with Harrington and Colli, Rosen received agreement that a German banking consortium could be integrated into an international funding group of the bank. Menelik suggested German involvement on the administrative board of the bank. ${ }^{142}$

In this back and forth, two notions were central. Menelik thought of the Germans as a good partner in railway construction, as they had a track-record with the Ottomans: build a railway, but without territorial ambitions. Rosen thought of Menelik as someone who knew how to use his power and was able to deliver, also against Europeans and their legal contracts, as he had demonstrated with his abrogation of the Treaty of Wuchale. Ilg, who was present at all negotiations, helped along. Germany was late to the Ethiopian show, but mutual interests were clear on both sides. As Felix reported, his brother "became ever more convinced, to stand in front of an immensely intelligent prince, who also grasped such economic ideas with ease, which must have been completely beyond his reach before." ${ }^{143}$ It is unclear if Menelik allowed Rosen to make the suggestions he did not want to utter himself, or if Rosen perhaps overstated his diplomatic acumen by a notch when talking with his brother. However, the mutual sympathy and trust that had been built up in the weeks of ceremonies, gift-giving and socialising on even par rendered the negotiations an agreeable undertaking. Both sides saw that they would profit from collaboration and thus the scope of discussions increased.

In conversations on the side Rosen and Menelik talked about improving saddles for pack animals along the lines caravans in the Middle East were equipped with and how to improve the country's forestry and maintain its agricultural productivity. ${ }^{144}$ Rosen also told Menelik about German excavations in the Ottoman

141 Friedrich Rosen to AA, 2 May 1905, A 5517, R 14915, PA AA.

142 Friedrich Rosen to AA, 24 February 1905, A 3220, R 14892, PA AA; Friedrich Rosen to AA, 18 March 1905, A 4720, R 14892, PA AA.

143 Felix Rosen, Gesandtschaft in Abessinien, 265.

144 Felix Rosen, Gesandtschaft in Abessinien, 225, 284; Felix Rosen, Charakterpflanzen des abessinischen Hochlandes (Jena: Gustav Fischer, 1909), 25/3, 26/1, 28/1-2. 
Empire and how Germany had there participated in the quest to establish the "empirical historicity of the Old Testament". The prospect of adding Ethiopian Christianity to the overall salvation history excited the self-declared descendant of Solomon, who sought legitimacy from an Ethiopian national-religious past. Archaeological findings promised to expand Ethiopian historical sources in manuscripts, paintings and oral traditions and lend scientific credibility. ${ }^{145}$ Only a few months earlier human bones, claimed to be of Menelik I, had been excavated outside Aksum. They were laid to rest at a cathedral in the holy city of Aksum, "thus promoting one of the founding myths - the Israelite origins of Ethiopian civilisation." 146 On 26 February the British legation organised a gymkhana, a sportive festival, with horse and sack races, lancing duels and tent-pegging. In tent-pegging horsemen ride towards a small target on the ground, which they pierce with a lance. In this European-Ethiopian mixed event the participation of the Gardes du Corps was a great show. Rosen, not one to miss showing off his riding skills, borrowed Harrington's horse, as his own had a limp, and successfully pegged three tents under the eyes of Menelik. ${ }^{147}$ When Rosen found Menelik in particularly good spirits on the next day, he asked the emperor straight out if he would not give Germany the excavation rights at Aksum. Menelik agreed, and Rosen was mighty pleased with himself. ${ }^{148}$

Zitelmann and Daum have analysed how with considerable diplomatic skill Rosen would in the aftermath of the mission come to orchestrate the establishment of the Deutsche Aksum Expedition under his friend from Jerusalem Enno Littmann, with the Kaiser paying the expenses out of his own pocket and Littmann being released out of his contract with Princeton University. ${ }^{149}$ It is unlikely that Rosen had pre-meditated requesting excavation rights for Germany before

145 Felix Rosen, Gesandtschaft in Abessinien, 266; Zitelmann, "Politische Einbettung der Aksum-Expedition,” 114; Daum, “Rosen, Littmann, Aksum,” 90.

146 Zitelmann finds in Littmann's diary from 15 January 1906 an entry suggesting that Rosen was responsible for the excavation of the bones of Menelik I. This is not confirmed by Fiaccadori's chronology of events, as Rosen had not been in Aksum at the time of the digging in the winter of 1904/5. Rosen only arrived in Aksum in late April. Gianfranco Fiaccadori, "Mənilək I," in Encyclopaedia Aethiopica. A Reference Work on the Horn of Africa, vol. 3, Siegbert Uhlig (Wiesbaden: Harrassowitz, 2007), 922; Zitelmann, "Politische Einbettung der Aksum-Expedition,” 115. 147 Friedrich Rosen to Nina Rosen, 27 February 1905, ASWPC.

148 Friedrich Rosen to Nina Rosen, 6 March 1905, Briefe aus Abessinien, ASWPC; Friedrich Rosen to AA, 10 March 1905, A 4257, R 14892, PA AA.

149 Zitelmann, "Politische Einbettung der Aksum-Expedition"; Zitelmann, "Littmann"; Daum, "Rosen, Littmann, Aksum”; Enno Littmann, comp., The Library of Enno Littman 1875-1958. Professor of Oriental Languages at the University Tübingen. With an Autobiographical Sketch (Leiden: E.J. Brill, 1959), XVII. 
the mission. In the scientific estimation of the possible value of the Rosen mission submitted by Harnack and the culture ministry, mention of Aksum is made, but nothing was said of excavations of any sort. In a proud letter to his wife Rosen wrote that the excavations ought to please the Kaiser and Harnack. ${ }^{150}$ Rosen was conscious of potential political ramifications such an excavation could have internationally and in scholarly circles. He asked the Auswärtiges Amt to keep the matter confidential for the time being and that the Negus would expect a telegram from the Kaiser, thanking him for allowing Germans to excavate his holy city. The Kaiser agreed that "better not inform savants yet, they chatter like old women". While Rosen sought to further ingratiate himself with his own sovereign and the scholarly circles around him, his scoop had also made him powerful enough to navigate the still junior scholar Littmann to the head of the Deutsche Aksum Mission, bringing Littmann back from his American "exile" and eventually resulting in a call to Straßburg university, where Littmann would replace the retired Orientalist eminence Theodor Nöldeke. ${ }^{151}$

The first discussion between Rosen and Menelik had, however, been on Jerusalem. The Negus and "especially the Empress" expressed their wish for Germany to help Ethiopia with pursuing its interests over the Deir es-Sultan monastery in Jerusalem. Rosen wired back to Berlin that he thought this "inopportune", as this would pitch Germany against England, which represented Coptic interests in Jerusalem as rulers of Egypt. With the backing of the Auswärtiges Amt and in a relapse to previous German inaction, Rosen replied that Ethiopia should work with Italy on finding an arrangement on this matter. ${ }^{152}$ But as Tafla notes, Rosen accepted a document on the matter by Taitu, which he only disclosed several months after his return in Berlin. ${ }^{153}$ This is corroborated by a request made by Ethiopian envoy Mashasha to the German consul in Jerusalem in the summer of 1905. Mashasha reminded the Germans that Menelik had given Rosen proof of the Ethiopian claims and demanded that Germany should now become active on its behalf. Already on his stop in Constantinople in April, Mashasha had approached the German legation to find support for its claims with the Ottoman

150 Friedrich Rosen to Nina Rosen, 6 March 1905, Briefe aus Abessinien, ASWPC.

151 Friedrich Rosen to AA, 10 March 1905, A 4257, R 14914, PA AA; Littmann, The Library of Enno Littman 1875-1958, XVII; Actes du XIV Congrès international des Orientalistes. Alger 1905. Première Partie (Paris: Ernest Leroux, 1907), 66.

152 Friedrich Rosen to AA, 23 February 1905, A 3156, R 14914, PA AA; Friedrich Rosen to AA, 23 February 1905, A 3156, R 14909, PA AA; Friedrich Rosen to AA, 23 February 1905, A 3156, R 14892, PA AA.

153 Tafla, Ethiopia and Germany, 112. 
Sultan. ${ }^{154}$ Rosen had written to Berlin that he would evade the topic and remain ambiguous. That ambiguity may well have enabled a successful continuation of the negotiations with several tangible results. But without finding any other allies in their quest for gaining Deir es-Sultan, German ambiguity was enough for Ethiopian representatives to come back to Germany on the matter for another two years.

Considering Menelik's infatuation with the Gardes du Corps, it is important to note the lack of military results. Krupp had approached the Auswärtiges Amt on the suggestion of Holtz before the beginning of the mission. Krupp inquired again in late February, apparently without having heard back from Rosen about their offer to send a sample piece of mountain artillery, at which point Rosen wrote Bülow that weapons were too sensitive a matter:

Bis jetzt ist die Kaiserliche Mission weder bei den Abessiniern noch bei den hiesigen diplomatischen Vertretungen dem geringsten Mißtrauen begegnet. Das Vertrauen in die Ehrlichkeit unserer rein wirtschaftlichen Bestrebungen würde jedoch sofort schwinden, wenn die Vertreter der drei Großmächte bemerkten, daß wir dem Lande Kriegswaffen lieferten, die im Ernstfalle nur gegen sie gerichtet werden könnten.

Even if the Ethiopian government was interested in weapons, such cargo would not be allowed to pass through the surrounding French, Italian or British territories. As he wrote to Bülow, Rosen had deliberated with Ilg on the matter and had finally come to the conclusion that he would not bring up weapons in his conversations with Menelik. ${ }^{155}$ In an attached letter to Krupp, Rosen explained as much, with an emphasis on the Ethiopians not being able to afford artillery, but noting that Ilg had received the album with Krupp's repertoire. He would be in touch should things change.

While Rosen was negotiating, Flemming looked for manuscripts in churches and monasteries, Vollbrecht treated people, including Ras Makonen and Taitu, the trade staffers studied the markets and made connections among local merchants, and Eulenburg made sure the Gardes du Corps followed Prussian drill. Felix looked for plants and ethnographical items, writing back to his funders

154 Edmund Schmidt to Bernhard von Bülow, 28 July 1905, A 15354, R 14893, PA AA; Adolf Marschall von Bieberstein to Bernhard von Bülow, 17 April 1905, A 6750, R 14892, PA AA.

155 "Until now the imperial mission has not been met with the least suspicion by the Abyssinians or the diplomatic representations here. The trust in the honesty of our purely economic aspirations would, however, immediately wane should the representatives of the three great powers notice that we are delivering war weapons to the country, which can in a case of emergency only be directed against them.” Friedrich Rosen to Bernhard von Bülow, 2 March 1905, A5011, R 14892, PA AA. 
that "skulls are not purchasable. Taking photographs of unclothed people is lifeendangering". ${ }^{156}$ As the Germans became known for wanting to study everything, they were granted the wish to take along an Ethiopian scholar to Germany. Aleka Tayye, a scholar from Gondar, would become the SOS's first teacher of Amharic, with the Orientalist Eugen Mittwoch as his first student. ${ }^{157}$ Over the last weeks, Felix focused on assembling the electricity machine that the Germans had brought with them. Developing considerable eagerness and visited by Menelik and Ras Tassama several times, Felix eventually got the machine going with the help of a mechanic from the Austrian delegation that had just arrived in the Ethiopian capital. The generator, a first in Addis Ababa, was to power a Röntgen $\mathrm{x}$-ray machine, which the mission had brought along as well. During one of the last evenings the generator was used to power a light show in the city, bringing the German mission to a glamorous end. ${ }^{158}$

Rosen's report on the achievements of the mission evoked in Wilhelm a congratulatory "Bravo Rosen! Hat seine Sache ganz vortrefflich gemacht. Soll hoch dekoriert werden." 159 On the way back via Gondar, Aksum, Adua and Eritrea, the news of the Kaiser's landing at Tangier reached Rosen. The mail bag was emptied on the pedestal of an ancient obelisk in Aksum on 1 May. Rosen "found al-

156 A German ethnographic manual from 1904 instructed travellers how to collect skulls and other items if this did not provoke "vexation". Felix von Luschan, "Anleitung für ethnographische Beobachtungen und Sammlungen in Afrika und Ozeanien," Zeitschrift für Ethnologie 36, no. Sonderabdruck (1904): 122; Felix Rosen to Felix von Luschan, 16 March 1905, RO Afr. R., PA EMB; Johannes Flemming, "Die neue Sammlung abessinischer Handschriften auf der Königlichen Bibliothek zu Berlin,” Zentralblatt für Bibliothekswesen 23 (1906): 8; Vollbrecht, Im Reiche des Negus, 61-121.

157 Enno Littmann, “Eugen Mittwoch 1876-1942," in Ein Jahrhundert Orientalistik. Lebensbilder aus der Feder von Enno Littmann und Verzeichnis seiner Schriften zum achtzigsten Geburtstage am 16. September 1955, Rudi Paret, Schall, and Anton (Wiesbaden: Harrassowitz, 1955), 130.

158 Rudolf Agstner, “Les relations entre l'Éthiopie et l'Autriche," in Les relations entre l'Éthiopie et les nations étrangères. Histoire humaine et diplomatique (des origines à nos jours), Lukian Prijac (Berlin: Lit, 2015), 28; Felix Rosen, Gesandtschaft in Abessinien, 278-83; Friedrich Rosen to Nina Rosen, 18 March 1905, Briefe aus Abessinien, ASWPC; Friedrich Rosen to Nina Rosen, 15 March 1905, Briefe aus Abessinien, ASWPC.

159 "Bravo Rosen! Has done his job splendidly. Shall be highly decorated.” Rosen was decorated with the highest honour of Ethiopia. As Gehring-Münzel noted, his German decoration was second rate. Internal Note, 15 March 1905, A 4257, R 14914, PA AA; Friedrich Rosen to AA, 10 March 1905, A 4257, R 14914, PA AA; Ursula Gehring-Münzel, "Unser Kriegstrommeln schweigen seit Monden. Der Wein kam aus dem Borchardt: Hundert Jahre deutsch-äthiopische Freundschaft," Frankfurter Allgemeine Zeitung 41 (18 February 2005): 46; Menelik II to Wilhelm II, 16 March 1905, A 10721, R 14915, PA AA; Friedrich Rosen to Nina Rosen, 15 March 1905, Briefe aus Abessinien, ASWPC; Menelik II, Ehrenstern von Äthiopien für Friedrich Rosen, 7 February 1905, ASWPC. 
ways only the word Morocco", accompanied by telegrams congratulating him on his appointment as envoy to Tangier. "A sense of vertigo, like when one stands at the edge of a high vertical cliff, would not leave me", Rosen remembered. ${ }^{160}$

In Eritrea then, a letter from the Auswärtiges Amt announced that Holtz had arrived in Berlin and had anonymously published an article with the nationalist and pro-colonialist Tägliche Rundschau. He derided the German mission, attacked Eulenburg and Rosen personally and clamoured national disgrace as Holtz was excluded from deals and Germany collaborated with the alleged Francophile Ilg. ${ }^{161}$ Considering how badly the German mission had gone for Holtz, this was not surprising. Moreover, with the mission under Rosen keeping its exploits close to its chest for fear of alienating international public opinion, Holtz could credibly argue that Germany had not reached any concessions, but had fallen for French diplomatic machinations. Mühlberg instructed Rosen to gather material in case a rebuttal should become necessary. But Felix shot back first in an article defending Ilg: "In truth his party is that of his sovereign, and his enemies are those Europeans, who want to obtain unreal profits in Ethiopia. And of those there are unfortunately many." In a thinly veiled description, Felix described how "a European" had requested a gold mining concession from Menelik in a region where there were no gold deposits. As Menelik laughed while granting the request, the European claimed that he wanted the concession on paper only to get further funding from an ill-informed syndicate in far-away Europe. ${ }^{162}$

As the crisis over Morocco came to a head, Rosen returned via Cairo, where he found the British representative Lord Cromer receptive to the idea of German inclusion in Ethiopia's National Bank, which would receive half its funding from Egypt. ${ }^{163}$ With the go-ahead from London, German banks were invited to partake at a moderate level in the shares and a German banker was appointed to the administrative board of the newly established bank alongside British, Ethiopian, French, and Italian representatives. Cromer attached little significance to the bank itself. He had only invested himself in the matter "as there was at the moment enough 'cause of friction' between the great powers, and that he saw it as his duty, if ever in his power, to remove all causes for alienation." ${ }^{164}$ With the

160 Friedrich Rosen, Auswärtiges Amt. Marokkokrise, 125-26.

161 A. J., "Die deutsche Mission in Abessinien,” Tägliche Rundschau, 3 May 1905.

162 Felix Rosen, "Kaiser Menelik und Seine Leute.”

163 Friedrich Rosen to AA, 18 May 1905, A 8489, R 14893, PA AA; Friedrich Rosen, Auswärtiges Amt. Marokkokrise, 127.

164 Martin Rücker Freiherr von Jenisch to Bernhard von Bülow, 2 June 1905, A 9821, R 14893, PA AA. 
Morocco crisis on everybody's mind, the attempt of Anglo-German rapprochement via the periphery went largely unnoticed.

As Rosen returned to Berlin, Ethiopia quickly moved out of his focus, as he was sent to Paris to prepare the Algeciras conference and was slated to be posted to Tangier. In an interview Rosen gave to the New York Times, he praised Menelik for his "sound morals and excellent principles, even according to the European standard" and recounted that Menelik believed he was descended from King Solomon and the Queen of Sheba. ${ }^{165}$ Rosen hardly found any time to proofread Felix's report of the mission and was beset by Holtz's continued lobbying. ${ }^{166}$ Only the Aksum excavation Rosen arranged over the summer, reminding and pushing the Auswärtiges Amt and the Kaiser to act quickly and to see a delegation headed by Littmann on its way before Menelik had forgotten his promise. The excavation deal had not been put into writing. ${ }^{167}$ With German policy in Morocco becoming more aggressive, Rosen announced as new envoy in Tangier on the way back from Ethiopia, and Holtz feeding the German colonialist press the story that the German mission had failed in achieving preponderance in Ethiopia, in the international press the Rosen mission was in the immediate aftermath regarded as a "fiasco" of German expansionist policy. ${ }^{168}$ With a group of German traders arriving in Ethiopia from the Levant less than a year later, accusations were levelled that Germany had been in it for political gain all along and Ethiopia was undergoing "Germanisation". ${ }^{169}$ At the same time, the signing of the BritishFrench-Italian tripartite agreement in 1906, establishing zones of influence in Ethiopia, without any German mention or say, effectively brought the drive for

165 The article paraphrased Rosen. "Envoy Found Menelik an up-to-Date Ruler. German Minister's Report of Visit to Moroccan Court. King Wears American Hat. Declares He is a Jew and Descendant of Solomon and the Queen of Sheba," New York Times, 12 June 1905.

166 Felix Rosen to Felix von Luschan, 8 January 1906, RO Afr. R., PA EMB; Reinhold Klehmet to Friedrich Rosen, 1 July 1905, A 11556, R 14915, PA AA; Friedrich Rosen, Aufzeichnung über Arnold Holtz, 12 July 1905, A 12285, R 14915, PA AA; Friedrich Rosen to Reinhold Klehmet, 20 July 1905, A 15271, R 14915, PA AA.

167 Friedrich Rosen to Bernhard von Bülow, 21 August 1905, A 14894, R 14915, PA AA; Friedrich Rosen to Menelik II, 13 October 1905, A 11187, R 14915, PA AA; Friedrich Rosen to Felix Rosen, 28 September 1906, Felix Rosen, ASWPC; Littmann, "Rosen,” 76.

168 "L'Allemagne en Abyssinie," Journal du Caire, 11 May 1905; "German Mission’s Fiasco," Daily Mail, 25 May 1905; "Egypt and Abyssinia,” Egyptian Gazette, 2 June 1905.

169 “Abessinien,” Kölnische Zeitung, 8 June 1906; “Abessinien,” Münchener Neueste Nachrichten, 17 June 1906; “Les Allemands en Abyssinie,” Le Matin, 17 June 1906; Wilfrid Malleson, Summary of Principal Events in 1907, L/PS/20/211, BL IOR. 
internationalisation and German economic-political engagement coupled with Ethiopian territorial integrity to an end. ${ }^{170}$

Although Ethiopia had rapidly developed its economy and proven itself as a sovereign state in the international system in the years before, Rosen still represented a Germany that was palpably more powerful. Germany's power rested on its economic strength, technological advances, and integration into a transnational European system of knowledge and political dominance, which were difficult to access for Ethiopia. Germany entered the negotiations with a distinct advantage, as it could draw on the bodies of knowledge of the French, Italian, and British representatives - information, no matter how distorted, that was translatable into bargaining coins. At the same time, this European context constrained the negotiation positions that Germany could occupy. Sales of weapons, singlecountry concessions for mining, railways or banks were off the table. In Rosen's relations with the European envoys, he depended on their good will to achieve German interests and ran the danger of becoming a pawn in their hands. It was in this context that Ethiopia was a negotiation partner rather than an adversary.

Ethiopia was not powerless, even if its power did not extend much beyond its immediate borders, as the continuous Jerusalem affair demonstrated. In the Horn of Africa, the modernist-nationalist alliance Menelik had forged out of different Ethiopian, Somali and Galla leaders, and with the assistance of a few loyal Europeans, was a force to be reckoned with. Similar to the US before, Germany and its interests fit well into Ethiopia's goals of modernisation and balancing out the other Europeans. With Germany and Ethiopia cut off from direct naval contact, the scope of goals to be achieved were limited, as was clear for Rosen and Ilg from the beginning. Daum suggesed that Rosen and his orchestration of a scientific mission that aimed at learning was an example of Rosen using his diplomatic acumen benevolently. This was particularly the case with the excavations in Aksum, which were carried out mostly for the purpose of allowing Ethiopians to connect to a positive and unifying national identity. ${ }^{171}$ As Zitelmann showed, this was a modelling of an Ethiopian nation-state along the lines of German statism, with "empires mirroring each other". ${ }^{172}$ However, while a mutual scientific or knowledge-seeking spirit played a large role in the months the German mission spent in Ethiopia, it was only the circumstances of the relative irrelevance of Ethiopia in European power politics and Germany's constrained role in the Horn of Africa that allowed for this emphasis on learning from each other.

170 “England, France and Italy in Abyssinia," New York Times, 29 July 1906.

171 Daum, "Rosen, Littmann, Aksum," 91-92.

172 Zitelmann, "Politische Einbettung der Aksum-Expedition,” 116. 
Though meaning different things for each side, learning was one way to engage that could open up other possibilities of collaboration. This worked out initially for both sides, but very quickly, with Germany tarnished due to the Morocco crisis, this new-found friendly relationship became harmful to Ethiopia, with the press already reporting in the fall of 1905 that the initiative by Menelik to internationalise the railway had been orchestrated by Germany and the US to countervail British, Italian and French influence. ${ }^{173}$ After the in retrospect fantastically harmonious Rosen mission, German ambitions were looked upon with suspicion by European circles, and with the failing of Menelik's health and his subsequent demise the Aksum excavations also lost in significance. The success of the Sondergesandtschaft and the negotiations for both sides in early 1905 were thus primarily caused by a confluence of interests that emphasised cooperation and promised to be beneficial without too many dangers attached.

Knowledge only came into the equation as a determining factor during the mission and the negotiations itself and held little prior significance. Rosen's Oriental knowledge was a knowledge of the Arabic, Turkish and Persian worlds and he had no significant understanding of Ethiopia or the region. But Arabic was beneficial and Rosen's Oriental knowledge was useful in the sense that he brought with him a form of tolerance to cultural difference, allowing him to mitigate conflicts and prevent situations to get out of hand. Despite often feeling entirely foreign, the Germans all appear to have enjoyed the mission, even the military figure Eulenberg whom Rosen was at first most hesitant about. The reception by Somalis and Ethiopians along the way, even if mostly recorded in German sources, appears to show that this willingness to be on par was appreciated. ${ }^{174}$ All of this allowed for the delegation to arrive in Addis Ababa in the first place, for its members to acclimatise and appreciate their surroundings, and to a degree overcome the lack of language abilities. Rosen's willingness to engage in the rules of Ethiopian etiquette and order his entourage to do so as well was significant for creating a positive environment conducive for negotiations.

This was especially the case as Holtz had damaged the German reputation in Ethiopia. His compatriot was not only the main hindrance he encountered in Ethiopia, but Rosen disliked the man, who so adamantly presented everything he disliked. Ill-tempered, unable to speak Amharic after years there, and unappreciative of Ethiopian culture and customs, Holtz was nominally closer to Rosen in culture - with the key difference that Rosen appreciated Ethiopia. ${ }^{175}$ With Ilg,

173 “Menelik gegen England," General Anzeiger Frankfurt, 27 September 1905.

174 Friedrich Rosen to Nina Rosen, 26 March 1905, Briefe aus Abessinien, ASWPC.

175 Felix Rosen, Gesandtschaft in Abessinien, 211, 250-51. 
however, Rosen felt a sense of kinship. Of European origin, conversant in Amharic and Ethiopian culture, and even more than Rosen working for what Rosen would later call the "organic development" of an Oriental country, Ilg was crucial for the success of the German mission. No matter how meticulous Rosen's preparations and circumspect his actions, it was in the end the culturally versed Ilg who was largely responsible for the success of the German mission, as both Rosen and his brother had no qualms in pointing out.

What made the mission and the German-Ethiopian negotiations successful was the transcendence beyond the technicalities of a friendship and trade agreement and the additional achievements were very much predicated on knowledge. Rosen engaged in diplomatic circles and tested out the grounds for additional German-Ethiopian collaboration, resulting in German participation in the banking and railway projects. Although knowing little about Ethiopia, Rosen arrived with Orientalist knowledge, which meant that he knew what the research agendas looked like in Germany and who would be a candidate for carrying out an excavation mission: his friend from Jerusalem, Littmann and not the scholar of Ge'ez Flemming, who was there alongside him. ${ }^{176}$ That the Kaiser would react with enthusiasm was to be expected, considering Wilhelm's wellknown affection for archaeology.

The scientific character of the diplomatic missions was striking. Rosen spent his spare time studying Somali songs and Flemming brought home a collection of seventy manuscripts and ten scrolls. Felix recorded songs, took photos, collected daily items and found a couple of new plants; one "in bushes in the grass steppe, half sticking in the ground", a herbaceous plant, he named Eulenburgia Mirabilis. Another one, a succulent evergreen tree, found in the garden of Menelik, gained the name Euphorbia Menelikii. Bringing along reproductions of old Ethiopian books, a scholar of Ge'ez, a doctor and a botanist with a penchant for trees and mechanical tinkering, the German mission was also willing to share its knowledge. The Germans believed in their own superiority contributing to the betterment and development of the country. As long as they stayed in political control, Menelik and his court members welcomed this involvement. Menelik's granting the right to excavate in Aksum after Rosen showed off his lancing skills at a day of equestrian festivities spoke to the momentum the negotiations took on. Rosen and Menelik found a basis of connection and the two acting in concert created new opportunities. ${ }^{177}$

176 Flemming, "Abessinische Handschriften in Berlin," 9.

177 Felix Rosen, Eulenburgia Mirabilis, 6 April 1905, 4011079, Herbarium Abessinicum, HMHNUW; Felix Rosen, Charakterpflanzen des abessinischen Hochlandes, 27/1. 
Even though Rosen was glad to leave Addis Ababa in mid-March, all of this studying, getting to know each other and eventually agreeing on a number of mutually beneficial goals was in large part also a matter of the length of time invested. While the Shah's trip to Europe lasted about the same time, his three day stay in Berlin was almost assured not to result in any tangible results. The Sondergesandtschaft, which must have cost anywhere upward from 200,000 Mark (without gifts and expenses for acquisitions), placed no such time constraints on Rosen and the Ethiopians. ${ }^{178}$ But this did not remedy the European limits placed on German power alone. Lacking political potential, Rosen revived the Prussian practice of placing scholars to the Orient and thought it best to learn and spread knowledge, while benefitting his caste of Orientalist scholars, the Auswärtiges Amt, chancellery, the "Roi de Prusse for whom I am working", himself and also the Ethiopians. ${ }^{179}$ Shortly before Rosen's departure from Ethiopia this mix of abilities and motives, largely congruent with Menelik's aspirations to develop his country and maintain independence, had the Negus Negesti write to Wilhelm: "Ihr werther Gesandter Dr Rosen war mir sehr sympathisch und sein Wissen hat mir sehr gefallen. Deswegen haben Wir ihn zu unserem Freunde gemacht.”180

\section{Imperial Rivalry and the Limits of Knowledge. Presenting Credentials to Sultan Mulai 'Abd al-'Aziz IV of Morocco in 1906}

Friedrich Rosen's journey from Tangier to Fez in the fall of 1906 to present his diplomatic credentials to the Moroccan Sultan Mulai 'Abd al-'Aziz IV was at first sight just that - a simple act of diplomatic protocol. Rosen had been appointed German envoy at Tangier in March 1905 and arrived in Morocco in November of that year. Although Fez was the Moroccan capital, the European legations were located at Tangier. While an international conference at Algeciras on the other side of the Strait of Gibraltar negotiated the terms under which Moroc-

178 Konrad von Studt and Otto von Mühlberg to Wilhelm II, 20 December 1904, A 19757, R 14914, PA AA; Bosch, Karawanen-Reisen, 142.

179 Friedrich Rosen to Nina Rosen, 15 March 1905, Briefe aus Abessinien, ASWPC.

180 "Your valued envoy Dr Rosen I found very sympathetic and I was pleased by his knowledge. Therefore, We have made him our friend.” Menelik II to Wilhelm II, 16 March 1905, A 10721, R 14915, PA AA; Menelik II, Ehrenstern von Äthiopien für Friedrich Rosen, 7 February 1905, ASWPC. 
co was to be reformed during the first months of 1906, Rosen stayed in Tangier without accreditation. By late February the Sultan expressed the wish for Rosen to come to Fez to be accredited. A year earlier the German envoy to Portugal, Christian von Tattenbach, had spent several months in Fez after the Kaiser's landing in Tangier to intervene against reforms advocated forcefully by French envoy Georges Saint-René Taillandier. Tattenbach's presence in Fez had aggravated German-French tensions. ${ }^{181}$ If Germany wanted to avoid accusations of conspiring with Morocco behind the backs of the other Europeans, Rosen was bound to wait with his accreditation trip to Fez for the completion of the Algeciras conference. Reminded again about the matter of accreditation by the Moroccan representative in Tangier after the conclusion of the conference in midApril 1906, Rosen agreed that this should happen promptly, but noted that the travelling season was coming to an end and that preparations for the caravan would take time. The German envoy would journey to Fez after the summer break in September. This would also allow enough time for the Moroccans to ratify the treaty worked out at Algeciras and Rosen would not cause a stir by his mere appearance before ratification. ${ }^{182}$

Originally set for the middle of September, the departure of Rosen and his entourage was then postponed to the end of the month, as the American envoy Samuel Gummere had in the meantime also made arrangements to present his credentials in Fez and was due to leave Tangier with a "vast caravan" on 15 September. The Chicago Daily Tribune reported that the situation had run hot the diplomatic telegraph-wires Tangier-Washington-Berlin-Tangier. Supposedly, Gummere had depleted Tangier's pack animal market, after renting "fifty mules, fifty asses, and fifty dromedaries". This started a rivalry of Gummere's and Rosen's vanities, the two men frantically running through little Tangier in search of donkeys, each envoy wanting to arrive in Fez first. The article observed it to be "probably the only case on record where arbitrage in jackasses nearly brought about international complications." ${ }^{183}$ None of this happened. Rosen was actually still on holidays in Berlin when the overlapping of missions was flagged by the US State Department. The situation was resolved amicably with the Germans postponing their journey by ten days to avoid a double diplomatic presence in Fez. Encapsulated in this harmless episode was, however, the

181 Mai, Marokko-Deutsche, 294; Clark, Schlafwandler, 211-15.

182 Friedrich Rosen to Bernhard von Bülow, 22 April 1906, Personalakten 12576, PA AA; Friedrich Rosen, Auswärtiges Amt. Marokkokrise, 271-72.

183 "Gummere Off to Fez Like Sheikh. Vast Caravan Accompanies the American Minister to Visit Sultan. Ironing Boards Big Item,” Chicago Daily Tribune, 26 September 1906, 3. 
jittery reporting of the international press about what did and did not happen in Morocco, often taking on a dynamics of its own in influencing diplomatic relations. ${ }^{184}$ In the aftermath of the Kaiser landing at Tangier and the high profile Algeciras conference, the world also took an interest in journeys of a diplomatic procedure, and rightly so. During his four-week stay in Fez, Rosen discussed the next steps of action with the Sultan and his court. Only bit by bit did the extent of agreements Rosen reached with the Moroccans transpire. Matters of culture and knowledge played a considerable role in the negotiations themselves and in the journey from Tangier to Fez and back. Equally important was the show the German envoy put on display for a larger audience in Morocco and globally.

In equally grand form as Gummere Rosen departed Tangier on 22 September to make the $270 \mathrm{~km}$ trip to the inland capital. His entourage consisted of a dozen German representatives. The majority were once again Gardes du Corps for decorative purposes, the retired German officer Georg Tschudi and a junior officer. Rosen was accompanied by Nina and his two sons Oscar and Georg on the journey. Rosen had not grown fond of Tangier, which he found dirty and a tourist trap for European cruises. Nina visiting the wives at the Sultan's court would be advantageous, but mostly Rosen wanted his sons to see Fez, renowned for its learning, architecture and culture. ${ }^{185}$ Taking his family along, however, also meant that they would not ride to Fez at speed. Rosen justified this leisurely pace in his memoirs as befitting to an Oriental grandee, who demonstrated refinement by a large caravan travelling slowly - a rule he sought to emulate. As Mangold has analysed, this “Oriental slowness” was in parts a retroactive idealisation of the journey when Rosen grappled with the upheavals of modernity in the Weimar era. The politics of his mission, however, were blinded out by Rosen in his memoirs. ${ }^{186}$ If compared to Gummere's journey and contextualised in the conflicts arising out of expropriation of the rural population in the Moroccan countryside due to Europeans buying up land, Rosen's orchestration of “Oriental slowness" at the time appreciates in significance. ${ }^{187}$

Rosen and his retinue took eleven days to reach Fez. Gummere with an equally large entourage took only five days. As the secretary of the US mission

184 Hermann Speck von Sternburg to AA, 1 September 1906, A 14992, R 15508, PA AA; Osterhammel, Verwandlung der Welt, 72, 678, 721; Clark, Schlafwandler, 303-11.

185 Friedrich Rosen, Auswärtiges Amt. Marokkokrise, 248-50.

186 Mangold, "Oriental Slowness”; Friedrich Rosen, Auswärtiges Amt. Marokkokrise, 272-312. 187 Edmund Burke III, "Mouvement sociaux et mouvement de resistance au Maroc: La grande Siba de la Chaouia (1903-1907)," Hespéris-Tamuda 17 (1976/1977): 149-63; Pascal R Venier, "French Imperialism and Pre-Colonial Rebellions in Eastern Morocco, 1903-1910," Journal of North African Studies 2, no. 2 (1997): 57-58. 
reported, it was still too hot to ride more than four to five hours a day along the caravan path of gravel and dried up river beds. But while heat should slow down these caravans, what sped them up was the perceived insecurity of the land. The Americans were "provided with a strong escort of Moroccan soldiers, but the Sultan did not trust the bravery of these to protect his distinguished visitors from the tribes of the desert." 188 Reports of "anarchy" in Morocco in the western press were the order of the day. Bandits robbed caravans, kidnapped Europeans, and ambushed Europeans out of anti-Christian sentiments. The Sultan lacked authority and, so went the reports, could not guarantee security in the countryside.

In this context on the first day of the US journey the New York Times reported that it was "a significant fact that Rais Uli, the bandit chief, sent presents" to the US delegation. ${ }^{189}$ Mulai Ahmed er-Raisuni, known as Raisuli in the West, was in 1906 the Moroccan governor of the countryside surrounding Tangier; he had previously made a career of kidnapping Westerners for ransom and as leverage for political gain with the Sultan. His ascendance to governor demonstrated his success. This had, however, made him a despised figure among many westerners for whom he came to embody the lawlessness of the country, which would only stop if a proper, that is European, police regiment was installed. For the vast majority of westerners based in Tangier, Raisuli was a bogeyman. He was feared, and fear of him was exploited for political gain.

Although the American mission had, like the German, appeared at first to be entirely ceremonial, it soon transpired that Gummere was in Fez to press the Sultan for indemnities for the (fake) American citizen Perdicaris, whom Raisuli had captured in 1904, and to guarantee the future security of US citizens. To underline the point, three American ships appeared before Moroccan shores. ${ }^{190}$ Given the supposed anarchy of the land and the animosity towards Raisuli, the American delegation had thus no intention of spending too much time on the journey.

Rosen's intentions were different. Still branded as a bandit and not recognised by any other European legation, Rosen had entered backchannel relations with Raisuli. The governor provided security to Rosen whenever he left Tangier.

188 "Back from Morocco; Met the Sultan in Fez. Secretary Iselin Tells of His Trip with Minister Gummere,” New York Times, 19 November 1906.

189 "Gummere Starts for Fez. It’s the First Visit of any American Minister-Presents from Rais Uli,” New York Times, 16 September 1906.

190 "Our Demands on Morocco. Importance of Gummere's Mission to Fez Being Underestimated,” New York Times, 18 September 1906; "Gummere Mission Fails. American Gets No Satisfaction from Morocco, It Is Reported,” New York Times, 30 November 1906; Edmund Dene Morel, Morocco in Diplomacy (London: Smith, Elder \& Co, 1912), 114. 


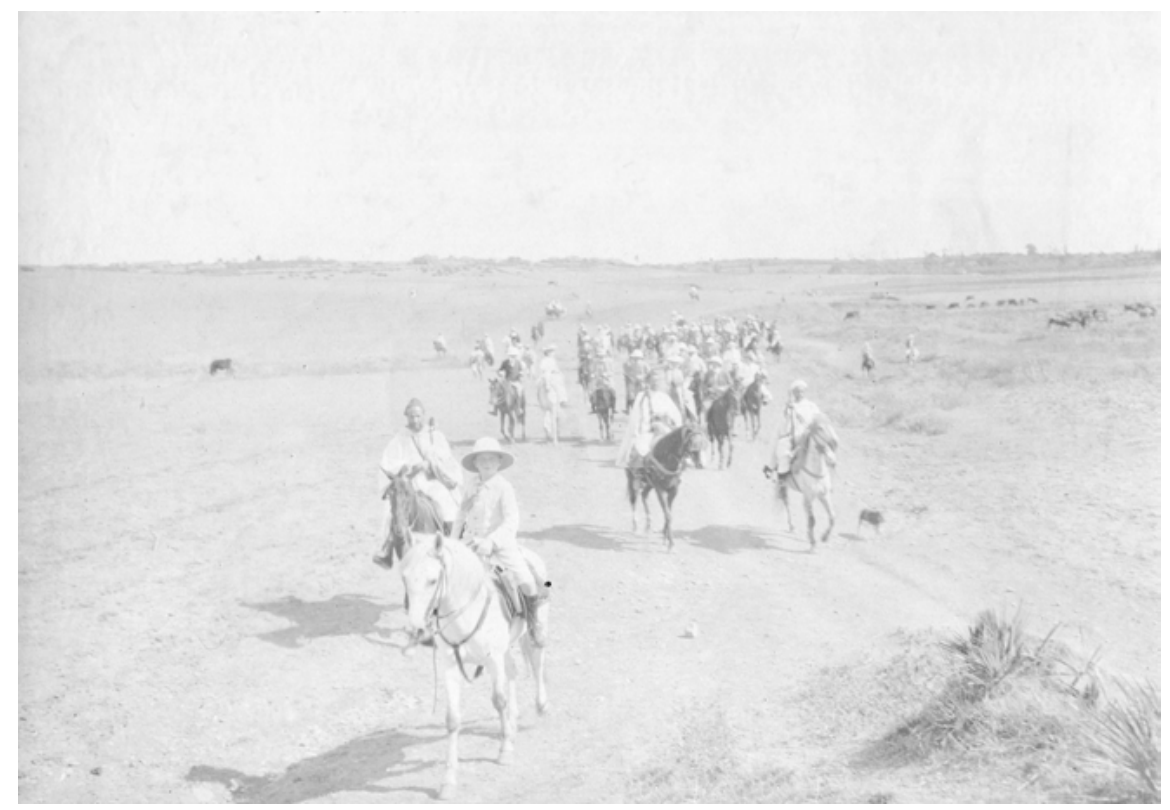

Fig. 4.3. "Oscar leads the caravan." Journey of the German delegation from Tangier to Fez, September 1906.

Berlin knew this and Rosen was backed from up high. Wilhelm II fancied Raisuli to be a Moroccan Götz von Berlichingen, a Franconian knight who gained fame for his battles and poetry in the German Peasants' War in the sixteenth century and popularised in the late eighteenth century by Johann Wolfgang von Goethe as a free-spirited national figure, transcending the feudal system, fighting for the poor and sticking it to the man. ${ }^{191}$ As had been the case with the American mission, on their way out of Tangier gifts from Raisuli awaited the Germans. To demonstrate that the countryside was safe from banditry and secured by its governor, Rosen organised a dinner for the European diplomatic corps of Tangier in the countryside on the first evening of the journey to Fez. On the way to Fez and back, Rosen continued to celebrate this show of peace in the land, accepting the invitation to dine with locals every $25 \mathrm{~km}$ or so.

191 Ernst Langwerth von Simmern to Bernhard von Bülow, 17 November 1906, A19215, R 15493, PA AA; Friedrich Rosen, 1926, Hinterlassene Manuskripte I, 6 NL Müller-Werth, PA AA, 93; Johann Wolfgang von Goethe, Götz von Berlichingen mit der eisernen Hand (London: D. Rutt, 1840), 91-92. 
An incidence of violence outside Tangier in October thwarted Rosen's public relations work. Seen gravely in European quarters it precipitated the movement of Spanish and French ships to the Moroccan coast and a false rumour made the rounds among the scared Europeans in Tangier that the Germans and the Americans were stuck in Fez because of the insecurity in the countryside. The rumour was false. The duration of the stay of the Germans and Americans in the capital was due to ongoing political negotiations. ${ }^{192}$ When Rosen arrived back in Tangier he was astounded by the commotion in the harbour city about an insecurity in the land which he had not felt. Rosen was not alone in observing that reports of violence and disturbances were often unconfirmed, tended to be exaggerated and took on a life of their own, after they travelled from wherever in the large country they took place via Tangier into the Western press. There were instances of violence to be sure, but German consular reports from Fez, Casablanca and Marrakesh found the supposed Moroccan "anarchy" to be a myth. ${ }^{193}$ This dissenting reading was also found in the local English press and was supported by the liberal British "trouble maker" Edmund Dene Morel and French socialists. ${ }^{194}$ An article in Al-Moghreb Al-Aksa put the blame for the disturbances squarely at the feet of the impositions of Algeciras. Nine-tenths of the Moroccan population were opposed to a Franco-Spanish police force, the Sultan's submission to Algeciras constituting

the last straw to break the back of the Makhzen's [Sultan's court] authority. Hence the wholesale pillage of the trade caravans, the paralysis of commerce, and the deadly hostility to every kind of imported reform... To many of us sojourners in the Land of Sunset it appears, indeed, that the indiscreet vapourings of the "penetration" press are responsible for half the troubles now afflicting all foreign residents. ${ }^{195}$

As Rosen reported to Berlin, the consequence of Morocco becoming in the European imaginary one big chaos was that unrelated events in the country were put into a non-existent context: "Nothing is more contagious than fear and

192 Ministère des Affaires Étrangères, Documents diplomatiques. Affaires du Maroc. 1906-1907 (Paris: Imprimerie Nationale, 1907), 85; "Anarchy in Morocco. France and Spain to Send War Ships to Protect Their Subjects,” Washington Post, 27 October 1906, 5; New York Times, 26 October 1906.

193 Ernst Langwerth von Simmern to Bernhard von Bülow, 13 July 1906, A 12779, R 15493, PA AA; Ernst Langwerth von Simmern to Bernhard von Bülow, 19 August 1906, A 14673, R 15493, PA AA; Friedrich Rosen to Bernhard von Bülow, 28 June 1906, A 11780, R 15493, PA AA; Friedrich Rosen to Bernhard von Bülow, 11 December 1906, A 21073, R 15493, PA AA; Friedrich Rosen to Bernhard von Bülow, 16 October 1906, A 17897, R 15493, PA AA.

194 Morel, Morocco in Diplomacy, 101-2, 114; Taylor, Trouble Makers, 96.

195 "Disturbed Morocco," Al-Moghreb Al-Aksa, 10 November 1906. 
thus even usually calm thinking people had persuaded themselves that we were at the eve of horrific events."

In another instance the German envoy intercepted a telegram from France that ordered a press story intended to scandalise Raisuli. Rosen speculated that parts of the press had been bought by colonial circles in France wanting to orchestrate or portray insecurities in the country to open up financial and political resources in the metropole to speed up the introduction of the police force in Morocco. ${ }^{196}$ An article in Le Matin titled "Call to arms. Morocco preaches holy war” reinforced such assumptions among the German diplomats, who thought the holy war fright exaggerated. Rosen contrasted this portrayal with reports that the people in Morocco were very friendly and welcoming, particularly to those who spoke Arabic and were open to them. ${ }^{197}$ It was not genuine understanding that mattered, but the politeness and fearlessness the Germans expressed reinforced a friendly German image that had prevailed since the Kaiser's landing in Tangier the year before. This positive Moroccan disposition allowed Rosen to foster relations in the countryside, learn a bit about the land and its people, and speak of peace in the countryside when he returned to diplomatic Tangier: for him and his travelling party it had been peaceful. But the Europeans in the city thought he was pulling their leg. In fact, instead of having demonstrated to his diplomatic cohort security outside the city walls, Rosen had given reason to believe that he was conspiring with Raisuli and by the end of the year saw himself forced to "contradict rumours that Raisuli... hoisted the German flag" at his castle in Zinnath. ${ }^{198}$ Rather than dispelling European fears, or breaking the news cycle, Rosen's demonstrations of fearlessness intensified the discourse by associating the quarrelsome Germans with the Moroccans.

The German delegation arrived in Fez on 2 October. With their Gardes du Corps and officers wearing full costume and heavy silver eagle helmets, they left quite an impression with their hosts. While the US delegation had like the German delegation been received outside the city gates by several thousand

196 Friedrich Rosen to Bernhard von Bülow, 27 November 1906, A 20342, R 15493, PA AA.

197 Friedrich Rosen to Bernhard von Bülow, 27 November 1906, A 20342, R 15493, PA AA; Friedrich Rosen to AA, 1 March 1907, A 3439, R 15493, PA AA; René Moulin, “Appel aux armes. Le Maroc prêche la guerre sainte," Le Matin, 21 October 1906; "Les Marocains veulent attaque la France," Le Matin, 15 October 1906; “Le Maroc et nous," Le Temps, 14 October 1906; Friedrich Rosen, Auswärtiges Amt. Marokkokrise, 251.

198 Friedrich Rosen to Bernhard von Bülow, 13 November 1906, A 19598, R 15508, PA AA; “Morocco. Rumour Contradicted," South China Morning Post, 2 January 1907, 7; "Parteien und Parteiführer in Marokko," Münchener Allgemeine Zeitung, 2 October 1906; Morel, Morocco in Diplomacy, 115. 
men, only the German delegation was on the day of the official reception accorded guards of honour all the way from the German residence to the royal palace. The court had prompted the city's notables to organise a particularly festive reception for the Germans, and the press picked up on the difference. ${ }^{199}$ At the reception itself gifts were presented, most of which were rather "usual", as Rosen and the press reported. ${ }^{200}$ There were a couple of exceptions. The German delegation had brought a miniature wireless telegraph, which Rosen had wanted Tschudi to present to the Sultan 'Abd al-'Aziz, known to be an admirer of all things European and technological. The Sultan suggested that this would break the ceremony and Tschudi should return on the next day with the telegraph. ${ }^{201}$ Another set of gifts were a number of books, many of which were German prints of Arabic works, and Rosen was able to impress the "astonished" Sultan with the news that there were some twenty universities in Germany where Arabic was taught. On top of the stack was the German production of the Divan of Selim I, a sixteenth century Ottoman ruler who had written poetry in Persian. As Kreiser has shown, the volume had been re-produced by the Iranists Paul Horn and Oskar Mann with the support of Rosen in the Auswärtiges Amt for the Ottoman Sultan Abdülhamid in the years before. The original dedication to the Ottoman Sultan printed on one of the first pages had been glued together with the previous page. Although in Persian, the Moroccan Sultan 'Abd al-'Aziz was "apparently much pleased" with the gift and asked Rosen to read from the first page. ${ }^{202}$

Rosen's main source of information about Fez had been the long-time German consul Philipp Vassel at Fez. Through Vassel, who was not in Fez at the time, Rosen had learned that the Tassi brothers - one the finance minister, another a banker, a third the lord protector of Fez and a confidant of the Sultan would be most important for gaining influence at the Sultan's court. Rosen bought them off by offering the banker to be placed on the board of an international banking consortium in exchange for their support at court. ${ }^{203}$ With the

199 "Rosen Enters Fez in Great Pomp,” New York Times, 9 October 1906; “The German Mission to Fez," Manchester Guardian, 12 October 1906, 6; Friedrich Rosen to Bernhard von Bülow, 13 November 1906, A 19598, R 15508, PA AA; Friedrich Rosen, Auswärtiges Amt. Marokkokrise, 281. 200 "Many Gifts from Kaiser. German Mission Presents Them to the Sultan of Morocco," New York Times, 12 October 1906.

201 Friedrich Rosen, Auswärtiges Amt. Marokkokrise, 287.

202 Friedrich Rosen to Bernhard von Bülow, 6 October 1906, A 17339, R 15508, PA AA; Kreiser, "Divan for the Sultan," 283.

203 Klaus Vassel, Berlinische und marokkanische Erlebnisse meines Vaters 1873-1911 (Aachen: Wilhelm Metz, 1975), 94; Friedrich Rosen, Auswärtiges Amt. Marokkokrise, 286. 
Sultan sufficiently assuaged as to German intentions and with the Tassi brothers on the German side as well, Rosen turned to a private audience with the foreign minister Si 'Abd el Krim Ben Sliman, whom Rosen had known to be aligned with French interests for reasons of expediency. After finding only a lukewarm welcome with Ben Sliman, what broke the ice was, in Rosen's words, his speaking in Arabic and their conversations quickly drifting to matters of history, culture, sciences and architecture. ${ }^{204}$ According to Rosen's memoirs, they also talked business, but the diplomatic reports do not indicate that any of the deals were done in the presence of Ben Sliman. On the contrary, the foreign minister appears to have been adequately distanced from the deals so that he could impress "very categorically" upon the French representative Eugène Regnault several months later that all deals in Fez that autumn had been done between Rosen and the Sultan alone and without his knowledge. ${ }^{205}$ It is not clear if Rosen managed to mollify the foreign minister and thus prevented immediate leaks to the French or if Ben Sliman simply calculated that amid the state of things the risk of alienating his French interlocutors was worth the gamble on the Germans bringing some relief to the heavily embattled court.

After having taken a beating together at Algeciras, the show the Germans had put on display in the procession to Fez and Rosen's interest in traditions and culture of the venerable centre of the formerly mighty Sharifian empire confirmed the commitment expected of the Germans. With Algeciras ratified, but the police forces not yet on Moroccan grounds, a close collaboration with Germany was the last chance to preserve some sort of control. It is doubtful that only the niceties of expressing interest in Moroccan culture and history created an opening for collaboration. Rosen was a last chance and the Moroccans had no other options that was all. In one regard Rosen's knowledge did prove advantageous though. Talking alone with the Sultan in Arabic without the help of a Moroccan interpreter ensured confidentiality on the most sensitive matters. ${ }^{206}$

With the ungrateful task of having to stand behind Algeciras and the impending French police mission, Rosen negotiated a few concrete matters of more or less advantage to both sides. The two sides agreed on a German-Moroccan modus operandi regarding the implementation of the Algeciras agreement, which included next to the police reforms a bundle of legal, financial and eco-

204 Friedrich Rosen to Bernhard von Bülow, 16 November 1906, A 19601, R 15508, PA AA; Friedrich Rosen, Auswärtiges Amt. Marokkokrise, 286; Karl Emil Schabinger von Schowingen, Weltgeschichtlicher Mosaiksplitter. Erlebnisse und Erinnerungen eines kaiserlichen Dragomans, Karl Friedrich Schabinger von Schowingen (Baden-Baden: Selbstverlag, 1967), 34-36.

205 Ministère des Affaires Étrangères, Affaires du Maroc 1906-1907, 176.

206 Friedrich Rosen, Auswärtiges Amt. Marokkokrise, 287. 
nomic reforms to be partially worked out by the Moroccan government and partially by European diplomats in Tangier. The Moroccans would consult the German envoy on all moves made by the French. Rosen noted: "Dies sichert den Marokkanern eine technische Hülfe, deren sie unbedingt bedürfen, uns jedoch eine vermehrte Einwirkung auf die Gestaltung der Bedingungen, mit welchen wir für die Zukunft zu rechnen haben werden.” The arrangement also included the replacement of former Krupp liaison and German engineer Walter Rothenburg in Moroccan service. The retired officer Tschudi would take his place and become the new public works' consultant of the Sultan. Tschudi would be in a position to prevent France from gaining concessions and to ensure sympathetic consideration of German requests. ${ }^{207}$ Another German officer was to take on the training of the Moroccan cavalry. Furthermore, the extension of the harbour of Tangier by a German syndicate was agreed upon "in binding and also externally incontestable form”. 'Abd al-'Aziz also agreed to harbour constructions south of Tangier at Larash, to include German bankers on the board of Morocco's state bank, and to have Morocco's only gunboat, the "Turki”, revamped in Germany. Its German commander Leonhard Karow had approached Rosen on the matter. In the future boats would be purchased from Krupp, the Sultan promised. ${ }^{208}$ In other good news for German enterprise, the businessman Reinhard Mannesmann received preferential rights over iron mining in the country, which would be formalised after a mining law had come into effect.

The mining matter had been driven by Mannesmann, a German industrialist, who had come to Morocco on honeymoon and toured the country along its shores on the "Turki". The appearance of Mannesmann had quickly aroused French suspicions. ${ }^{209}$ Before his summer holiday in Germany Rosen had tried to keep the industrialist away from German politics and told him to approach the Sultan on his own, with the incentive of including the Moroccans in the profits. In Rosen's absence Mühlberg cautioned the chargé d'affaires Ernst Langwerth von Simmern that the situation was difficult, as open collaboration with

207 "This secures a technical help for the Moroccans, which they absolutely need, but for us it secures an increased influence on the formation of the conditions with which we have to contend for the future.” Friedrich Rosen to AA, 20 October 1906, A 17689, R 15508, PA AA; Friedrich Rosen to Bernhard von Bülow, 13 November 1906, A 19598, R 15508, PA AA; Jonathan G. Katz, Murder in Marrakesh. Émile Mauchamp and the French Colonial Adventure (Bloomington: Indiana University Press, 2006), 171.

208 Leonhard Karow, Neun Jahre in marokkanischen Diensten (Berlin: Wilhelm Wicher, 1909), 217; Gunther Mai, Die Marokko-Deutschen 1873-1918. Kurzbiographien (Göttingen: Vandenhoeck \& Ruprecht, 2014), 92.

209 "Germans in Morocco," Manchester Guardian, 17 April 1906, 7. 
Mannesmann could be read as disloyal in the spirit of the Algeciras agreement. At the same time, however, the German government wanted to support its industrialists. Could the Sultan not be motivated to work with Mannesmann without official German participation? But Mannesmann, who had in the meantime relocated to Fez, pressured the German government, as he had gotten wind that French industrialists were also working on attaining mining rights. ${ }^{210}$ After his return from Berlin, Rosen brought Mannesmann into the loop, first - unofficially - pressing for his preferential rights with the Sultan, and then including Mannesmann and other German business representatives in the drafting of a mining law for the Moroccan court to adopt, thus enabling Mannesmann to translate his preferential rights into real concessions. ${ }^{211}$ At Fez, Rosen met with Mannesmann and worked on the industrialist's behalf, although he disliked his impertinence. Later they became embroiled in a protracted conflict over the intricacies of concession law, which would pit the Alldeutsche colonialist circles against the Auswärtiges Amt. ${ }^{212}$

On the results of his discussions at the Sultan's court, Rosen noted in a telegram to Berlin, that Deutsche Bank, Krupp and the German-Moroccan syndicate of business should be pleased with these achievements. The marginalia indicate that the Auswärtiges Amt was more skeptical and thought that most of these achievements were momentary and not secured. ${ }^{213}$ With the exception of the posting of Tschudi and the cavalry officer to the Sultan's court, the agreements were not politically insignificant but driven by the economic interests of Germans in Morocco or the mission of Auswärtiges Amt to pander to large business interests in Germany. There were bits and pieces in these projects for the Moroccan government and state as well, but essentially these were piecemeal German projects foisted on Morocco. The Sultan accepted the German proposals, as Germany was his only chance for delaying French encroachments. Rosen wrote to Bülow that "the Sultan unashamedly expressed his gratitude for his majesty

210 Friedrich Rosen to Bernhard von Bülow, 4 May 1906, A 63, R 15493, PA AA; Otto von Mühlberg to Ernst Langwerth von Simmern, 7 July 1906, A 9125, R 16039, PA AA; Ernst Langwerth von Simmern to AA, 13 July 1906, A 9125, R 16039, PA AA; Friedrich Rosen to Ernst Landwerth von Simmern, 14 July 1906, A 12293, R 16039, PA AA; Friedrich Rosen to Bernhard von Bülow, 20 September 1906, A 16312, R 16039, PA AA.

211 Friedrich Rosen to AA, 8 November 1906, A 16312, R 16039, PA AA; Friedrich Rosen to Bernhard von Bülow, 5 March 1907, A 3697, R 16039, PA AA.

212 Friedrich Rosen, Auswärtiges Amt. Marokkokrise, 294297; Vassel, Berlinische und marokkanische Erlebnisse, 95-97; Heinrich von Eckardt to Friedrich Rosen, 24 April 1909, A 1036, 1906-10, ASWPC; Heinrich von Eckardt to Friedrich Rosen, 17 April 1909, A 1036, 1906-10, ASWPC; Hermann von Rotenhan to Friedrich Rosen, 24 April 1909, 1906-10, ASWPC.

213 Friedrich Rosen to AA, 26 October 1906, A 16312, R 16039, PA AA. 
the Kaiser and King, in whom he beholds his rescuer". ${ }^{214}$ This gratitude was also expressed through a gift to Rosen of a "pageant saddle in green velvet and brocade, as green is the holy colour of Islam and is generally not bestowed to Christians”. ${ }^{215}$ Overall, strengthening of German interests and weakening French control amounted to a reversal of the structures of influence at the court of Fez. Rosen had landed a small coup, and the Kaiser was pleased. ${ }^{216}$

In ostensible contradiction to these positive results of his discussions, Rosen sent a longer report, that Wilhlem equally praised: "All my foreign ministers should report like this." In this report, Rosen outlined the larger picture of the situation at Fez and in Morocco. In a cultural-historical tour de force Rosen posited that Fez rivalled Damascus for its splendour, a centre of learning, culture and sciences. The ossification of Moroccan culture in Fez, however, had caused a pull back of the state from the surrounding countryside into the city walls. The stagnation in the countryside led to decay, which was only sped up by European encroachments. The Sultan had been and continued to be a modernist, but having ascended the throne at the age of sixteen, he had been abused by the people around him and the Europeans, who took advantage of his inexperience. The Sultan had come under attack from the more pious quarters of the country for his penchant for European gadgets, which was largely intensified by his inability to quell unrest and preserve the territorial integrity of the country against French and Spanish machinations. Rosen had tried to impress upon the Sultan that if Algeciras was adhered to with German help the situation could still be turned around, but he found the Sultan largely apathetic, often not wanting to know details or being kept in the dark by the people around him. ${ }^{217}$ Rosen had hardly believed that Morocco could be preserved as a sovereign state before he had travelled to Fez, but by the end of his stay he found that there was no one in the city who would be able to improve the situation. Opening his report with the words "who is so lucky to have seen Fez, the singular capital of western Islam among the great cities of the Muslim countries", the report was intended for Bülow and the leadership in Berlin to know what German foreign policy could expect from crumbling Morocco and Islamic countries in the future. Wilhelm commented "now we have some clarity where we stand and with whom we are dealing."218

214 Friedrich Rosen to Bernhard von Bülow, 13 November 1906, A 19598, R 15508, PA AA. 215 Friedrich Rosen to Bernhard von Bülow, 13 November 1906, A 19598, R 15508, PA AA; Theilhaber, "Bestände Rosen Detmold".

216 Friedrich Rosen to Bernhard von Bülow, 13 November 1906, A 19598, R 15508, PA AA.

217 Friedrich Rosen to Bernhard von Bülow, 16 November 1906, A 19601, R 15508, PA AA; Morel, Morocco in Diplomacy, 41.

218 Friedrich Rosen to Bernhard von Bülow, 16 November 1906, A 19601, R 15508, PA AA. 
In the direct aftermath of the Fez trip Rosen's position strengthened at the Sultan's court and economic prospects looked promising enough to start working on the mining law with Mannesmann. But only a couple of weeks after his return to Tangier on 6 November Rosen wrote to Berlin that he was in an inferior position against the French representative Regnault at Tangier's diplomatic council, noting that with the introduction of the inevitable Franco-Spanish police force, all other considerations and German actions in the country would become obsolete. ${ }^{219}$ As the Raisuli situation at Tangier began to boil over and the arrival of French and Spanish warships at Tangier increased the hand of Regnault, the French representative pressed for punitive action against the Sultan's governor. Playing for time, Rosen intervened by insisting with the diplomatic corps in Tangier that such an action overstepped the limitations of Algeciras, and suggested that it was only legitimised in the $10 \mathrm{~km}$ zone around Tangier in which the treaty allowed European land purchases. The council agreed. Through his channels at the court in Fez, "the wicked Teuton" Rosen, as he became known by then in the international press, moved the Sultan to use his latest French loan to assemble an army of 1,500 men and move on Raisuli's mountain fort at Zinnath, thus implementing the demands of the diplomats in Tangier and leading to a pull back of the Franco-Spanish fleet. ${ }^{220}$ This maintained Moroccan sovereignty for a stretch longer, and calmed press attention for the moment, but with that the Sultan had exhausted his finances and the force disintegrated outside of Tangier amid outstanding payments.

Rosen had failed with his ostentatious "Oriental slow travelling” to calm European nerves in Tangier or swing public opinion beyond. He could also not bring the French dominated diplomatic council to recognise Raisuli as governor, even less so with a Franco-Spanish fleet on the shores. Instead Rosen sacrificed in Raisuli a partner to preserve the sovereign Sultan and the influence Germany still had with him. ${ }^{221}$ With the forlornness of Germany's position in Morocco becoming clear, Rosen wrote to Bülow that he had until this point pursued a strat-

219 Friedrich Rosen to Bernhard von Bülow, 6 November 1906, A19216, R 15508, PA AA; Friedrich Rosen to Bernhard von Bülow, 27 November 1906, A 20342, R 15493, PA AA.

220 Friedrich Rosen to AA, 19 December 1906, A 21103, R 15493, PA AA; Friedrich Rosen to AA, 20 November 1906, A 19952, R 15875, PA AA; "The Fleets at Tangier. Sultan Intends to Greet French Admiral?” Manchester Guardian, 6 December 1906, 7; Friedrich Rosen to AA, 14 January 1907, A 702, R 15493, PA AA; Ministère des Affaires Étrangères, Affaires du Maroc 1906 - 1907, 124; Albrecht Mendelssohn Bartholdy and Friedrich Thimme, eds., Die Auswärtige Politik des Deutschen Reiches. 1871-1914 (Berlin: Deutsche Verlagsgesellschaft für Politik und Geschichte, 1928), 736; Morel, Morocco in Diplomacy, 41, 115.

221 Morel, Morocco in Diplomacy, 43; Ernst Langwerth von Simmern to Bernhard von Bülow, 17 November 1906, A19215, R 15493, PA AA; Karow, In marokkanischen Diensten, 232. 
egy of following Regnault in all things agreed upon at Algeciras, but had resisted on actions against Morocco beyond this point. This had worked so far without scandal, but would not last long, as Germany would continuously be the only voice of opposition in the council: "Der deutsche Widerstand würde mit der Zeit seitens der Franzosen zu unbequem empfunden werden, als dass sie nicht auf Mittel sinnen sollten, mit Hülfe der auf ihrer Seite stehenden Mächte ihre Pläne zu verwirklichen und uns zur schliesslichen Zustimmung zu bewegen.” Germany would lose all influence in the country to France eventually. Rosen suggested that Germany should "obtain an equivalent from France” while it still had influence. 222 There was no response from Berlin, which Mai analyses as follows: "The old dilemma manifested: Germany had too little interest. The government did not want more but to occupy and distract France [in Morocco]."223 Similarly, the knowledge that had been generated by Rosen's journey to Fez provoked little effect on policymaking. The Kaiser, not particularly interested in Morocco anyhow, saw himself validated in Rosen's report. The Auswärtiges Amt, with state secretary Oswald von Richthofen just having died of karoshi and Bülow embroiled in the Eulenberg-Harden affair, ignored what Rosen had learned about Moroccan affairs and how this would affect Germany's position in European powerpolitics. $^{224}$

Shortly later, the French press reported that the German officer Tschudi would replace the former chief engineer at the Sultan's court and would take along another German officer to Fez, and speculated if they would equip the sultan with Krupp weapons. Confronted by Regnault, Rosen did not convincingly dispel his suspicions, and in the first months of 1907 Rosen's visit in Fez became associated in the international press with German intrigues that drove the Moroccan resistance. ${ }^{225}$ As the Moroccans continued to consult Rosen on how to react to French demands and suggestions, Rosen became, as he wrote, an executor of French wishes with the Moroccans. By the spring of 1907, Rosen asked the sultan to no longer consult him, and Vassel in Fez reported that he lost access to the goings-on at the sultan's court, that the Tassi brothers were removed from

222 "The German resistance would with the time be conceived as too bothersome for the French for them not to devise the means with the help of the powers on their side to realise their plans and finally drive us acquiesce.” Friedrich Rosen to Bernhard von Bülow, 21 December 1906, A 215914, R 15508, PA AA.

223 Mai, Marokko-Deutsche, 320.

224 As Winzen notes, Bülow had in fact been pursuing colonial interests in Morocco. Clark, Schlafwandler, 264-265; Winzen, Bülow, 319-31; Winzen, Ende der Kaiserherrlichkeit, 29-38. 225 "Les Allemands au Maroc," Le Temps, 8 February 1907; Ministère des Affaires Étrangères, Affaires du Maroc 1906-1907, 159, 165-66; Mai, Marokko-Deutsche, 319. 
power and that the French-leaning Ben Sliman was again firmly in charge. ${ }^{226}$ Then, in March 1907 the French doctor and agent Mauchamp was murdered in Marrakesh. The death of the doctor was instrumentalised by the French and international press to construct a story of civilised supremacy over backward Morocco. Rosen stayed away from the commemorative ceremonies and the press allotted blame to him for the inconsiderateness of his not siding more pronouncedly with the French in a situation when Oriental, Islamic fanaticism was supposed to have killed an enlightened figure of European civilisation. ${ }^{227}$

In international diplomatic circles Rosen was scolded for his lack of "tact" in the matter. Holstein and Bülow used Rosen as a scapegoat, agreeing with British circles that he was a "careerist" and sought the limelight of the press to make a name for himself. When Rosen left for summer holidays in 1907, the press thought that he would not return. ${ }^{228}$ At the time a Berlin newspaper summed up Rosen's visit to Fez with a dialogue of two ordinary Berliners:

Schultze. Kennste Rosen?

Müller. Na, wo werd' ick denn keene Rosen kennen.

Schultze. Ick meeen nich de Blume, sondern den Jesandten in Marokko.

Müller. Ach so! Kenne ick ooch. Er war bein Sultan und hat ihm 'nen lenkbaren Luftballon jeschenkt.

226 Friedrich Rosen to AA, 14 April 1907, A 6028, R 15493, PA AA; Friedrich Rosen to AA, 15 March 1907, A 4798, R 15493, PA AA.

227 Vassel blamed Rosen for Mauchamp's death: after Tschudi interested the sultan in telegraphy, French groups got wind of this and moved fast in setting up a telegraph system on their own - illegally. Rosen had Vassel tell the sultan to intervene against the illegal French system. The sultan ordered his police to stop such constructions. Mauchamp had put up a weather antenna on his house, which the police mistook for a telegraphy mast. Mauchamp resisted his arrest and died in the police action. Chronologically, the story does not add up as the Germans had lost their influence in Fez at that point. Walter B. Harris, "France and Germany in Morocco. Charges Against the German Minister," Times, 16 July 1907; "Morocco Expects Aid from Germany,” New York Times, 28 April 1907; Friedrich Rosen to Bernhard von Bülow, 23 April 1907, A 6907, R 15493, PA AA; Ellen Amster, "The Many Deaths of Dr. Emile Mauchamp: Medicine, Technology, and Popular Politics in Pre-Protectorate Morocco, 1877-1912," International Journal of Middle East Studies 36, no. 3 (August 2004): 409; Grasset, A travers la Chaouïa avec le corps de débarquement de Casablanca (1907-1908) (Paris: Librairie Hachette, 1911), 1-6; Vassel, Berlinische und marokkanische Erlebnisse, 98-99.

228 Maximilian Harden and Holstein agreed that Rosen was the "Huckebein unserer Marokkopolitik" - the jinxed and evil crow of Wilhelm Busch's children's story. Driven by "private ambition", Rosen shared with the Kaiser the "specialty of running the state-wagon into the ditch". Rich, Fisher, and Frauendienst, Holstein 1897-1909; Edward Grey to Francis Bertie, 22 August 1907, 53/33 II (D15), R/15/1/507, BL IOR; Harris, “Charges Against the German Minister”; Urlaubsnotiz, 29 May 1907, 6946, Personalakten 12576, PA AA. 
Schultze. Stimmt. Det scheint mir ein Symbol zu sin. Wat der Luftballon is, der hat ville Ähnlichkeiten mit'n Sultan von Marokko.

Müller. Er bläht sich uf un tut sich dicke.

Schultze. Un wird doch an die Strippe jehalten.

Müller. Un wenn er seine Arbeet jetan hat, wird er ausjepumpt und injepackt.

Schultze. Ja, det Pumpen is bei beiden die Hauptsache. ${ }^{229}$

Rosen did return, staying on as envoy for another three years, scheming on behalf of the Auswärtiges Amt and German business interests or on his own initiative against the French, and with changing Moroccan constellations. With his health impaired and after the death of his son Oscar in September 1907, Rosen drifted into melancholia, writing to his friend Andreas that his life had become "dedicated to a politics, that appears to aim at failure". ${ }^{230}$ Shortly before Rosen was posted to Bucharest in 1910, the Krupp representative in Morocco noted that the "resigned Rosen lets everything happen." ${ }^{31}$

The accreditation journey to Fez, his negotiations there, and the aftermath in the winter of 1906/7 showed that Rosen was not in his element. He worked methodically for German interests in Morocco, but he had an open flank that would come to hurt him, and Moroccan and German interests in the process. Rosen knew very little about Morocco or the Maghreb more generally, nor had he developed any major interest in the country, its culture, history or politics previously. However, by virtue of Orient being Orient in Germany he was expected to perform there politically, with his supposedly superior knowledge opening doors. From Berlin he received little further support. In marked contrast to a number of previous postings, he was initially well-liked in the German community as a "loyal council and helper". ${ }^{232}$ Rosen was tied into numerous micro-interests

229 “Schultze. You know Rosen? Müller. Why, how can I not know roses. Schultze. I don't mean the flower, but the envoy in Morocco. Müller. Oh! Know him as well. He was with the Sultan and gave him a steerable balloon. Schultze. Right. Seems to be a symbol. What the balloon is, it has many similarities with the Sultan of Morocco. Müller. He bloats himself up and brags about. Schultze. And is still kept on a tight rope. Müller. And when he has done his work he is pumped out and stacked away. Schultze. Yes, pumping is with both the most important.” Newspaper Clipping, 1906-1907, ASWPC.

230 Friedrich Rosen to Bernhard von Bülow, 6 May 1907, 1248, Personalakten 12576, PA AA; Heinrich von Tschirschky to Wilhelm II, 6 September 1907, 2448, Personalakten 12576, PA AA; Friedrich Rosen to F. C. Andreas, 25 May 1909, 3611 Cod. Ms. F. C. Andreas, SUBG.

231 Müller-Werth, Ein staatsmännisch denkender Diplomat, 27.

232 On the other side of the conflict over the Mannesmann affair in 1909 and tinged by antiSemitic sentiments, Vassel developed a hatred for Rosen, calling him "an aesthete and phraseur, who saw himself as a rose blossom of world history". Schabinger recorded further conflicts between Rosen and the Morocco-Germans. Karow, In marokkanischen Diensten, 126; Schabinger 
in Morocco, with even more interests to be served in Germany, and he came to rely vastly on the German community for information and input. Visibly on the other side of the aisle from England, Rosen could not approach his usual goto point for orientation or supplementary information. This was a complete change from his previous ways of international cooperation. As any expression of solidarity with the criminal, uncivilised, fanatic, Muslim, Berber, Moors was frowned upon and watched with eagle eyes, establishing working relationships or trustworthy channels of information with his Moroccan counterparts was difficult. Rosen did so still, even if he saw the country and the Sharifian empire nearing its end.

Some of his overtures were schemes against the French - what he called "rear-guard battles". In other instances, Rosen expressed sympathies for the Moroccans that went beyond simple intrigue against France. In advocating for the recognition of Raisuli, he argued that the man was like Sultan 'Abd al-'Aziz a Sharif, a descendant of Idris I (eighth century) and by extension of the prophet Mohammed and thus could claim religious legitimacy for his governance. ${ }^{233}$ When 'Abd al-'Aziz started losing power and the initially French-supported brother of 'Abd al-'Aziz Mulay Hafid started occupying vast territories of the country, Rosen suggested that the European refusal to recognise Mulay Hafid's sovereignty was in the Moroccan context invalid, as he was already de jure Sultan according to Moroccan law: "formal recognition through foreign powers would be a novum. Customary notification has taken place." ${ }^{234}$ In working out the legal codifications coming out of Algeciras, Rosen pressed on the diplomatic council to not merely impose European legal concepts but to be mindful of "Muslim conceptions". ${ }^{235}$ How far the codification of Moroccan law became in any way more culturally fitting due to Rosen's interventions cannot be judged here, but as in other instances, arguing internationally on the basis of Islamic law and Moroccan heritage or wanting to dispel fearful overreaction by demonstrations of normalcy was likely not fruitful.

von Schowingen and Schabinger von Schowingen, Mosaiksplitter, 46; Vassel, Berlinische und marokkanische Erlebnisse, 87.

233 Friedrich Rosen, Auswärtiges Amt. Marokkokrise, 301; Stephen Cory, "Breaking the Khaldunian Cycle? The Rise of Sharifianism as the Basis for Political Legitimacy in Early Modern Morocco," North African Studies 13, no. 3 (September 2008): 377-94.

234 Albrecht Mendelssohn Bartholdy and Friedrich Thimme, eds., Die Auswärtige Politik des Deutschen Reiches. 1871-1914 (Berlin: Deutsche Verlagsgesellschaft für Politik und Geschichte, 1928), 151; Edmund Burke III, Prelude to Protectorate in Morocco: Precolonial Protest and Resistance, 1860-1912 (Chicago: Chicago University Press, 1976), 131.

235 Friedrich Rosen to Bernhard von Bülow, 6 May 1907, 1248, Personalakten 12576, PA AA. 
Some German business and colonialist interests benefitted from the range of Rosen's actions, but for the German standing in the European diplomatic system his and the Auswärtiges Amt's Morocco policy was harmful, leading to constant squabbles with France and Britain without having formulated any clear objectives in Morocco, but to be obstinate. Bülow's assertion that Morocco could not be given up as this would endanger Germany's position in the Muslim world was the flip-side of the outrage Rosen encountered for his Muslim-friendly policies amid overrated calls for holy war in Morocco. ${ }^{236}$ In a widely spread wartime article by the long-standing Times correspondent Walter Harris, it read:

The muddiest period of German intrigue was during the years that Dr. Rosen, that astute Orientalist, represented Germany at Tangier... there was no intrigue to which the German Minister did not stoop, no misrepresentation that he was not prepared to make by which he could injure the cause of France and lead the natives to believe that an imminent and successful German intervention was at hand. Dr. Rosen's failure in Morocco was owing to the fact that he intrigued too much. He played the native game less ably than the native himself, and this lost their confidence. The strain of Oriental blood which flowed in his veins prevented his stopping short of notions which the natives would have approved of in their own people, but despised in a European... The Moors regarded Dr. Rosen as one of themselves. ${ }^{237}$

This sort of crossing of boundaries and identification with the other was not tolerated in this particular hegemonic power constellation of the early twentieth century. Successful conquest depended on cultural distance, civilisation superiority and a discourse of asymmetrical difference. Knowledge of "the Orient" or an appreciation of difference did not matter and too close of an association had adverse outcomes.

236 Bernhard von Bülow, Imperial Germany, trans. Marie A. Lewenz (New York: Dodd, Mead and Company, 1915), 100.

237 Rosen’s supposed “Oriental blood” was in reference to Rosen’s Jewish grandfather Ignaz Moscheles. Vassel wrote in his memoirs that an anti-Semitic leaflet defaming Rosen was circulated by "old German nobility" in Morocco and Berlin in the summer of 1906. Walter B. Harris, "German Intrigues in Morocco. The French Zone. Dupers and Duped,” Times, 27 December 1915, 34; "German Plots That Failed," Times of India, 1 February 1916, 6; John Fisher, “An Eagle Whose Wings Are not Always Easy to Clip': Walter Burton Harris," in On the Fringes of Diplomacy: Influences on British Foreign Policy, 1800-1945, John Fisher and Antony Best (London: Routledge, 2011), 155-78; Vassel, Berlinische und marokkanische Erlebnisse, 89; Klaus Vassel, Philipp Vassel. Generalkonsul (1911-1951) (Aachen: Wilhelm Metz, 1977), 9. 


\section{Rosen at the Seam. Openings, Overestimations and Limits of Knowledge in Imperial Politics}

The three sets of political encounters that involved Rosen as a German political agent and cultural intermediary were characteristic for the shift in German foreign policy from a passive approach to an ever more assertive and confrontational Weltpolitik. Elements of Bismarckian balancing and Humboldtian universalist scholarship continued to play a role. The latter benefitted from newfound German proactiveness, while the former showed itself to be unsuitable as an approach to extra-European affairs, contradictory to German businesses entering the international capitalist system and gung-ho German colonialism seeking its national dream abroad.

The sets of negotiations with the three "Oriental” rulers Mozaffar ed-Din Shah, Negus Negesti Menelik II and Sultan 'Abd al-'Aziz IV were conditioned by this development of German foreign affairs, as they were by the standing of the German negotiator Friedrich Rosen in each instance. In 1902 Rosen was a still largely insignificant, but up-and-coming official, requested personally by the Iranian side. In 1905 Rosen had gained stature in the German capital and at the court of Wilhelm II, but was still publicly largely unknown. His appointment to travel to the politically insignificant Ethiopia was also not an expression of appreciation or arising out of concrete knowledge about the Horn of Africa, but a pragmatic move, possibly intended to remove the recalcitrant man from Berlin. By 1906 Rosen had reached the spotlight of press attention, after having been appointed to Tangier in the midst of the Morocco crisis and having ruffled French feathers in the preparatory negotiations for Algeciras in Paris in the summer of 1905. The person and the name Rosen became associated with Germany's Weltpolitik policy.

The conditions and ambitions on the sides of Iran, Ethiopia and Morocco were in some regards comparable. They were all extra-European countries struggling with the European world order and imperialist expansion on its borders. The key difference was Ethiopia's real independence and its growing power as a nationalist-modernist empire, while the regimes in Iran and Morocco were rapidly losing room for manoeuvre, with every action leading to more debilitating consequences amid European imperial penetration. The German state knew that its attractiveness abroad was next to its scientific progress its military might. Outwardly, the Gardes du Corps represented this German military might, but as Krupp's fingerprints were noticeable in all three sets of negotiations one is re- 
minded that $80 \%$ of Krupp's armaments were sold outside Germany. ${ }^{238}$ Germany appeared for all three countries as a potential European partner, who would not threaten but rather bolster territorial integrity. Moreover, Germany was an attractive model to emulate. This was a connected world. People in Morocco, Iran and Ethiopia knew that German lands was also conquered in the past and had been unified through diplomacy and military means by Bismarck and then emerged as a powerful state on the world stage. The appeals of these "Oriental" countries to Germany were then also underpinned with the argument that surely the Germans could understand their plight.

These conditions formed the framework of these negotiation situations. The Shah's visit to Potsdam and Berlin in 1902 came as an attempt to interest Germany in Iranian affairs and prop up the Shah's regime, as its independence was already heavily impaired. The German government was well-aware of Iran's situation and wanted little from the country. A friendly business environment would be enough, as all other involvement or commitment were due to alienate England and Russia. Consequently, substantial negotiations were blocked from the outset and did not come about despite repeated Iranian propositions. The Sondergesandtschaft to Ethiopia in early 1905 signified a low-level shift of German foreign policy, following the impetus of Alldeutsche and business lobbying after years of unrequited Ethiopian overtures. Rosen's mission was in a way a masterpiece of Germany's non-interventionist internationalisation strategy with free trade at its centre, aimed at mutually beneficial economic development and cultural collaboration. Constrained by surrounding European interests, Ethiopia's surge in power was crucial to enabling this collaboration, and the negotiations with Germany resulted in the consolidation of Menelik's power. In Fez the diametrically opposite was the case: the Moroccan sultan desperately needed Germany for survival, while Germany's foreign policy of international economic expansion, placating of nationalists and general indecisiveness amid bureaucratic and court infighting motivated repeating initiatives in Morocco that were less aimed at the reinvigoration of the Sharifian empire - despite all Alldeutsche bravado over the supposed strengthening of Morocco through the injection of "Deutschtum" (Germanness) ${ }^{239}$ - but rather hovered between pursuing German business and colonial interests and preventing France from completing its take-over. The results of the negotiations were as far-reaching as they were short-lived, as the Morocco-German rapprochement did not strengthen either side and served the already preponderant French power as ammunition for at-

238 Petersson, "Das Kaiserreich in Prozessen ökonomischer Globalisierung," 60-61. 239 "Parteien und Parteiführer in Marokko." 
tacking both Morocco and Germany and mobilising French nationalist fervour. For German foreign policy, a continued low-level alignment with Raisuli may have been more effective and from an anti-imperial angle for the interests of Morocco as a whole likely more beneficial, but German business and colonial interests were served more by collaborating with 'Abd al-'Aziz, even if none of these ventures were sustainable.

The political, cultural and Orientalist knowledge bundled in Friedrich Rosen had everything and nothing to do with these three sets of diplomatic encounters. During the visit of Mozaffar ed-Din and Amin as-Sultan to Germany, Rosen could draw in full on his knowledge tool-box. Conversant in language and social codes, aware of political conditions and landscapes in Iran, even on good terms with the key actors, Rosen was hemmed in by having to prove his loyalty and mettle with only a year in on the job as Orient councillor at the Auswärtiges Amt. Rosen's concern over the pious Muslim Mozaffar ed-Din taking offense by talk of excavations of cultures from the jahili period may have been an outgrowth of Rosen's captivation with Iran's Islamic heritage or a falsely pleaded concern to keep Germany out of becoming bogged down in Iran. In either case it cost the Iranian delegation the chance to interest Wilhelm personally, despite it being questionable if the Kaiser's interest in excavations would have completely reversed all other considerations that advised restraint. After the initial snub of accommodating the Shah in the Orangerie had been skilfully interpreted by Rosen into charming both sides, the visit was generally seen as successful for the Germans as they reached their economic goals and the company of the Shah was not too awkward, and for the Iranians in comparison to the rebuke by the British a few weeks later and the recognition extended from one royal house to another. Able to present himself as a skilful mediator of German and Iranian, or German and Oriental politics, the primary beneficiary of the three days in 1902 was Rosen's career.

Despite Rosen's near complete lack of previous engagement with anyone or anything Ethiopian, the first months of 1905 saw him at peak performance. Using his Arabic skills, bringing and keeping together a diverse delegation, Rosen was aware of his lack of understanding and keen on learning, a spirit central to the mission. At Addis Ababa, far removed from German key interests and with little German colonialist activity, Rosen managed to defuse and isolate the irascible Holtz, working within the limits of the diplomatically achievable and showcasing his Orientalist knowledge by orchestrating an archaeological mission of benefit to the Ethiopian ruler's crafting of national legitimacy and German scholars.

As the political goals he pursued for the German government became more ambitious in the aftermath of the Morocco crisis, Rosen's actions in Morocco in the fall of 1906 came under global scrutiny. Matters of knowledge were less im- 
portant, even as he had again been appointed with the express purpose of having an Orient specialist in Tangier. Learning of his appointment several weeks after the fact through the press in far-away Ethiopia allows for speculating of whether he was not honourably removed from Berlin, rather than posted to Tangier as the best authority in Moroccan affairs. His prior exposure to Morocco was minimal, even as his interest in Sharifian history, culture and sciences was genuine. The fearlessness he put on display was not courageous or reckless, but more firmly rooted in fact than most of the sensationalist press reports at the time. Rosen lacked reliable and powerful partners among Moroccans and Europeans, overestimating what he could do with the help of German colonialist circles and operating in an environment in which make-believe and campaigns were more significant than more profound forms of knowledge and understanding. This was also due to Moroccan culture and Islamic civilisation being devalued in the dominant press and diplomatic discourse. The negotiations in Morocco were buttressed by a German pronouncement of friendliness to Islam, embodied by the Arabic-speaking German envoy, and symbolically reciprocated by the Moroccan sultan with the gift of the green saddle for the German rescuers. Despite this symbolism, the negotiations had little to do with knowledge but with a concrete power situation, in which the Moroccans were entirely reliant on the Germans. Rosen's observations of the stagnation of Morocco's Islamic civilisation as well as European penetration causing the decline of the country and its culture went largely ignored in Berlin, resulting in no real learning effect either. The sight of his closeness to Muslim Moroccans did, however, serve European actors as a smokescreen for undermining the German envoy in Morocco and Germany internationally. The combination of Islamophobia and antisemitism into Orient-hatred, as was levelled against the person of Rosen, speaks volumes about how the willingness to learn and engage with the foreign could also be turned on its head and used in the service of politics geared towards domination rather than collaboration.

All three instances showed that the application of knowledge in the form put forth by the SOS could play a significant role, particularly when power relations were not antagonistic or constrained by external factors. Equally, knowledge could be applied for manipulation, its non-application could shut down policy-options and outcomes of negotiations could be reinterpreted by outside forces to the extent that hard-won agreements became undone or irrelevant. In such situations too much understanding could push a diplomat into a corner of over-sympathising with the other, or being perceived as such, which could result in the othering of the diplomat himself.

On a personal level, observing the decline of the once proud cradle of Islamic learning at Fez strengthened Rosen's belief in the inevitability of the decline of 
the Muslim world. This conception also framed the way the prominent Orient expert of the German foreign policy apparatus conceived of Germany's place and possibilities in international affairs. The experience of his Fez achievements leading to policy failure, fighting on lost position without backing from Berlin and his sense of isolation in Tangier would in the following years reinforce Rosen's scepticism towards the ability of the Auswärtiges Amt to navigate in world affairs. Leaving Morocco in 1910 also marked Rosen's departure from Orient politics. In his following posts in Romania, Portugal and the Netherlands his Orient expertise no longer played a prominent role. 